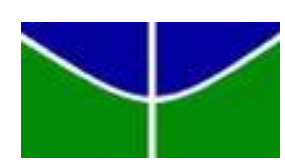

Universidade de Brasília - UnB

Faculdade de Tecnologia - FT

Departamento de Engenharia Elétrica - ENE

Dissertação de Mestrado

\title{
MODELO HÍBRIDO DE APRENDIZAGEM \\ UTILIZANDO A PLATAFORMA ARDUINO APLICADO AO \\ ENSINO TECNOLÓGICO DE INFORMÁTICA
}

Allisson Lopes de Oliveira 
Universidade de Brasília - UnB

Faculdade de Tecnologia - FT

Departamento de Engenharia Elétrica - ENE

\title{
ALLISSON LOPES DE OLIVEIRA \\ MODELO HÍBRIDO DE APRENDIZAGEM \\ UTILIZANDO A PLATAFORMA ARDUINO APLICADO AO ENSINO TECNOLÓGICO DE INFORMÁTICA
}

\begin{abstract}
Dissertação de Mestrado submetida ao Departamento de Engenharia Elétrica da Faculdade de Tecnologia da Universidade de Brasília, como parte dos requisitos necessários para obtenção do título de Mestre em Engenharia Elétrica.
\end{abstract}

Orientador: Prof. Dr. Humberto Abdalla Júnior.

Banca Examinadora:

Prof. Dr. Humberto Abdalla Júnior - Orientador

ENE/FT/UnB

Prof. Dr. João Melo - Membro Interno

$\mathrm{ENP} / \mathrm{FT} / \mathrm{UnB}$

Prof. Dr. Rogério Mendes Murta - Membro Externo

IFNMG

Prof. Dr. - Suplente

ENE/FT/UnB

Brasília, de de 2015. 


\section{FICHA CATALOGRÁFICA}

\section{OLIVEIRA, ALLISSON LOPES}

Modelo Híbrido de Aprendizagem Utilizando a Plataforma Arduino no Ensino

Tecnológico de Informática [Distrito Federal] 2015.

xiv, $\quad \mathrm{mm}(\mathrm{ENE} / \mathrm{FT} / \mathrm{UnB}$, Mestre, Dissertação de Mestrado - Universidade de

Brasília. Faculdade de Tecnologia.

Departamento de Engenharia Elétrica
1. Aprendizagem Híbrida
2. Plataforma Arduino
3. Metodologias de Aprendizagem
4. Ferramentas Tecnológicas
I. ENE/FT/UnB
II. Título(série)

\section{REFERÊNCIA BIBLIOGRÁFICA}

OLIVEIRA, A. L. (2015). Modelo Híbrido de Aprendizagem Utilizando a Plataforma Arduino Aplicado ao Ensino Tecnológico de Informática Dissertação de Mestrado em Engenharia Elétrica, Publicação PPGENE.DM-, Departamento de Engenharia Elétrica, Universidade de Brasília, Brasília, DF,123p.

\section{CESSÃO DE DIREITOS}

AUTOR: Allisson Lopes de Oliveira.

TÍTULO: Modelo Híbrido de Aprendizagem Utilizando a Plataforma Arduino Aplicado ao Ensino Tecnológico de Informática.

GRAU: Mestre

ANO: 2015

É concedida à Universidade de Brasília permissão para reproduzir cópias desta dissertação de mestrado e para emprestar ou vender tais cópias somente para propósitos acadêmicos e científicos. $\mathrm{O}$ autor reserva outros direitos de publicação e nenhuma parte dessa dissertação de mestrado pode ser reproduzida sem autorização por escrito do autor.

Allisson Lopes de Oliveira

Rua Antônio Cordeiro ${ }^{\circ}$ 86, Planalto.

38.680-000 Arinos - MG - Brasil. 
Aos meus pais, Pedro Cordeiro e Eva Lopes, que investiram e confiaram em mim, sem nunca deixarem me faltar amor para que pudesse realizar esse sonho. 


\section{AGRADECIMENTOS}

Primeiramente a Deus pelo dom da vida e pelo sonho que plantou em mim, dando-me forças para realiza-los. A Ele à honra, à glória e o louvor. À Virgem Maria, pela intercessão.

Aos melhores pais do mundo, Pedro Cordeiro e Eva Lopes que me deram a vida e me ensinaram a vivê-la com dignidade, iluminando os caminhos obscuros com afeto e dedicação, para que os trilhasse sem medo e cheio de esperança, o meu agradecimento.

Ao experiente e competente, Prof. Dr. Humberto Abdalla Júnior, orientador cuja experiência e postura acadêmica são um exemplo para mim. Agradeço a ele, o incentivo, apoio, paciência, ensinamentos e incansável dedicação que recebi ao longo deste mestrado.

Aos professores da UNB - Faculdade de Tecnologia - Departamento de Engenharia Elétrica pela colaboração e apoio no programa: Adolfo Bauchspiess, Adson Ferreira Rocha, Alexandre Ricardo Soares Romariz, Francisco Damasceno Freitas, Fabiano Araújo Soares, Franklin Costa e Silva, Ivan Marques de Toledo Camargo, João Yoshiyuki Ishihara, Kleber Melo e Silva, Leonardo R. A. X. Menezes, Marco Aurélio Gonçalves de Oliveira, Rafael Amaral Shayani. Agradeço muito pelos ensinamentos e experiência compartilhada.

A todos os colegas de mestrado UNB, pela ajuda, colaboração e apoio no cumprimento dos créditos do programa. Agradeço pelos momentos alegres que passamos juntos.

Ao Instituto Federal de Educação, Ciência e Tecnologia do Norte de Minas Gerais (IFNMG), Campus Arinos pelo apoio e liberação para realização das pesquisas.

A PROPPI (Pró - Reitoria de Pesquisa, Pós-Graduação e Inovação) do IFNMG, pelo incentivo no Programa de Bolsas para Qualificação dos Servidores (PBQS), muito obrigado.

A todos os familiares e amigos que me apoiaram e acreditaram nesta grande conquista.

Todos vocês são responsáveis por este momento tão marcante. Obrigado pela compreensão, pelo amor que me fez mais forte, fazendo-me entender que sou capaz de ir mais além. A todos: MUITO OBRIGADO. 


\title{
RESUMO \\ MODELO HÍBRIDO DE APRENIZAGEM UTILIZANDO A PLATAFORMA ARDUINO
}

\author{
Autor: Allisson Lopes de Oliveira \\ Orientador: Humberto Abdalla Júnior \\ Programação de Pós-graduação em Engenharia Elétrica \\ Brasília, novembro de 2015.
}

Esta dissertação descreve um modelo Híbrido de Aprendizagem utilizando a Plataforma Arduino para o "Curso Técnico em Informática", do IFNMG - Instituto Federal do Norte de Minas Gerais - Campus Arinos. Esta metodologia foi aplicada na disciplina de programação WEB, no $2^{\circ}$ e $3^{\circ}$ trimestre de 2014 . O modelo de ensino proposto associa aulas teóricas, práticas e projetos. Tendo como ideia central a avaliação qualitativa a partir do desempenho da experiência, a dissertação é iniciada por uma radiografia sobre o ensino tecnológico no Brasil. Em seguida são retratadas as metodologias de aprendizagem, educação tradicional, aprendizagem colaborativa e aprendizagem híbrida. No decorrer da dissertação são apresentadas as formas de desenvolvimento das atividades, o planejamento e a implementação da Plataforma Arduino. A Plataforma Arduino se enquadra nos objetivos traçados, no caso o ensino tecnológico em instituições públicas de ensino, em função de ser uma moderna plataforma de programação, de baixo custo e de fácil programação. Por meio dos resultados obtidos a partir das avaliações de aprendizagem realizadas durante a disciplina, foi possível avaliar o desenvolvimento de competências transversais, o grau de envolvimento e percepção dos alunos, o conhecimento técnico e a familiaridade no uso da plataforma Arduino.

Palavras-Chave: Aprendizagem Híbrida, Teorias da Aprendizagem, Plataforma Arduino. 


\title{
ABSTRACT \\ HYBRID MODEL OF LEARNING USING THE ARDUINO PLATFORM
}

\author{
Author: Allisson Lopes de Oliveira \\ Advisor: Humberto Abdalla Junior \\ Graduate Program in Electrial Engineering \\ Brasília, November 2015.
}

This paper describes a hybrid learning model using the Arduino platform for the "Technical Course in Information Technology", the IFNMG - North Instituto Federal de Minas Gerais Arinos Campus. This methodology was applied to the WEB programming discipline in the 2nd and 3rd quarter of 2014. The teaching model combines lectures, practices and projects. With the central idea qualitative evaluation from the performance experience, the work is initiated by an X-ray on technological education in Brazil. Then they are portrayed the learning methodologies, traditional education, collaborative learning and hybrid learning. During the dissertation presents the forms of development activities, planning and implementation of the Arduino platform. The Arduino platform fits the objectives outlined in case the technological education in public education, in terms of being a modern programming platform, cost effective and easy to program. Through the results obtained from the learning assessments undertaken during the course, it was possible to evaluate the development of soft skills, the level of involvement and perception of students, technical knowledge and familiarity in using the Arduino platform.

Keywords: Blended Learning, Learnig Theories, Arduino platform. 


\section{SUMÁRIO}

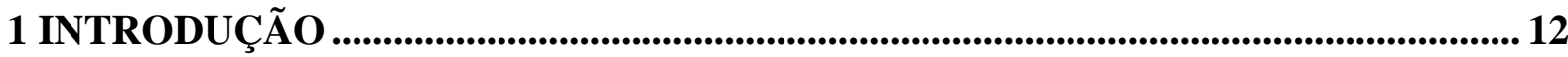

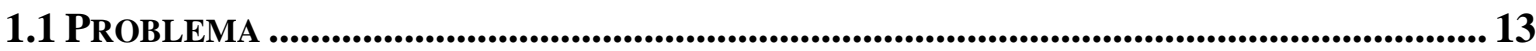

1.2 OBJETIVOS .................................................................................................................. 14

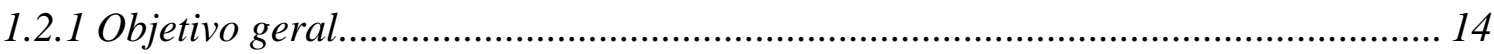

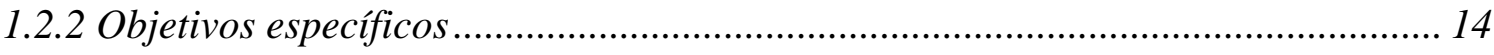

1.3 HIPÓTESE ................................................................................................................................ 14

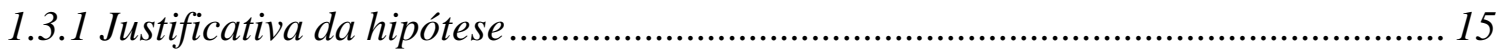

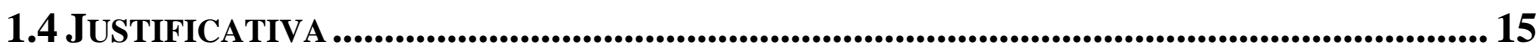

1.5 ESTRUTURA DO ESTUDO......................................................................................................... 15

2 O ENSINO TECNOLÓGICO NO BRASIL ..................................................................16

2.1 EdUCAÇÃo PROFISSIONAL ........................................................................................... 13

2.2 CRIAÇÃO DA REDE FEDERAL ............................................................................................... 13

2.2.1 Os novos desafios da Rede Federal .................................................................... 22

2.2 Historico do InStituto Federal do NORTE de Minas Gerais ............................... 25

2.3.1 Historico do IFNMG, Campus Arinos $(M G)$....................................................... 27

3 MODELOS PEDAGÓGICOS DE APRENDIZADO …….............................................30

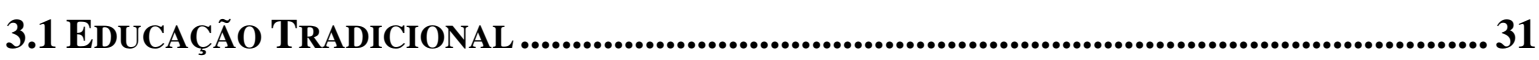

3.2 APRENDIZAGEM COLABORATIVA .............................................................................34

3.2.1 Embasamento Téorico da Aprendizagem Colaborativa ………………………….... 36

3.2.1.1 Epistemologia Génetiva de Piaget ..................................................................... 37

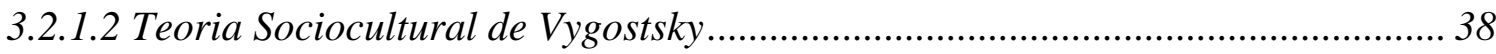

3.2.1.3 Teoria do Construcionismo - Seymour Papert ……………………………….... 40

3.3 APRENDIZAGEM HÍBRIDA.................................................................................................... 42

3.3.1 Concepção do Modelo Híbrido de Aprendizagem ................................................. 44 4 INCLUSÃO DA FERRAMENTA ARDUÍNO COMO ESTRATÉGIA PEDAGÓGICA 49

4.1 RADIOGRAFIA DO ENSINO .............................................................................................. 49

4.2 HISTORICO DA PLATAFORMA ARDUINO ........................................................................51

4.3 PlatAFoRMA ARDUINO .....................................................................................................5 52

4.4 TIPOS DE ARDUINO ....................................................................................................53

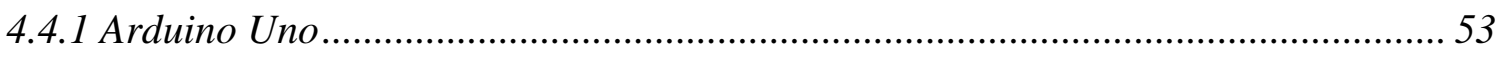

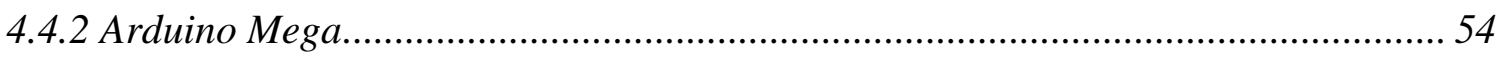




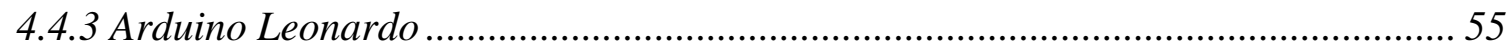

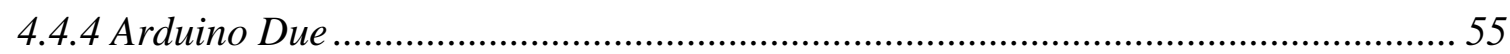

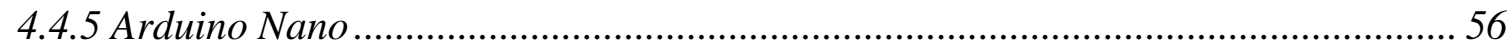

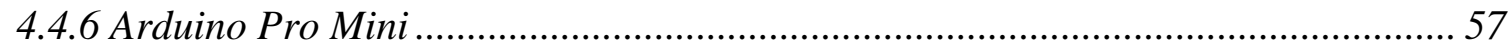

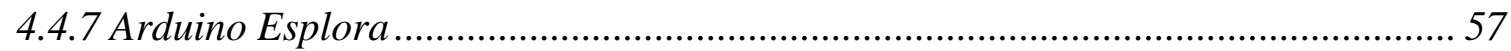

4.5 AMBIENTE DE DESENVOLVIMENTO Do ARDUINO ......................................................58

5 IMPLANTAÇÃO DO BLENDED LEARNING NA DISCIPLINA WEB II ................ 61

5.1 A Disciplina WEB Ministrada DE Forma Tradicional ...................................... 61

5.2 IdentificaÇão do Perfil do Aluno Para A IMPlataÇão do BL.......................... 63

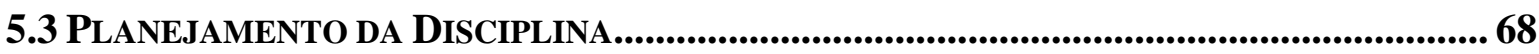

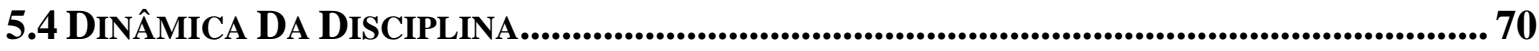

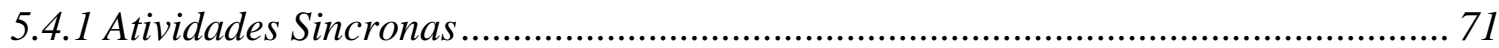

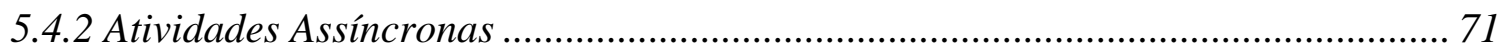

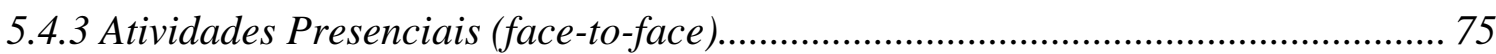

5.5 REALIZAÇÃo do PROJETO ........................................................................................ 76

5.6 ApresentaÇão dos Projetos na Semana NaCional de CiênCia e TeCnologia82

5.7 AVALIAÇÃO DO DESEMPENHO DOS ALUNOS NA DISCIPLINA .........................................93

6 RESULTADOS OBTIDOS NA IMPLANTAÇÃO DA PLATAFORMA ARDUÍNO

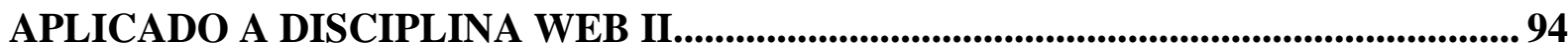

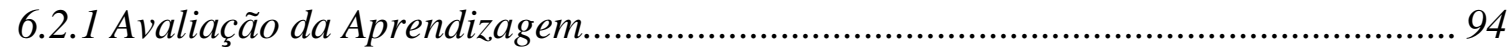

6.2.2 Diagnóstico do Desempenho da Experiência ........................................................ 95

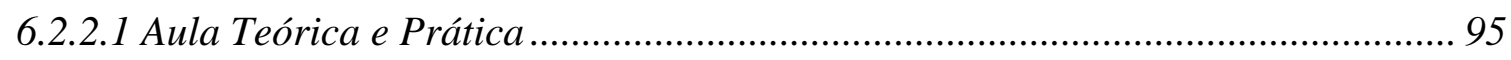

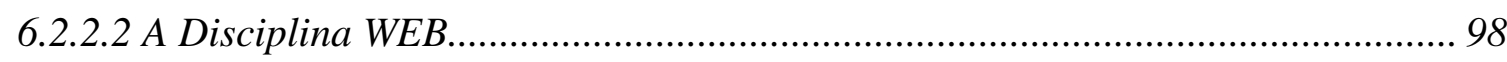

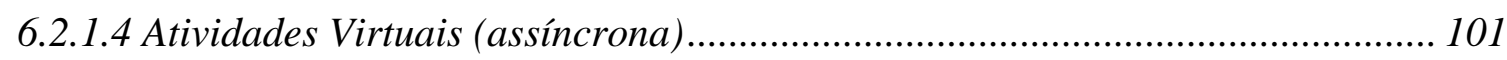

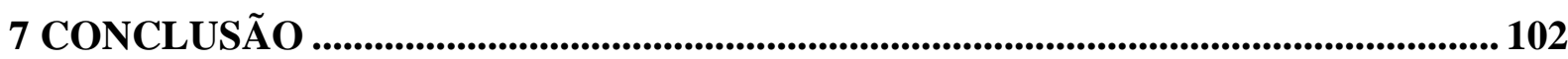

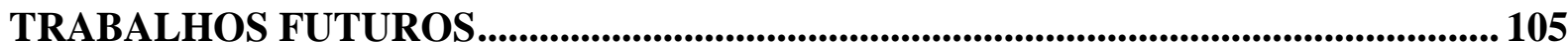

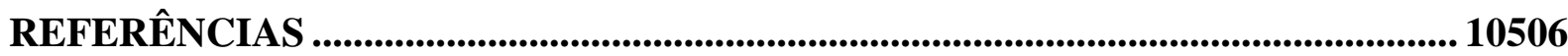

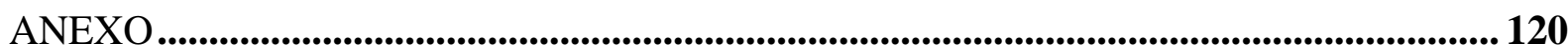

A - TRAJETóRIA DA EdUCAÇÃo FedERAL E TECNOLÓGICA NO BRASIL.............................. 131

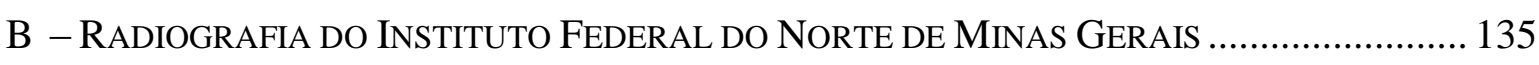

C - Alunos Matriculados EM 2014, IFNMG, IFNMG - CAMPUS ARINOS .................... 137

D - Os PrinciPais Modelos Oficiais da Plataforma ARduino.................................. 139

E - FormulÁRIO DE AVALIAÇÃo DA DisciPLINA: WEB II ................................................. 13 


\section{ÍNDICE DE QUADROS}

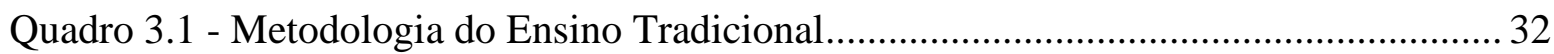

Quadro 3.2 - Comparativo do ensino tradicional e abordagem colaborativa....................... 35

Quadro 3.1 - Atividades dos modos síncrono, síncrono virtual e assíncrono ....................... 45

Quadro 5.1 - Questionário sobre a radiografia dos alunos ............................................... 63

Quadro 5.2 - Requisitos básicos no desenvolvimento dos Módulos................................... 69

\section{ÍNDICE DE TABELA}

Tabela 4.1 - Ementa da disciplina WEB II ............................................................. 49

Tabela 5.1 - Conteúdo programático e carga horária da disciplina..................................... 60

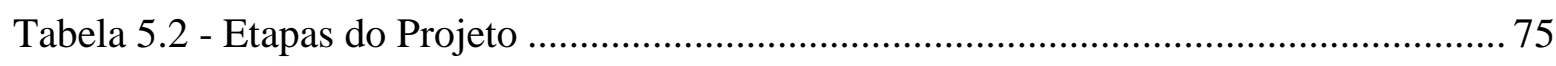

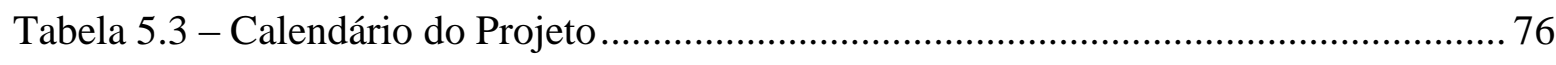

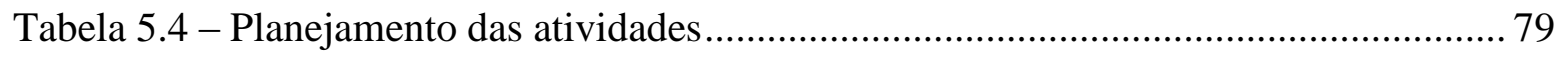

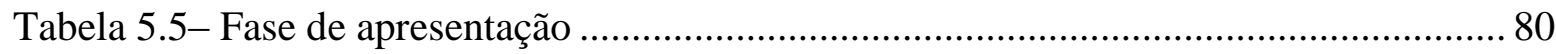




\section{LISTA DE FIGURAS}

\begin{tabular}{|c|c|c|}
\hline Figura 2.1 & Divisão Geopolítica & 17 \\
\hline Figura 2.2 & Expansão da Rede Federal até 2010 & 22 \\
\hline Figura 2.3 & Cenário da Rede Federal & 27 \\
\hline Figura 2.4 & $\begin{array}{l}\text { Distribuição dos Campus do Instituto Federal de Educação, } \\
\text { Ciência e Tecnologia do Norte de Minas Gerais. Fonte: } \\
\text { (IFNMG, 2010) }\end{array}$ & 29 \\
\hline Figura 2.5 & Mapa de Arinos & 32 \\
\hline Figura 3.1 & Os três principais tipos de modelos pedagógicos & 36 \\
\hline Figura 3.2 & Quatro pilares da Aprendizagem colaborativa & 42 \\
\hline Figura 3.3 & Mapa Conceitual do trabalho de Piaget & 45 \\
\hline Figura 3.4 & Principais pontos da Teoria Sociocultural de Vygostsky & 46 \\
\hline Figura 3.5 & Mapa Conceitual da Teoria Sociocultural de Vigotski & 47 \\
\hline Figura 3.6 & A filosofia Construcionista & 48 \\
\hline Figura 3.7 & $\begin{array}{l}\text { Domínios básicos de aquisição do conhecimento utilizados por } \\
\text { Bloom }\end{array}$ & 49 \\
\hline Figura 3.8 & Taxonomia de Bloom & 50 \\
\hline Figura 3.9 & Mapa dos Componentes do Blended Learning. & 52 \\
\hline Figura 3.10 & $\begin{array}{l}\text { Procedimento para a escolha do modo de aprendizagem a ser } \\
\text { utilizado }\end{array}$ & 54 \\
\hline Figura 4.1 & Modelo de Aprendizagem Híbrida proposto & 56 \\
\hline Figura 4.2 & Arduino Uno & 61 \\
\hline Figura 4.3 & Arduino Mega ADK & 61 \\
\hline Figura 4.4 & Arduino Leonardo & 62 \\
\hline Figura 4.5 & Arduino Due & 63 \\
\hline Figura 4.6 & Arduino Nano & 63 \\
\hline Figura 4.7 & Arduino Pro Mini & 64 \\
\hline Figura 4.8 & Arduino Esplora & 65 \\
\hline Figura 4.9 & Led ligado a placa Arduino & 66 \\
\hline Figura 4.10 & Esquemático do circuito. & 66 \\
\hline Figura 4.11 & Programação LED & 67 \\
\hline
\end{tabular}




\begin{tabular}{|c|c|c|}
\hline Figura 5.1 & $\begin{array}{l}\text { Conteúdo programático e formas de avaliação antes do Blended } \\
\text { Learning }\end{array}$ & 70 \\
\hline Figura 5.2 & Faixa etária dos alunos & 72 \\
\hline Figura 5.3 & Sexo dos alunos & 72 \\
\hline Figura 5.4 & Experiência no mercado de trabalho & 73 \\
\hline Figura 5.5 & Uso da internet & 73 \\
\hline Figura 5.6 & Ensino aprendizagem em sala de aula & 74 \\
\hline Figura 5.7 & Outros meios de aprendizagem & 74 \\
\hline Figura 5.8 & $\begin{array}{l}\text { Modelo de Aprendizagem Híbrida utilizado na disciplina WEB } \\
\text { II }\end{array}$ & 76 \\
\hline Figura 5.9 & Tela Principal do Moodle da IFMNG & 78 \\
\hline Figura 5.10 & $\begin{array}{l}\text { Ferramentas Tecnológicas utilizadas nas atividades virtuias } \\
\text { assincronas }\end{array}$ & 79 \\
\hline Figura 5.11 & Atividades Assincronas feitas através do Moodle. & 80 \\
\hline Figura 5.12 & Fórum da disciplina de Programação WEB & 80 \\
\hline Figura 5.13 & WhatsApp & 83 \\
\hline Figura 5.14 & Formação de equipe & 86 \\
\hline Figura 5.15 & Etapas do projeto & 89 \\
\hline Figura 5.16 & Fases do Projeto & 90 \\
\hline Figura 5.17 & Código de robô sonoro & 92 \\
\hline Figura 5.18 & Robô Sonoro & 93 \\
\hline Figura 5.19 & Carrinho & 93 \\
\hline Figura 5.20 & Programação do carrinho & 94 \\
\hline Figura 5.21 & Automação Residencial com Arduino & 96 \\
\hline Figura 5.22 & Página do login utilizada no sistema & 96 \\
\hline Figura 5.23 & Fluxograma de funcionamento Arduino & 97 \\
\hline Figura 5.24 & Comando Cozinha & 98 \\
\hline Figura 5.25 & Comando Sala & 98 \\
\hline Figura 5.26 & Comando Dormitórios & 99 \\
\hline Figura 5.27 & Apresentação do Projeto II na SNCT & 99 \\
\hline Figura 5.28 & Projeto Residencial com Arduino & 100 \\
\hline Figura 5.29 & Projeto Automação Residencial com Arduino & 100 \\
\hline Figura 5.30 & Avaliação da disciplina & 101 \\
\hline
\end{tabular}




\begin{tabular}{|c|c|c|}
\hline Figura 6.1 & Aulas teóricas & 104 \\
\hline Figura 6.2 & Aula prática com Arduino no Laboratório de Informática & 105 \\
\hline Figura 6.3 & Aula prática no Laboratório de Informática & 106 \\
\hline Figura 6.4 & Aprendizado do aluno & 106 \\
\hline Figura 6.5 & $\begin{array}{l}\text { Aspectos: funções, dificuldade no projeto, participação, } \\
\text { liderança, acompanhamento de especialistas e trabalho em } \\
\text { equipe }\end{array}$ & 108 \\
\hline Figura 6.6 & Aplicação da plataforma Arduino & 109 \\
\hline Figura 6.7 & Utilização do AVA para as atividades virtuais & 111 \\
\hline
\end{tabular}

\section{LISTA DE ABREVIATURAS E SIGLAS}

\begin{tabular}{|l|c|l|}
\hline AVA & - & Ambiente Virtual de Aprendizagem \\
\hline CDTI & - & Centro de Desenvolvimento Tecnológico e Inovação \\
\hline CEFET & - & Centro Federal de Educação Tecnológica \\
\hline CPLP & - & Comunidade de Língua Portuguesa \\
\hline EMI & - & Ensino Médio Integrado \\
\hline IBGE & - & Instituto Brasileiro de Geografia e Estatística \\
\hline IDE & & Ambiente de Desenvolvimento do Arduino \\
\hline IFNMG & - & Instituto Federal do Norte de Minas Gerais \\
\hline JK & - & Juscelino Kubitschek \\
\hline LDB & - & Lei de Diretrizes e Bases da Educação Brasileira \\
\hline LDR & & Light Dependent Resistor \\
\hline LED & & Light Emitting Diode \\
\hline LMS & - & Learning Management System \\
\hline MEC & - & Ministério da Educação \\
\hline MERCOSUL & - & Mercado Comum do Sul \\
\hline PDE & - & Plano de Desenvolvimento da Educação \\
\hline PDF & - & Adoble Document Cloud \\
\hline PROEJA & - & Programa Nacional de Integração da Educação Profissional com a \\
\hline PROEP & - & Programa de Expansão da Educação Profissional \\
\hline PRONATEC & - & Programa Nacional de Acesso ao Ensino Técnico e Emprego \\
\hline
\end{tabular}




\begin{tabular}{|l|c|l|}
\hline PWM & & Pulse Width Modulation \\
\hline SETEC & - & Secretaria de Educação Profissional e Tecnológica \\
\hline TIC & - & Tecnologias da Informação e Comunicação \\
\hline UEP & - & Unidade de Educação Profissional \\
\hline UnB & - & Universidade de Brasília \\
\hline USB & & Universal Serial Bus \\
\hline ZDP & & Zona de Desenvolvimento Proximal \\
\hline
\end{tabular}




\section{INTRODUÇÃO}

Com aplicação das Tecnologias da Informação e Comunicação (TIC), a educação tem ampliado seus horizontes, criando novas oportunidades de ensino e se adaptando ao complexo contexto da sociedade contemporânea.

A tecnologia da informação e comunicação (TIC) está cada vez mais presente no ensino. As suas aplicações geram uma cobrança de ajustes e adaptações constantes nos planos políticopedagógicos dos cursos. Para que essas mudanças tenham os efeitos esperados, a escola, os alunos e os professores precisam estar sintonizados com as transformações do mundo globalizado, resultantes da tomada de consciência, pelos homens, da complexidade da interação que possuem com os processos naturais, e do papel do processo educacional na formação de novos cidadãos comprometidos com os princípios básicos da sociedade. [ 1 ]

Refletindo sobre o impacto dessa mudança paradigmática na área educacional, verificase que, na década de 1990, com a explosão comercial da $W E B$, houve um grande crescimento na quantidade de ferramentas educacionais que apoiavam o aprendizado, ainda de forma individualizada e sem o compartilhamento das informações, reproduzindo os modelos pedagógicos tradicionais apoiados nas velhas tecnologias educacionais. [ 2 ]

Surgem então novas ferramentas na área de Tecnologias da Informação Aplicada à Educação que possibilitam aos alunos não estarem limitados em interagir com objetos prontos; eles podem atuar de várias formas no processo de ensino-aprendizagem, como construindo objetos e cenários de aprendizagem, trocando informações, e observando os materiais desenvolvidos.

As novas tecnologias de aprendizagem podem ser implantadas nos cursos técnicos que estão em constante evolução, pois um técnico precisa ter competências para transitar com maior flexibilidade e atender as várias demandas de uma área profissional. O uso dessas tecnologias agregará a esses alunos além das competências profissionais certas competências transversais como, a flexibilidade, a pró-atividade, a capacidade de boa comunicação escrita e falada, o planejamento, a liderança, a capacidade de aprender com o cooperativismo, entre outras.

Utilizar novas tecnologias e novas formas de metodologias de ensino na área de informática propicia um ambiente agradável para o aprendizado, pois nessa área de informática 
o mercado de trabalho e o conhecimento são extremamente dinâmicos necessitando de profissionais com perfis diversificados.

Dessa forma, o desafio de um curso Técnico em Informática é ofertar uma excelente formação na área ao estudante, levando em consideração ferramentas tecnológicas que propiciem o desenvolvimento de habilidade que leve em conta o perfil do aluno e as diversas formas de aprendizagem.

Uma metodologia de ensino centrada no aluno, utilizando TIC, foi desenvolvida e aplicada no curso Técnico em Informática no Instituto Federal do Norte de Minas Gerais IFNMG, Campus Arinos.

\subsection{PROBLEMA}

Analisando a problemática do curso Técnico em Informática do IFNMG, Campus Arinos, fez-se um diagnóstico dos alunos e professores, quais são os principais agentes do processo ensino-aprendizagem.

Ao refletir sobre o andamento do Curso Técnico em Informática, na modalidade EMI (Ensino Médio Integrado), foram evidenciados alguns problemas referentes à relação professoraluno, dificuldade no ensino aprendizagem, desmotivação e, principalmente o alto índice de evasão. "Os alunos desmotivados estudam muito pouco ou consequentemente, aprendem muito pouco". [ 4 ]

De acordo com os dados da secretária escolar do IFNMG, Campus Arinos, o índice de evasão e retenção dos alunos do curso técnico em Informática chegam a ser $60 \%$ (sessenta por cento) ano letivo.

A forma de ingresso no IFNMG, Campus Arinos é realizado por meio de processo seletivo altamente concorrido, tratando-se de um instituto bem-conceituado em toda região do noroeste e norte de Minas Gerais. É necessário, portanto, identificar os fatores internos que influenciam a desmotivação e consequentemente o insucesso dos alunos na escola.

A secretária escolar do Campus Arinos, aplicou um questionário avaliando os alunos do curso Técnico em Informática a respeito da qualidade do ensino, e, um dos principais fatores encontrados pelos alunos foi assimilação do conteúdo teórico com a prática de laboratório. 
No desenvolvimento da dissertação, foi imprescindível que chegassem ao entendimento de fatores que interferissem na aprendizagem do aluno, nas questões internas e externas, atingindo o processo de construção do conhecimento.

\subsection{OBJETIVOS}

\subsubsection{Objetivo geral}

Aplicar técnicas de Aprendizagem Híbrida utilizando a Plataforma Arduino na disciplina programação $W E B$ do curso Técnico de Informática, no Instituto Federal do Norte de Minas Gerais - Campus Arinos e verificar a sua eficácia no desenvolvimento das competências transversais e profissionais do Técnico em Informática.

\subsubsection{Objetivos específicos}

- Utilizar a Plataforma Arduino como suporte de estratégias de ensino-aprendizagem.

- Proporcionar um maior tempo para disseminação do conhecimento dos alunos, desenvolvendo atividades síncronas e assíncronas.

- Relatar as dificuldades encontradas para a implantação do do Modelo Híbrido de Aprendizagem utilizando a Plataforma Arduino e sugerir novos procedimentos.

- Avaliar as percepções dos principais agentes envolvidos nesse processo, os alunos.

- Avaliar os resultados obtidos na implementação do Modelo Híbrido de Aprendizagem utilizando a Plataforma Arduino através da análise de desempenho da experiência.

\subsection{HIPÓTESE}

Aplicação do Modelo Híbrido de Aprendizagem utilizando a Plataforma Arduino potencializa o aprendizado educacional, ou seja, melhora o desempenho dos alunos. 


\subsubsection{Justificativa da hipótese}

O ensino tradicional prioriza o aprendizado teórico, enquanto aplicação da plataforma Arduino na Aprendizagem Híbrida também contempla aplicação prática e projetos. Dessa forma, tanto as habilidades técnicas quanto as não técnicas podem ser desenvolvidas no decorrer da disciplina.

\subsection{JUSTIFICATIVA}

Existem inúmeras possibilidades de aplicação de ferramentas tecnológicas na educação, e também não é novidade a utilização de metodologias que utilizam aplicativos para o processo de ensino-aprendizagem, todavia, quando analisado de forma efetiva, observa-se que existem pouca utilização de recursos, tais como aplicação da Plataforma Arduino.

A partir da análise desse cenário, surgiu a motivação de aplicar a plataforma Arduino na disciplina Programação WEB do curso Técnico em Informática do IFNMG, Campus Arinos como uma tecnológica que pudesse deixar essa disciplina mais atrativa, uma metodologia para formar alunos com o objetivo de dar continuidade na utilização dessa ferramenta e acompanhar o levantamento das necessidades, desenvolvimento e aplicação de todos os processos com a finalidade de ratificar a dissertação que é possível usar a plataforma Arduino e formar pessoas para trabalharem com essa tecnologia.

A proposta desta dissertação foi aplicar essa plataforma de ensino que agregam ao ensino Tecnológico de Informática, para alunos do curso técnico em informática do IFNMG, Campus Arinos, na faixa etária de 14 a 18 anos, proporcionando ao ensino mobilidade, e ainda, promovendo o desenvolvimento das competências transversais e profissionais gerais do Técnico em Informática.

\subsection{ESTRUTURA DO ESTUDO}


O primeiro capítulo, são apresentados, de forma resumida, a contextualização do tema, juntamente com os objetivos e uma descrição sucinta da estrutura do trabalho.

O segundo capítulo, mostra o histórico sobre a educação profissional no Brasil, uma radiografia sobre o ensino tecnológico, o histórico do Instituto Federal de Educação, Ciência e Tecnologia do Norte de Minas Gerais - Campus Arinos.

O terceiro capítulo, descreve a fundamentação teórica sobre as metodologias de aprendizagem, discorrendo sobre a educação tradicional e aprendizagem colaborativa.

O quarto capítulo, fornece o desenvolvimento da metodologia proposta e o planejamento das atividades.

O quinto capítulo, enfoca a implementação da plataforma Arduino na disciplina de programação do curso Técnico de Informática, dentro da premissa de Aprendizagem Híbrida.

O sexto capítulo, apresenta os resultados obtidos na implantação disciplina. Uma análise do desempenho dos alunos quando defrontados com essa nova metodologia é efetuada. Uma comparação entre a maneira tradicional como a disciplina era ministrada e a atual é realizada, levando em consideração a ótica do aluno.

Finalmente o sétimo capítulo, apresenta as conclusões, os desafios enfrentados e sugestões para futuros trabalhos. Ao final são apresentados as referências bibliográficas e os anexos.

\section{O ENSINO TECNOLÓGICO NO BRASIL}

\subsection{EDUCAÇÃO PROFISSIONAL ANTES DA CRIAÇÃO DA REDE FEDERAL}

A formação do trabalhador no Brasil começou a ser feita desde os tempos mais remotos da colonização, tendo como os primeiros aprendizes de ofícios os Índios e os escravos, e "habituou-se o povo de nossa terra a ver aquela forma de ensino como destinada somente a elementos das mais baixas categorias sociais". [5]

Com o advento do ouro em Minas Gerais, foram criadas as casas de Fundição e de Moeda e com elas a necessidade de um ensino mais especializado, o qual destinava-se ao filho de homens brancos empregados da própria Casa. Pela primeira vez, estabelecia-se uma banca 
examinadora que deveria avaliar as habilidades dos aprendizes adquiridas em um período de cinco a seis anos. Caso fossem aprovados, recebiam uma certidão de aprovação. [6]

Os Centros de Aprendizagem de Ofícios nos Arsenais da Marinha no Brasil, foram criados nesse mesmo tempo, os quais traziam profissionais especializados de Portugal e recrutavam pessoas nas ruas ou recorriam aos chefes de polícia para que enviassem presos que tivessem alguma condição de produzir. [6]

O desenvolvimento tecnológico do Brasil ficou estagnado com a proibição da existência de fábricas em 1785. Isso aconteceu devido à consciência dos portugueses de que "O Brasil é o país mais fértil do mundo em frutos e produção da terra. Os seus habitantes têm por meio da cultura, não só tudo quanto lhes é necessário para o sustento da vida, mais ainda artigos importantíssimos, para fazerem, como fazem, um extenso comércio e navegação. Ora, se a estas incontáveis vantagens reunirem as das indústrias e das artes para o vestuário, luxo e outras comodidades, ficarão os mesmos totalmente independentes da metrópole. É, por conseguinte, de absoluta necessidade acabar com todas as fábricas e manufaturas no Brasil”. [5]

A história da educação profissional no Brasil tem várias experiências registradas nos anos de 1800 com a adoção do modelo de aprendizagem dos ofícios manufatureiros que se destinava ao "amparo" da camada menos privilegiada da sociedade brasileira. As crianças e os jovens eram encaminhadas para casas onde, além da instrução primária, aprendiam ofícios de tipografia, encadernação, alfaiataria, tornearia, carpintaria, sapataria, entre outros. [6]

Com a chegada da família real portuguesa em 1808 e a consequente revogação do referido Alvará, D. João VI cria o Colégio das Fábricas, considerado o primeiro estabelecimento instalado pelo poder público, com o objetivo de atender à educação dos artistas e aprendizes vindos de Portugal. [7]

Em 1889, ao final do período imperial e um ano após a abolição legal do trabalho escravo no país, o número total de fábricas instaladas era de 636 estabelecimentos, com um total de aproximadamente 54 mil trabalhadores, para uma população total de 14 milhões de habitantes, com uma economia acentuadamente agrário-exportadora, com predominância de relações de trabalho rurais pré-capitalistas. [6]

O Presidente do Estado do Rio de Janeiro (como eram chamados os governadores na época), Nilo Peçanha iniciou no Brasil o ensino técnico por meio do Decreto $\mathrm{n}^{\circ} 787$, de 11 de setembro de 1906, criando quatro escolas profissionais naquela unidade federativa: Campos, 
Petrópolis, Niterói, e Paraíba do Sul, sendo as três primeiras, para o ensino de ofícios e a última à aprendizagem agrícola. [6]

O ano de 1906 foi marcado pela consolidação do ensino técnico-industrial no Brasil pelas seguintes ações:

- Realização do "Congresso de Instrução" que apresentou ao Congresso Nacional um projeto de promoção do ensino prático industrial, agrícola e comercial, a ser mantido com o apoio conjunto do Governo da União e dos Estados. O projeto previa a criação de campos e oficinas escolares onde os alunos dos ginásios seriam habilitados, como aprendizes, no manuseio de instrumentos de trabalho.

- $\quad$ A Comissão de Finanças do Senado aumentou a dotação orçamentária para os Estados instituírem escolas técnicas e profissionais elementares sendo criada, na Estrada de Ferro Central do Brasil, a Escola Prática de Aprendizes das Oficinas do Engenho de Dentro, no Rio de Janeiro.

- Declaração do Presidente da República, Afonso Pena, em seu discurso de posse, no dia 15 de novembro de 1906: “A criação e multiplicação de institutos de ensino técnico e profissional muito podem contribuir também para o progresso das indústrias, proporcionando-lhes mestres e operários instruídos e hábeis”.

\section{2 - CRIAÇÃO DA REDE FEDERAL DE EDUCAÇÃO PROFISSIONAL E TECNOLÓGICA}

Com o falecimento de Afonso Pena, em julho de 1909, Nilo Peçanha assume a Presidência do Brasil e assina, em 23 de setembro de 1909, o Decreto $\mathrm{n}^{\mathrm{o}}$ 7.566, criando, inicialmente em diferentes unidades federativas, sob a jurisdição do Ministério dos Negócios da Agricultura, Indústria e Comércio, dezenove "Escolas de Aprendizes Artífices", destinadas ao ensino profissional, primário e gratuito. A figura 2.1 apresenta as dezenove Escolas de Aprendizes Artífices. [6] 


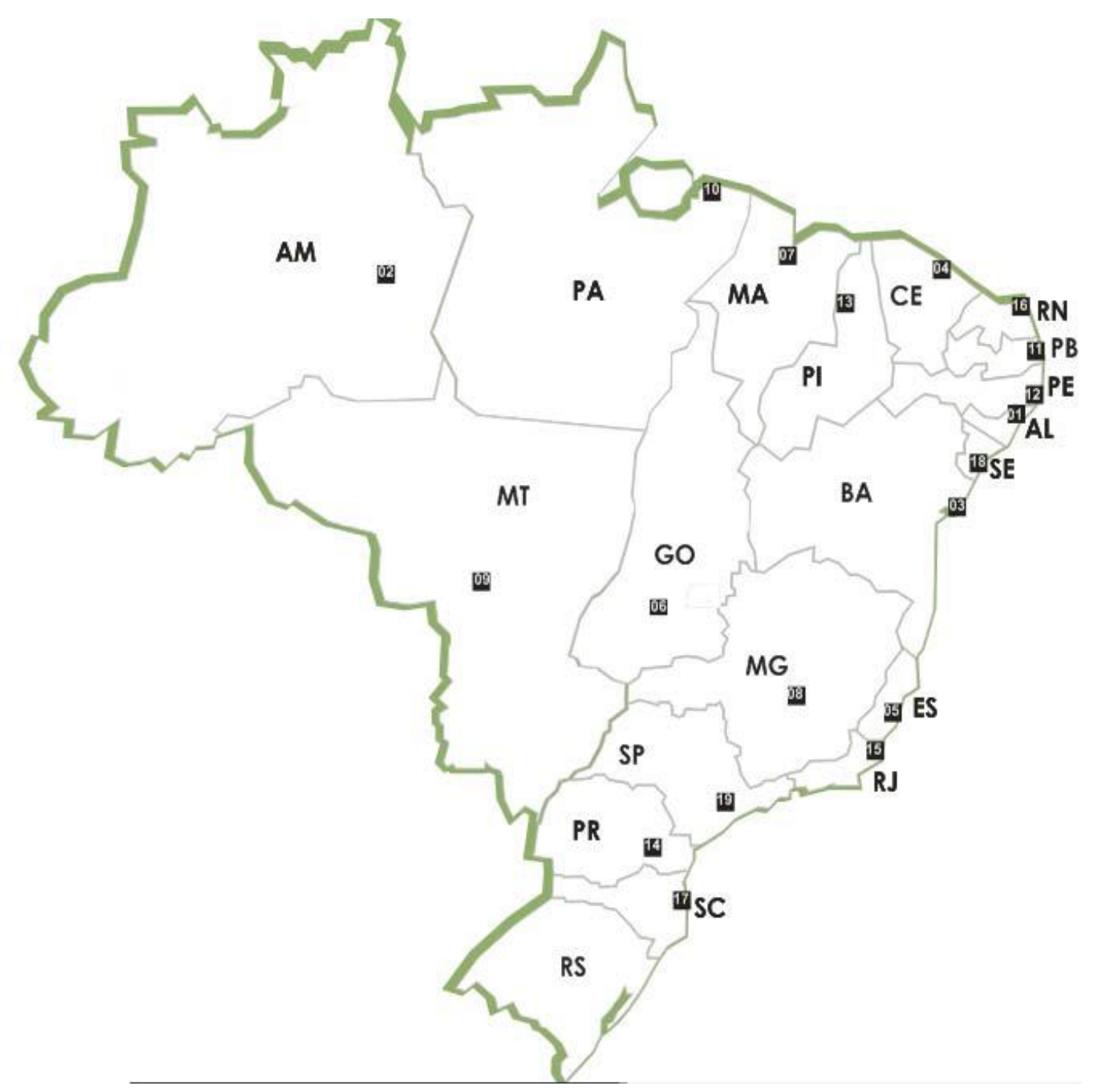

Figura 2.1 - Divisão Geopolítica

Fonte $-[6]$

O Congresso Nacional sancionou em 1927 o Projeto de Fidélis Reis que previa o oferecimento obrigatório do ensino profissional no país. Com a criação, em 14 de novembro de 1930, do Ministério da Educação e Saúde Pública foi estruturada a Inspetoria do Ensino Profissional Técnico, que passava a supervisionar as Escolas de Aprendizes Artífices, antes ligadas ao Ministério da Agricultura. Essa Inspetoria foi transformada, em 1934, em Superintendência do Ensino Profissional. Foi um período de grande expansão do ensino industrial, impulsionada por uma política de criação de novas escolas industriais e introdução de novas especializações nas escolas existentes. [6]

A Constituição brasileira de 1937 foi a primeira a tratar especificamente de ensino técnico, profissional e industrial, estabelecendo no artigo 129: 
“O ensino pré-vocacional e profissional destinado às classes menos favorecidas é, em matéria de educação, o primeiro dever do Estado. Cumpre-lhe dar execução a esse dever, fundando institutos de ensino profissional e subsidiando os de iniciativa dos Estados, dos Municípios e dos indivíduos ou associações particulares e profissionais. É dever das indústrias e dos sindicatos econômicos criar, na esfera de sua especialidade, escolas de aprendizes, destinadas aos filhos de seus operários ou de seus associados. A lei regulará o cumprimento desse dever e os poderes que caberão ao Estado sobre essas escolas, bem como os auxílios, facilidades e subsídios a lhes serem concedidos pelo poder público”. [6]

Assim, em 13 de janeiro de 1937, foi assinada a Lei 378 que transformava as Escolas de Aprendizes e Artífices em Liceus Profissionais, destinados ao ensino profissional, de todos os ramos e graus. Em 1941 vigoraram uma série de leis conhecidas como a "Reforma Capanema" que remodelou todo o ensino no país, e tinha como principais pontos:

- O ensino nas escolas industriais passou a depender de exames de admissão;

- O ingresso nas escolas industriais passou a depender de exames de admissão;

- Os cursos foram divididos em dois níveis, correspondentes aos dois ciclos do novo ensino médio: o primeiro compreendia os cursos básico industrial, artesanal, de aprendizagem e de mestria. O segundo ciclo correspondia ao curso técnico industrial, com três anos de duração e mais um de estágio supervisionado na indústria, e compreendendo várias especialidades.

O Decreto $\mathrm{n}^{\mathrm{o}}$ 4.127, de 25 de fevereiro de 1942 transforma as Escolas de Aprendizes e Artífices em Escolas Industriais e Técnicas, passando a oferecer a formação profissional em nível equivalente ao do secundário. A partir desse ano, inicia-se, formalmente, o processo de vinculação do ensino industrial à estrutura do ensino do país como um todo, uma vez que os alunos formados nos cursos técnicos ficavam autorizados a ingressar no ensino superior em área equivalente à da sua formação. [6]

O governo de Juscelino Kubitschek (1956-1961) traz a marca do aprofundamento da relação entre Estado e economia. Neste período, a indústria automobilística surge como o grande ícone da consolidação da indústria nacional. O Plano de Metas do Governo JK nesses cinco anos prevê investimentos maciços nas áreas de infraestrutura (à produção de energia e ao transporte 
são conferidos $73 \%$ do total dos investimentos). Pela primeira vez contempla-se o setor de educação com $3,4 \%$ do total de investimentos previstos. O objetivo era a formação de profissionais orientados para as metas de desenvolvimento do país. No ano de 1959, as Escolas Industriais e Técnicas são transformadas em autarquias com o nome de Escolas Técnicas Federais. As instituições ganham autonomia didática e de gestão. Com isso, intensificam a formação de técnicos, mão de obra indispensável diante da aceleração do processo de industrialização. [6]

A Lei de Diretrizes e Bases da Educação Brasileira - LDB, nº 5.692, de 11 de agosto de 1971, torna, de maneira compulsória, técnico-profissional, todo currículo do segundo grau. Um novo paradigma se estabelece: formar técnicos sob o regime da urgência. Nesse tempo, as Escolas Técnicas Federais aumentam expressivamente o número de matrículas e implantam novos cursos técnicos. [6]

Em 1978, com a Lei nº 6.545, três Escolas Técnicas Federais (Paraná, Minas Gerais e Rio de Janeiro) são transformadas em Centros Federais de Educação Tecnológica - CEFETs. Esta mudança confere àquelas instituições mais uma atribuição, formar engenheiros de operação e tecnólogos, processo esse que se estende às outras instituições bem mais tarde. [6]

Em 1994 a Lei n ${ }^{\circ}$ 8.948, de 8 de dezembro dispõe sobre a instituição do Sistema Nacional de Educação Tecnológica, transformando, gradativamente, as Escolas Técnicas Federais e as Escolas Agrotécnicas Federais em Centros Federais de Educação Tecnológica - CEFETs, mediante decreto específico para cada instituição e em função de critérios estabelecidos pelo Ministério da Educação, levando em conta as instalações físicas, os laboratórios e equipamentos adequados, as condições técnico-pedagógicas e administrativas, e os recursos humanos e financeiros necessários ao funcionamento de cada centro. [6]

Em 20 de novembro de 1996 foi sancionada a Lei 9.394 considerada como a segunda LDB, que dispõe sobre a Educação Profissional num capítulo separado da Educação Básica, superando enfoques de assistencialismo e de preconceito social contido nas primeiras legislações de educação profissional do país, fazendo uma intervenção social crítica e qualificada para tornar-se um mecanismo para favorecer a inclusão social e democratização dos bens sociais de uma sociedade. Além disso, define o sistema de certificação profissional que permite o reconhecimento das competências adquiridas fora do sistema escolar. [6]

O Decreto 2.208/1997 regulamenta a educação profissional e cria o Programa de Expansão da Educação Profissional - PROEP. Em meio a essas complexas e polêmicas 
transformações da educação profissional de nosso país, retoma-se em 1999 o processo de transformação das Escolas Técnicas Federais em Centros Federais de Educação Tecnológica, iniciado em 1978. [6]

\subsection{3 - Os novos desafios da Rede Federal de Educação Profissional e Tecnológica}

De 1909 a 2002 foram construídas 140 unidades, melhor configurando a Rede Federal de Educação Profissional e Tecnológica brasileira. O Decreto 5.154/2004 permite a integração do ensino técnico de nível médio ao ensino médio. Em 2005, com a publicação da Lei 11.195, ocorre o lançamento da primeira fase do Plano de Expansão da Rede Federal de Educação Profissional e Tecnológica, com a construção de 64 novas unidades de ensino. [6]

Nesse ano ocorreu a transformação do CEFET - Paraná em Universidade Tecnológica Federal do Paraná e primeira universidade especializada nessa modalidade de ensino no Brasil. O Decreto 5.773/2006 dispõe sobre o exercício das funções de regulação, supervisão e avaliação de instituições de educação superior e cursos superiores de graduação e sequencias no sistema federal de ensino. [6]

Em 2006, com o Decreto 5.840 é instituído, no âmbito federal, o Programa Nacional de Integração da Educação Profissional com a Educação de Jovens e Adultos - PROEJA com o ensino fundamental, médio e educação indígena. Ainda no ano de 2006 é lançado o Catálogo Nacional dos Cursos Superiores de Tecnologia para disciplinar as denominações dos cursos oferecidos por instituições de ensino público e privado.

Durante o ano de 2006 a Secretaria de Educação Profissional e Tecnológica - SETEC do Ministério da Educação, em parceria com o Fórum Nacional de Gestores Estaduais de Educação Profissional realizaram conferências em 26 Estados e no Distrito Federal, as quais culminaram, no período de 05 a 08 de novembro de 2006, com a $1^{\text {a }}$ Conferência Nacional de Educação Profissional e Tecnológica, marco importante na educação brasileira, com a participação de 2.761 participantes, foi a primeira conferência que o Ministério da Educação realizou em toda a sua história. [6]

Em 2007 há o lançamento da segunda fase do Plano de Expansão da Rede Federal de Educação Profissional e Tecnológica, tendo como meta entregar à população mais 150 novas unidades, perfazendo um total de 354 unidades, até o final de 2010, cobrindo todas as regiões 
do país, oferecendo cursos de qualificação, de ensino técnico, superior e de pós-graduação, sintonizados com as necessidades de desenvolvimento local e regional, figura 2.2. [6]

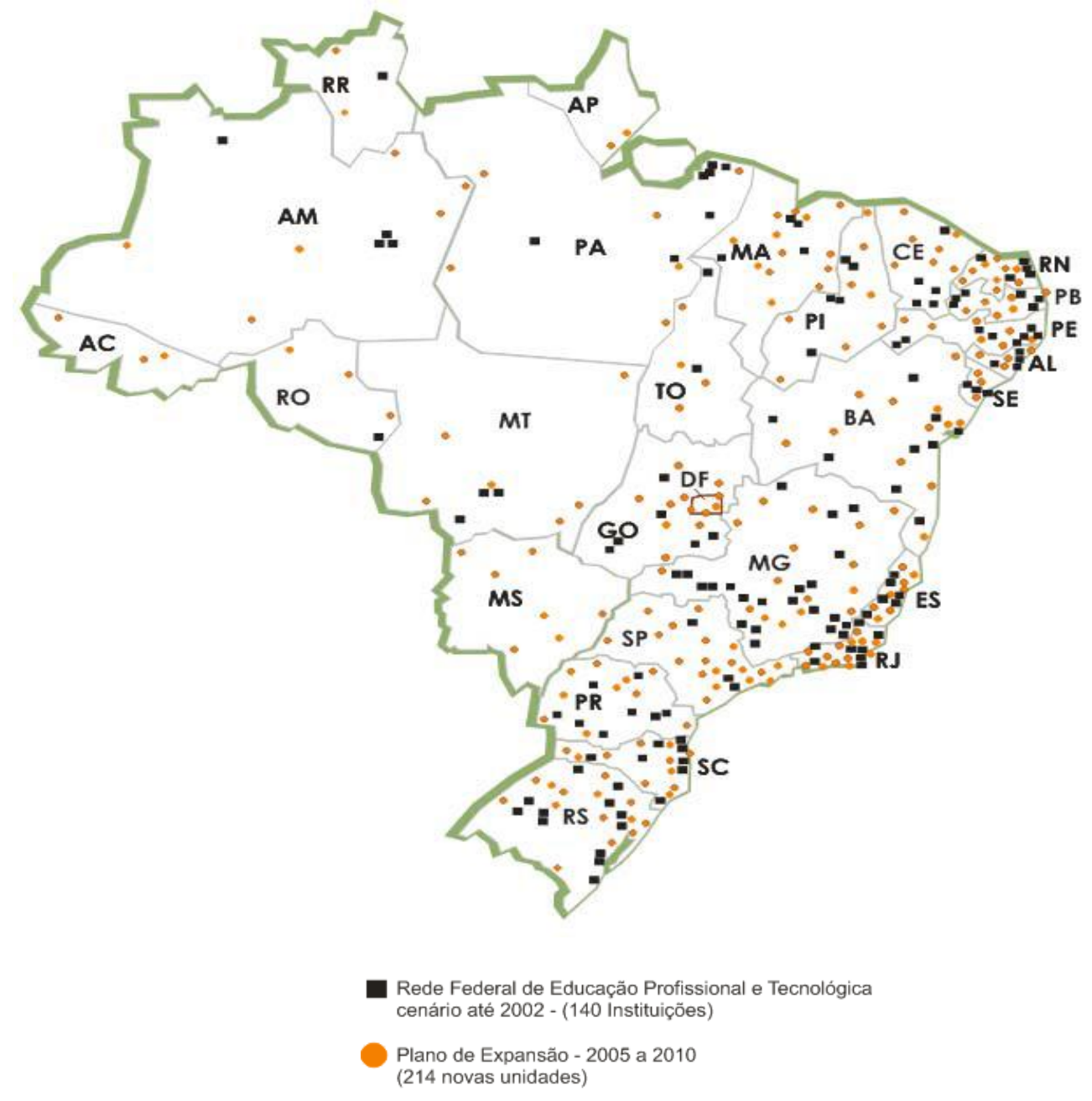

Figura 2.2: Expansão da Rede Federal até 2010

Fonte: [6]

O Catálogo Nacional dos Cursos Técnicos, elaborado durante o ano de 2007, esteve em consulta pública, por seis meses, recebendo críticas e sugestões de toda a sociedade. Em processo de revisão final, entra em vigência ainda no primeiro semestre de 2008, como importante instrumento de divulgação e regulação da oferta de Cursos Técnicos por todo o Brasil. [6]

A educação profissional e tecnológica assume valor estratégico para o desenvolvimento nacional resultante das transformações ao longo das últimas décadas na Rede Federal, cuja visibilidade social apenas recentemente começou a tomar forma com a criação da Universidade Tecnológica Federal do Paraná, com os esforços para a criação dos Institutos Federais de 
Educação, Ciência e Tecnologia, em andamento, e com a intensificação e diversificação das atividades de ensino visando a atender os mais diferenciados públicos nas modalidades: presencial, semipresencial e a distância. [6]

Vale ressaltar que as unidades que formam a Rede Federal de Educação Profissional e Tecnológica desenvolvem projetos de intercâmbio internacional nos países que integram o MERCOSUL, a Comunidade de Língua Portuguesa - CPLP, e outros países como o Canadá. [6]

Além do mais, nos últimos anos tem sido intensa a procura dos países africanos para conhecer a educação profissional e tecnológica do Brasil, a fim de estabelecerem parcerias educacionais, visto que as experiências desenvolvidas na Rede Federal constituem-se em uma referência. A maior parte dessas parcerias visa também projetos de inclusão social da comunidade com a qual a unidade da Rede Federal esteja envolvida, caracterizando, assim, o compromisso com a extensão acadêmica. [6]

Outro aspecto muito importante é a confiança e consequente aproveitamento da mão-de obra qualificada pelas unidades educacionais da Rede, como estagiários ou, posteriormente, funcionários, em empresas como a PETROBRÁS, a Empresa Brasileira de Correios e Telégrafos, Companhia Vale, Grupo Votorantim dentre outras grandes empresas, assim como em outras de pequeno ou médio porte. Isso reflete a busca de parcerias frutíferas entre a Rede e o setor produtivo e a comunidade. [6]

Em 29 de dezembro de 2008 é sancionada a lei ${ }^{\circ} 11.892$ pela qual a Rede Federal de Educação Profissional, Científica e Tecnológica cria os Institutos Federais de Educação, Ciência e Tecnologia.

De acordo com a figura 2.3, o cenário da Rede Federal de Educação Tecnológica aumentou de uma maneira significativa nos últimos 12 (doze) anos. 


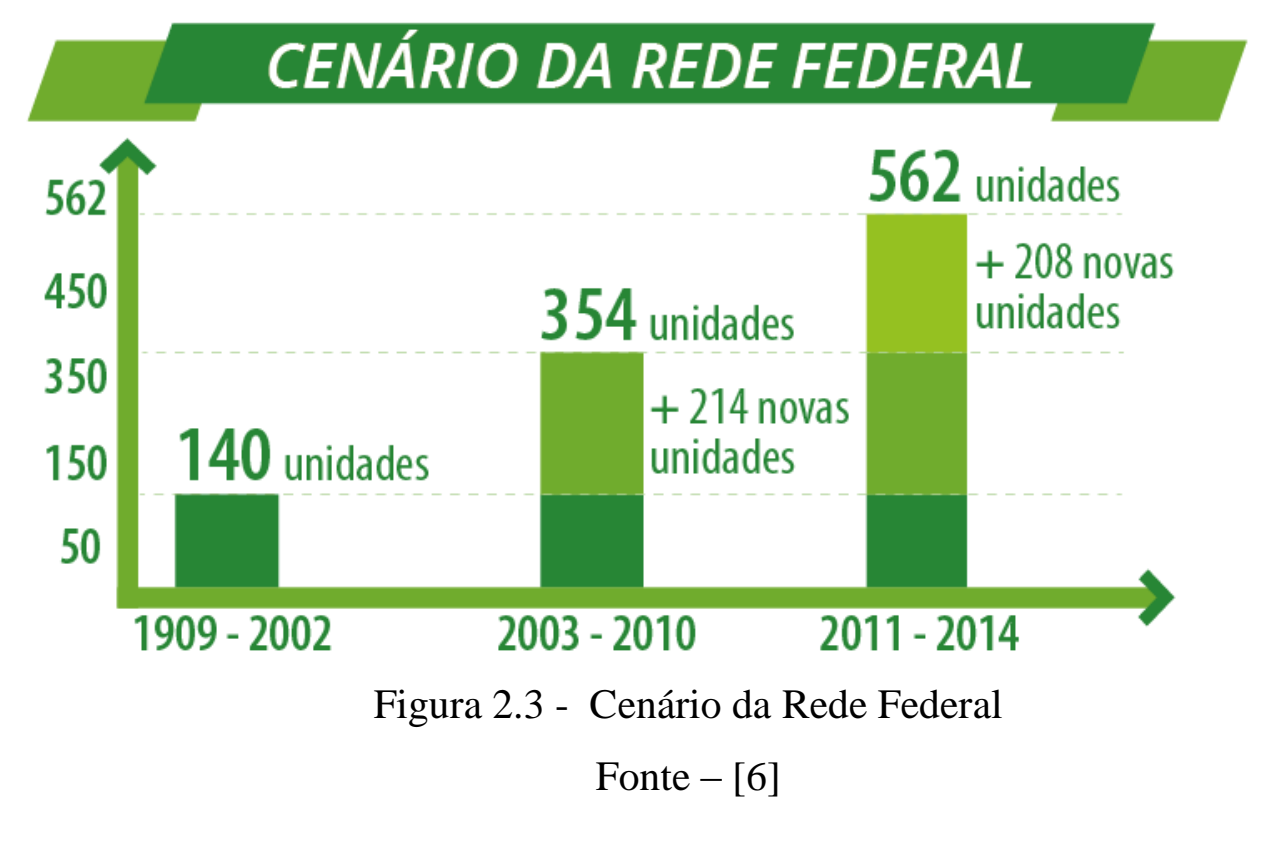

\subsection{HISTÓRICO INSTITUCIONAL DO IFNMG}

Com a publicação da Lei $n^{\circ} 11.892$ no Diário Oficial da União, sancionada pelo presidente Luiz Inácio Lula da Silva, em 29 de dezembro de 2008, foram criados os Institutos Federais de Educação, Ciência e Tecnologia. Os Institutos Federais de Educação, Ciência e Tecnologia são instituições de educação superior, básica e profissional, pluricurriculares e multicâmpus, especializados na oferta de educação profissional e tecnológica nas diferentes modalidades de ensino, com base na conjugação de conhecimentos técnicos e tecnológicos às suas práticas pedagógicas. Os institutos deverão ter forte inserção na área de pesquisa e extensão, visando estimular o desenvolvimento de soluções técnicas e tecnológicas e estendendo seus benefícios à comunidade. [8]

O Instituto Federal do Norte de Minas Gerais (IFNMG) é uma instituição de educação superior, básica e profissional, pluricurricular, multicâmpus e descentralizada, especializada na oferta de educação profissional e tecnológica nas diferentes modalidades de ensino, com base na conjugação de conhecimentos técnicos e tecnológicos com sua prática pedagógica. Sua área de abrangência é constituída por 173 municípios distribuídos em 03 mesorregiões (Norte de Minas, parte do Noroeste e parte do Jequitinhonha), ocupando uma área total de 209.262,579 $\mathrm{Km}^{2} \cdot[9]$

Esta área de abrangência possui uma população total de 2.824.613 habitantes, segundo o Censo Demográfico de 2011 (BRASIL, IBGE, 2011). Para atender essa região, o IFNMG agrega 10 (dez) Campi (Almenara, Araçuaí, Arinos, Diamantina, Januária, Montes Claros, 
Pirapora, Porteirinha, Salinas e Teófilo Otoni) e um Campus Avançado: Campus Janaúba.

Oficialmente o Campus Arinos, foi integrado ao IFNMG em 6 de janeiro de 2009 de acordo com a portaria do Ministério da Educação (Portaria n. 4, de 6 de janeiro de 2009). [9]. A figura 4 apresenta a distribuição dos Campus do Instituto Federal de Educação, Ciência e Tecnologia do Norte de Minas Gerais.

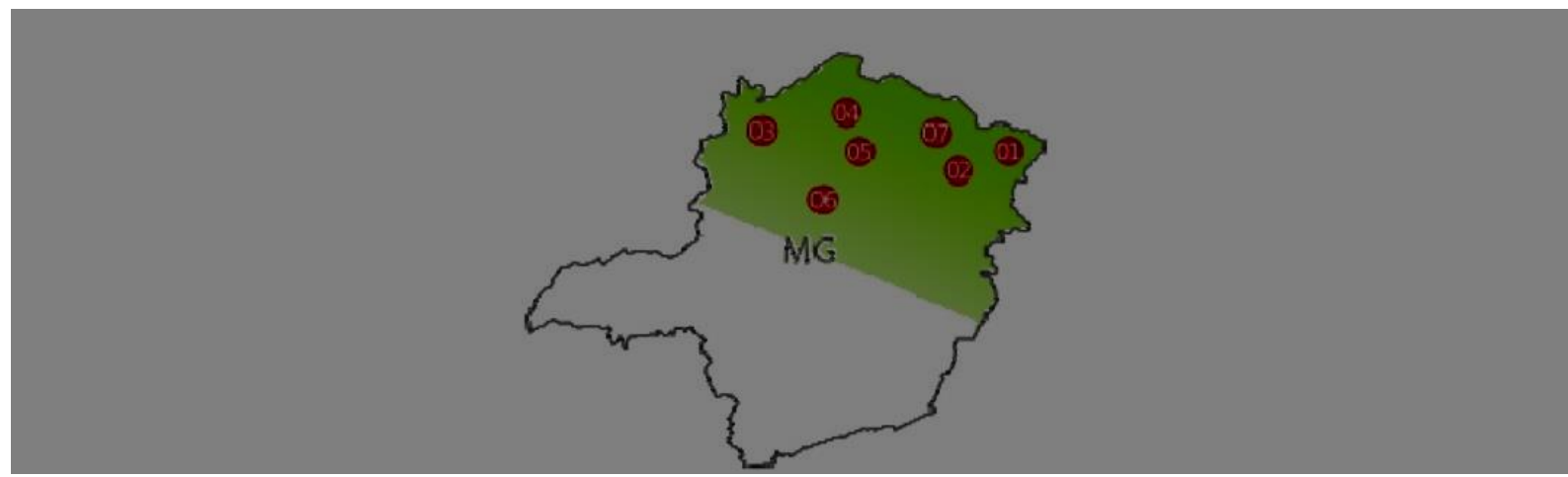

Figura 4: Distribuição dos Campus do IFNMG.

$$
\text { Fonte - [9] }
$$

Iniciada em 2006, com a implementação do Plano de Desenvolvimento da Educação (PDE), a ampliação e expansão da oferta de educação profisssional, via Governo Federal, prioriza as regiões mais carentes do país para a implantação de escolas profissionalizantes, no intuito de promover atividades econômicas autossustentáveis, renda e, consequentemente, desenvolvimento social. Neste contexto de mudanças, a educação profissional e tecnológica passa por profunda reestruturação, sobretudo, com a criação dos Institutos Federais de Educação, Ciência e Tecnologia. Assim como em outros estados e regiões do país, visando ao crescimento e à estruturação socioeconômica, foi idealizado o Instituto Federal de Educação, Ciência e Tecnologia do Norte de Minas Gerais resultado da parceria entre o Centro Federal de Educação Tecnológica de Januária e a Escola Agrotécnica Federal de Salinas, ambos com larga experiência no ensino agrícola e profissionalizante. [9]

Missão do IFNMG, produzir, disseminar e aplicar o conhecimento tecnológico e acadêmico, para a formação cidadã, por meio do ensino, da pesquisa e da extensão, contribuindo para o progresso sócio econômico local, regional e nacional, na perspectiva do desenvolvimento sustentável e da integração com as demandas da sociedade e do setor produtivo. [ 9] 
Visão, manter e ampliar o reconhecimento como instituição de excelência em educação profissional, científica e tecnológica na sua área de abrangência. [ 9 ]

\subsubsection{Histórico do IFNMG, Campus Arinos (MG)}

O Instituto Federal do Norte de Minas Gerais (IFNMG), Campus Arinos, iniciou oficialmente suas atividades no ano de 2009. O IFNMG é uma instituição de educação que oferta cursos de nível técnico, nas modalidades Integradas ao Ensino Médio, Concomitante e Subsequente e Superior. Sendo assim, o Campus Arinos visa o trabalho em benefício da consolidação e do fortalecimento dos arranjos produtivos sociais e culturais locais, identificados com base no mapeamento das potencialidades do desenvolvimento socioeconômico e cultural da região. A figura 5 representa a localização da cidade de Arinos dentro do estado Minas Gerais.

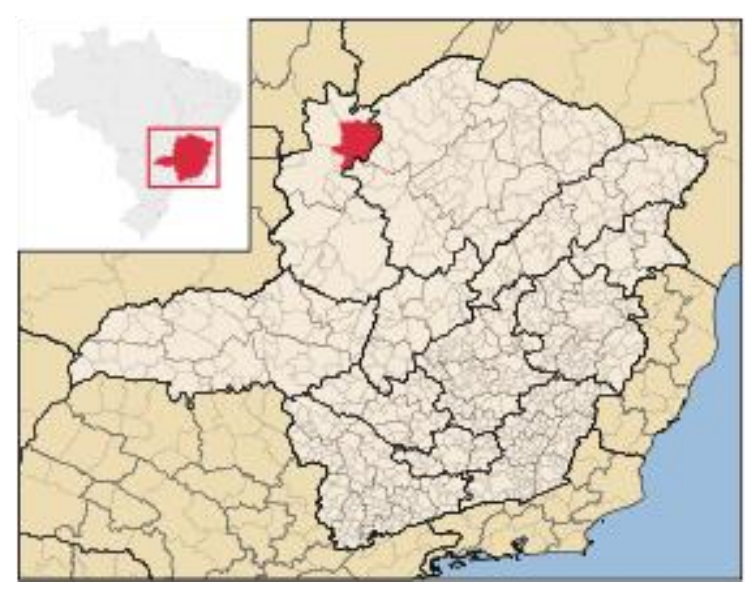

Figura 5: Mapa de Arinos

$$
\text { Fonte - [9] }
$$

Com isso, o IFNMG - campus Arinos, por meio da oferta da educação profissional técnica de nível médio e Superior, forma e qualifica cidadãos com vistas na atuação profissional nos diversos setores da economia local.

A cidade de Arinos, sede do campus do IFNMG, e as cidades circunvizinhas possuem grandes empresas agroindustriais e comerciais que podem se beneficiar do uso das Tecnologias da Informação, além de ser uma promessa para um grande polo de desenvolvimento de sistemas.

Assim, o Instituto Federal de Educação, Ciência e Tecnologia do Norte de Minas Gerais 
- Campus Arinos, encontra-se localizado na Rodovia MG 202, Km 407, a 4 Km da cidade de Arinos; ocupa uma área de 59 ha, onde estão sendo desenvolvidos projetos nas áreas agrárias, com perspectiva de desenvolvimento de projetos na área da Tecnologia da Informação mediante a implantação do Centro de Desenvolvimento Tecnológico e Inovação (CDTI). [ 9 ]

O Campus Arinos abrange uma área de 27.653,10 $\mathrm{Km}^{2}$, a microrregião de Unaí no Noroeste de Minas Gerais (Figura ), com uma "população de 142.122 habitantes" [10], sendo composta por 9 municípios: Buritis, Formoso, Arinos, Cabeceira Grande, Unaí, Uruana de Minas, Bonfinópolis de Minas, Natalândia e Dom Bosco. Atende ainda, de forma direta, cidades circunvizinhas com forte relação socioeconômica e cultural com Arinos: as cidades de Chapada Gaúcha, Riachinho e Urucuia. [ 8 ]

Referente à taxa de crescimento populacional, na região Noroeste de Minas a população aumentou de 305.285 habitantes para 334.509, num total de crescimento de 9,6\% .[10]

No entanto os pequenos municípios perdem a cada ano uma parcela significativa da população, em especial a juventude e a economicamente ativa, que migra especialmente para a capital federal ou ainda para as maiores cidades da região em busca de melhores condições de vida e oportunidades de formação acadêmica nas faculdades e Universidades de Unaí, Paracatu e Brasília-DF.

As atividades do Campus Arinos iniciaram-se no primeiro semestre do ano de 2009, tendo como Diretor Geral, o Professor Edmilson Tadeu Cassami. No primeiro semestre desse mesmo ano, foram ofertados pelo Campus os primeiros cursos técnicos, a saber: Informática e Agropecuária, sendo todos eles na modalidade concomitante. Passando no ano seguinte para a oferta dos cursos técnicos de Informática, Agropecuária e Administração na modalidade concomitante/subsequente e integrado ao ensino médio para os cursos de Informática e Agropecuária.

Fazendo parte da expansão da Rede Federal de Educação, Ciência e Tecnologia, o Campus Arinos ampliou sua oferta de cursos. Atualmente, o Campus oferece cursos Técnicos (Integrado, Subsequente e Concomitante), curso Superior em Bacharelado, curso Superior em Tecnologia e ainda conta com programas educacionais como a Rede e-Tec Brasil, Mulheres Mil e o Pronatec.

De acordo com a Secretária de Registros Escolares no primeiro semestre de 2014, o Campus Arinos encontrava-se com 1930 alunos matriculados. De acordo com o anexo C.

Diante desse contexto, é crescente a demanda por profissionais capacitados que possam 
atender a todos os setores da economia. Ciente de tal situação, o IFNMG buscou identificar, por meio de várias reuniões técnicas e Audiências Públicas com os diversos setores da sociedade civil organizada e população local, realizadas na Câmara Municipal, em Arinos, e com base nas características socioeconômicas e no perfil comercial da região, as áreas de atuação profissional nas quais tal demanda é mais iminente.

Dessa forma, foi verificada a necessidade de cursos superiores e cursos para a formação técnica de nível médio voltado para o atendimento aos empreendimentos da região. Assim, no seu plano de metas, o IFNMG - Campus Arinos contempla eixos tecnológicos como Informação e Comunicação. Dando continuidade ao processo de ampliação e em conformidade com o princípio da verticalização, o IFNMG - Campus Arinos apresenta o presente Projeto Pedagógico para o curso Técnico em Informática Integrado ao Ensino Médio, o qual foi construído tendo em vista o contexto local e regional no qual o Campus se insere e as condições de infraestrutura física e quadro de pessoal existente na Instituição. 


\section{MODELOS PEDAGÓGICOS DE APRENDIZADO}

Embora o assunto conduza a uma ampla discussão, pois impõe o conhecimento dos fundamentos da própria área de aprendizagem e da Psicologia, enquanto ciência, as considerações feitas neste texto sobre o assunto têm como finalidade contextualizar as teorias da aprendizagem de forma a se compreender as escolhas feitas na construção do modelo a ser adotado.

Um dos principais objetivos de um sistema de aprendizagem é proporcionar condições para que os alunos possam adquirir novos conhecimentos e, consequentemente, possam aplicálos na sua prática profissional. Estes objetivos podem ser atingidos de forma mais ou menos eficaz, dependendo em grande parte das estratégias pedagógicas utilizadas. A seguir os três principais tipos de modelos pedagógicos, conforme mostrados na Figura 3.1, são descritos. [11]

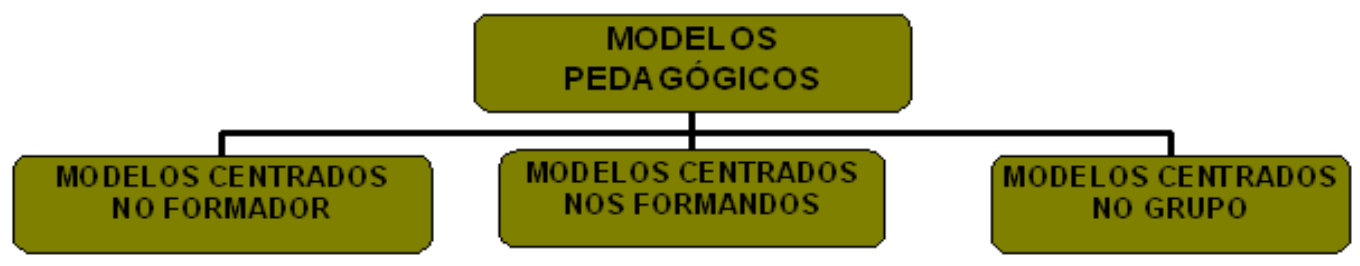

Figura 3.1 - Os três principais tipos de modelos pedagógicos.

Fonte $-[11]$

Os Modelos Centrados no Formador são modelos pedagógicos tradicionais, e se caracterizam pela mera transferência de informação do formador para o formando, recorrendo à utilização de métodos expositivos. O formando comporta-se de forma absolutamente passiva, enquanto que o formador possui todo o controlo sobre o processo de formação e sobre o próprio ritmo da aprendizagem. [11]

Nos Modelos Pedagógicos Centrados no Formando, toda a informação recebida é submetida a um processo de interpretação, conducente à construção de novas formas de conhecimento. O formando aprende ao seu próprio ritmo, interpretando os fatos com base na sua experiência pessoal. O formador atua como um facilitador e orientador do processo de 
aprendizagem, proporcionando meios para o desenvolvimento de novas competências nos formandos. [11]

O Modelo Centrado no Grupo, baseia-se na implementação de ambientes de trabalho colaborativo, nos quais o conhecimento é construído com base na interação entre todos os elementos do grupo de trabalho. Este modelo revela-se bastante adequado em contextos orientados para a resolução de situações com algum grau de complexidade, onde a criatividade dos formandos é demandada. O formador tem como função facilitar a troca de informação e de conhecimento entre os formandos, intervindo nos debates e providenciando para que todos os formandos interajam mutuamente. [11]

A metodologia de aprendizado proposta irá mesclar de forma eficaz e harmônica características provenientes dos três modelos pedagógicos, dando origem a um metodologia de aprendizado híbrida conhecida por Blended Learning.

\subsection{A EDUCAÇÃO TRADICIONAL}

A pedagogia atual indica que educar significa preparar o indivíduo para uma sociedade em constante transformação, aceitando desafios propostos pelo surgimento de novas tecnologias. Apesar disso, as escolas, ainda trabalham com a metodologia expositiva. Nessa, o sujeito não interage com o objeto de conhecimento.

"Nesse modelo de escola, o professor passa para o aluno, através da exposição verbal da matéria, de exercícios de memorização e fixação de conteúdo, de leituras em livros didáticos, os conhecimentos adquiridos ao longo dos anos pelas diferentes culturas." [12]. O aluno recebe tudo pronto, não é incentivado a problematizar e nem é solicitado a questionar ou fazer relação do que aprende com o que já conhece. Por isso, é frequentemente caraterizado como passivo.

A metodologia expositiva persiste até hoje, isso acontece devido a uma série de fatores como, por exemplo: [12]

"A família, que se sente segura, pois a escola de seus filhos pratica uma educação tradicional; o professor, que é qualificado na medida em que cumpre o que se espera dele: manter a disciplina e supervalorizar o conteúdo; os processos avaliativos que reforçam essa metodologia, quantificando o conhecimento transmitido e nem sempre aprendido pelo aluno. A falta de tempo para realizar trabalhos que envolvem efetivamente os alunos, é respaldada pelos 
extensos programas a cumprir. Economicamente também é mais viável, pois as salas de aula podem comportar um número elevado de alunos, todos assentados em fileiras bem organizadas nesse espaço físico.”

Nesse modelo tradicional de ensino, baseado em metodologias expositivas e na fixação e memorização, o conteúdo tem pouca aplicabilidade na realidade, na vivência do aluno. Essa metodologia tem sido pouco eficiente no processo de ensino-aprendizagem, pois o aluno tem dificuldades para refletir, pensar e criar soluções para situações práticas.

Os alunos acumulam saberes, são bem avaliados em suas provas periódicas, mas não conseguem transferir o que aprenderam para situações reais de suas vidas. O sistema de avaliação mede a quantidade de informação absorvida e enfatizada a memorização, a reprodução do conteúdo por meio de exercícios, privilegia a preparação para o vestibular desde o início da vida escolar.

O professor é a autoridade maior em relação aos seus alunos. Ele é a fonte de todas as informações. Por dominar um conhecimento, é quem pode transferi-lo; o que ele ensina sobrepõe a construção do conhecimento pelo aluno.

No quadro 3.1 apresenta as características do Ensino Tradicional, caracterizando a escola, o professor e o aluno.

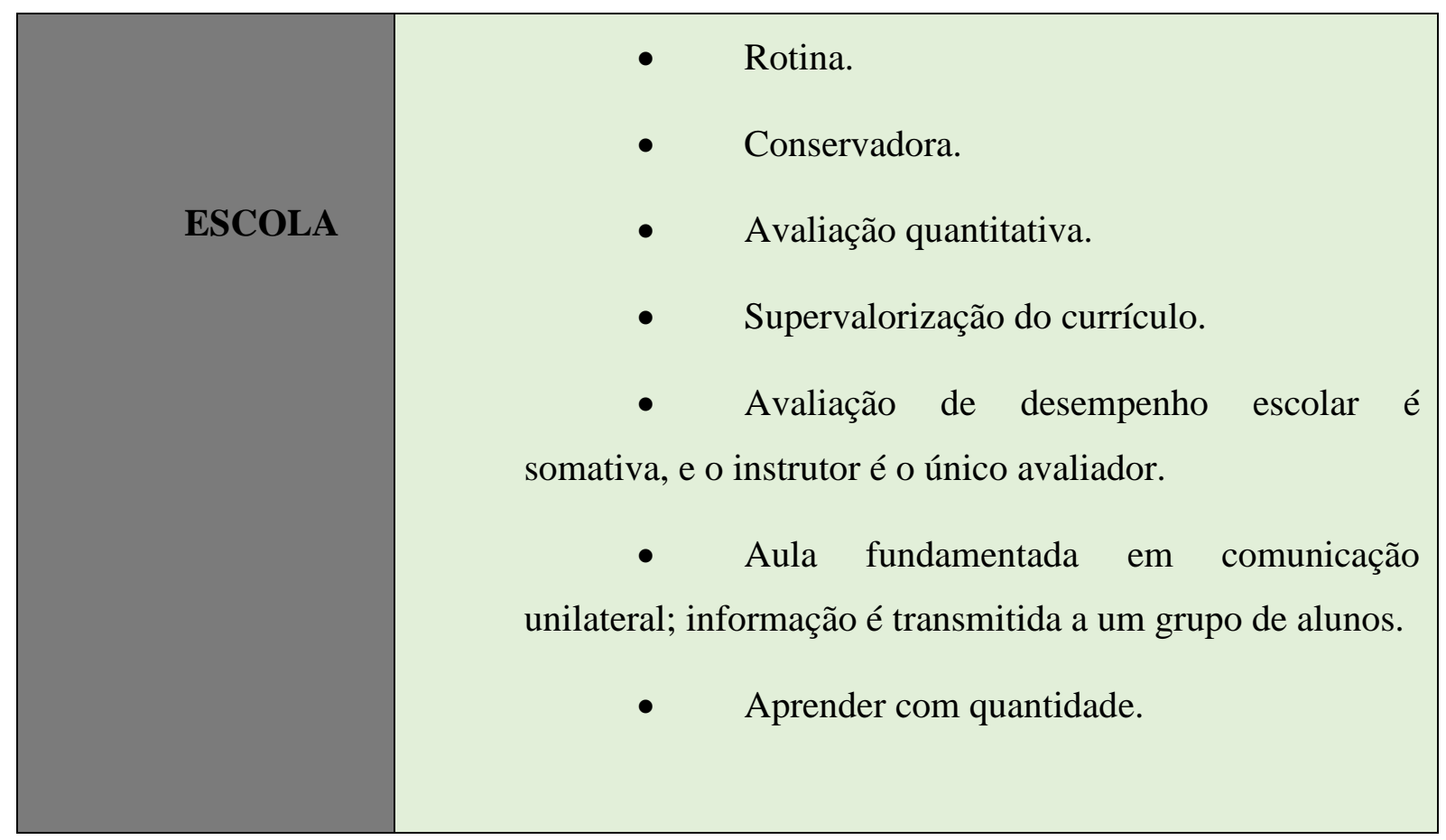


- Assume o papel de especialista ou autoridade formal.

DOCENTE

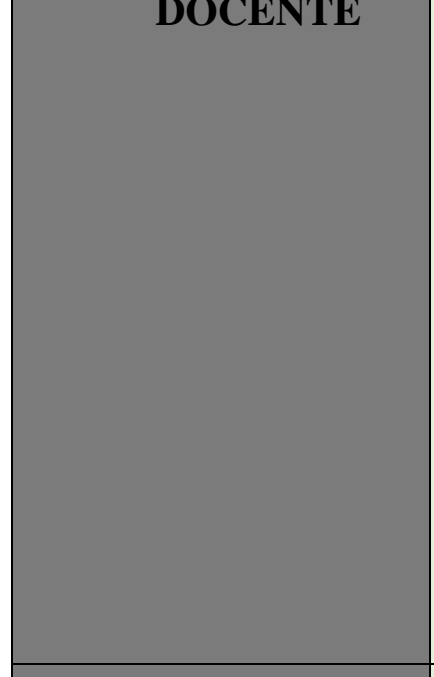

ALUNO

- Trabalham isoladamente.

- Transmitem informações aos alunos.

- Organizam os conteúdos na forma de palestras, com base no contexto da disciplina.

- Trabalham individualmente nas disciplinas.

- Não relaciona o conteúdo com a vivência dos alunos.

- São vistos como receptores passivos de informação.

- Trabalham isoladamente.

- Absorvem, transcrevem, memorizam e repetem informações para realizar tarefas de conteúdo específico, tais como questionários e exames.

- Aprendizagem é individualista e competitiva.

- Busca a "resposta correta" para obter sucesso em uma prova.

- $\quad$ Não interage com o objeto de conhecimento.

Quadro 3.1 - Metodologia do Ensino Tradicional

Fonte - [3]

Percebe-se que nessa metodologia de ensino o conhecimento é de forma fragmentada e 
que utiliza como metodologia de avaliação, somente métodos quantitativos para avaliar seus alunos e professores.

O aluno que aprende com essa metodologia não interage com o professor assim é perceptível a sua falta de envolvimento e motivação no processo ensino-aprendizagem. $\mathrm{O}$ aluno tem que ter autonomia para resolver situações rotineiras em sala de aula, participar de atividades em grupo de forma que gera interação entres os membros da equipe, portanto, é preciso valorizar o saber do aluno.

\subsection{APRENDIZAGEM COLABORATIVA}

$\mathrm{Na}$ aprendizagem colaborativa, o aluno é o responsável por sua própria aprendizagem e pela aprendizagem dos outros membros do grupo. Os alunos constroem conhecimento através da reflexão a partir da discussão em grupo. A troca ativa de informações instiga o interesse e o pensamento crítico, possibilitando aos alunos alcançarem melhores resultados do que quando estudam individualmente. [13]

Nessa aprendizagem o aluno é estimulado: a interação em equipe, ao pensamento crítico, resolução de problemas trocas de informações e experiências.

A aprendizagem colaborativa seria um grupo de duas ou mais pessoas trabalhando com objetivos comuns, auxiliando-se mutuamente na construção de conhecimento. Essa aprendizagem pode assumir múltiplas caracterizações, podendo haver dinâmicas e resultados de aprendizagem diferentes para cada contexto específico.

Esse conceito pode ser interpretado de várias maneiras: o número de sujeitos pode sofrer grande variação, podendo ser duas ou milhares de pessoas; aprender algo também é um conceito muito amplo, pois pode significar o acompanhamento de um curso ou ainda a participação em diversas atividades como, por exemplo, as de resolução de problemas; o aprender " em conjunto" pode ser interpretado de diversas maneiras, como situações de aprendizagem presenciais ou virtuais, síncronas ou assíncronas, esforço totalmente em conjunto ou com divisão de tarefas. [14]

Na formação de grupos de estudos e também de trabalhos colaborativos, o que se busca é uma parceria entre os indivíduos participantes que vá além da simples soma de mãos para a execução de um trabalho. [14] 
No quadro 3.2 é apresentada a diferença entre o ensino tradicional e a aprendizagem colaborativa.

\begin{tabular}{|c|c|}
\hline Ensino Tradicional & Aprendizagem Colaborativa \\
\hline $\begin{array}{c}\text { - } \text { Estudo isolado. } \\
\text { - } \text { Professor - autoridade. } \\
\text { - } \text { Aluno - recipiente a ser } \\
\text { preenchido com informações do } \\
\text { professor. } \\
\text { - Aprendizagem reativa, passiva. } \\
\text { - } \text { Semorização de informações. } \\
\text { - Centrada no Professor. } \\
\text { - Ênfase no produto. } \\
\text { - Sala de aula }\end{array}$ & $\begin{array}{l}\text { Estudo em grupo. } \\
\text { - } \text { Professor - orientador. } \\
\text { - Aluno - agente que transforma a } \\
\text { informação em conhecimento } \\
\text { através da interação social } \\
\text { - Aprendizagem ativa, } \\
\text { investigativa. } \\
\text { - Discussão e construção do } \\
\text { conhecimento. } \\
\text { Formação de grupos em função } \\
\text { da competência } \\
\text { - Centrada no aluno. } \\
\text { - Ênfase no processo. } \\
\text { Ambiente de aprendizagem. }\end{array}$ \\
\hline
\end{tabular}

Quadro 3.2 - Comparativo do ensino tradicional e abordagem colaborativa Fonte $-[13]$

Na aprendizagem colaborativa, valoriza-se a participação do aluno e suas competências em resolver problemas. Se o aprendiz demonstrou ter as competências necessárias a partir de suas participações no curso, então passa de fase semelhantemente ao que ocorre nos videogames. [13].

A figura 3.2, mostra os quatros pilares da Aprendizagem colaborativa: aprender a conhecer, aprender a fazer, aprender a viver juntos e aprender a ser [16] 


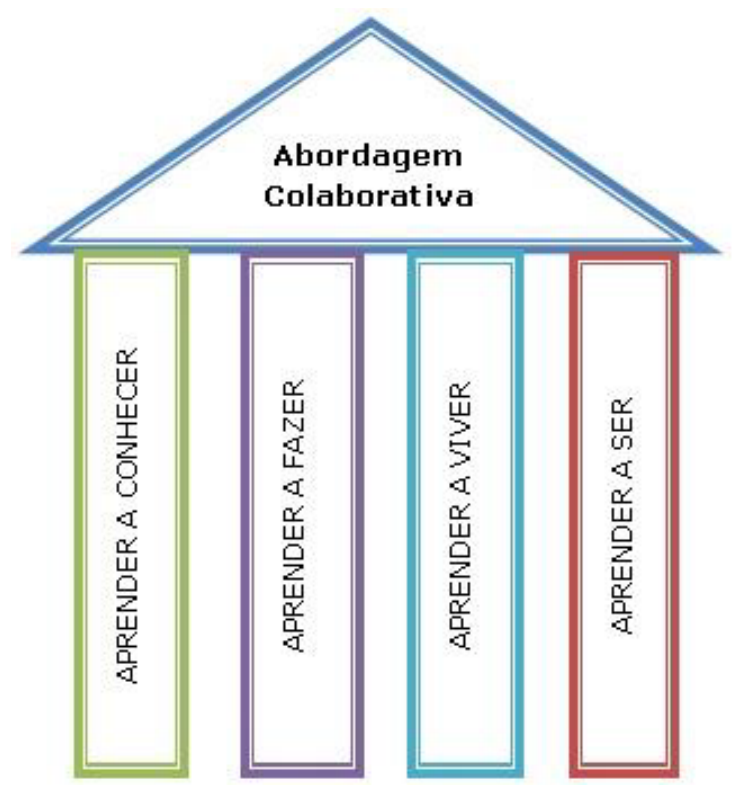

Figura 3.2 - Quatro pilares da Aprendizagem colaborativa.

$$
\text { Fonte }-[3]
$$

No pilar aprender a conhecer o fundamental é incentivar o prazer em descobrir, em investigar, em construir e reconstruir o conhecimento, despertando a curiosidade intelectual.

No pilar aprender a fazer, torna-se necessário a evolução da aprendizagem através de novas formas de ensino, não podendo mais ser consideradas como simples transmissão de práticas mais ou menos rotineiras.

O terceiro pilar, aprender a viver juntos, significa ter prazer no esforço comum, participar de projeto de cooperação.

No quarto pilar, aprender a ser, tem-se o desenvolvimento integral da pessoa: sensibilidade, sentido ético e estético, inteligência, responsabilidade pessoal, pensamento crítico e criatividade.

\subsubsection{Embasamento Teórico da Aprendizagem Colaborativa}

As principais bases teóricas e tendências pedagógicas que embasam a aprendizagem colaborativa e que serão utilizadas como referencias na elaboração do modelo a ser utilizado neste trabalho são:

- Teoria da Epistemologia Genética - Jean Piaget

- Teoria Sociocultural - Lev Vygotsky; 
- Teoria do Construcionismo - Seymour Papert

\subsubsection{Epistemologia Genética de Piaget}

O termo epistemologia Genética, é o estudo crítico dos resultados das diversas ciências e das hipóteses, destinado a determinar a sua origem lógica e seu valor. Por isso Piaget definiu sua teoria de Epistemologia Genética, pois se centrava na gênese, na origem.

De acordo com essa percepção, o conhecimento não é um objeto inarredável, mas produzido pelo indivíduo por meio da sua experiência com o objeto do conhecimento. A teoria Piaget mostra que a aprendizagem ocorre quando a relação entre o indivíduo e o seu meio de relações está em plena interação.

Alguns pontos resume a teoria de Piaget. [17] São eles:

- O indivíduo precisa expressar o que sente livremente, pois através do falar, suas ideias são consolidadas;

- O indivíduo precisa participar do processo de transformação. À medida que ele tenta transformar o meio para satisfazer uma necessidade (assimilação), ele se depara com resistências que o obrigam a um esforço de adaptação e, portanto, ocorre a aprendizagem;

- O indivíduo não precisa participar do receber respostas prontas. Através dos seus erros e acertos, do expressar o que pensa, tomando consciência do meio em que vive, ele desenvolve um ciclo de aprender a aprender;

- O indivíduo aprende mais quando não corre risco de ser discriminado ou de perder algo. Dinâmicas de grupo, jogos de empresa, simulação e realidade virtual são algumas ferramentas que auxiliam o indivíduo a aprender brincando;

- O indivíduo, normalmente, procura novas situações. É curioso por natureza e busca sempre o novo;

- O indivíduo precisa se sentir seguro e aceito para desenvolver atitudes e conviver com situações diferentes, sabendo lidar com as mudanças.

Segundo Piaget, esse processo só ocorre quando a capacidade do indivíduo é desenvolvida para conhecer algo ou descobrir algo. Isto ocorre através da interação entre o 
indivíduo e o objeto gerador de conhecimento. Essa relação é chamada de Construtivismo. [18]

A abordagem construtivista destaca atividades desafiadoras que colocam discentes e docentes na comunidade de aprendizagem. O objetivo dessa metodologia é a construção de uma aprendizagem que se assemelham com a prática colaborativa do mundo contemporâneo.

Através dessa abordagem, espera-se, que, os alunos desenvolvam habilidades técnicas e não técnicas para monitorar e dirigir sua própria aprendizagem. Cada aluno envolvido nos trabalhos em equipe consegue ver o caso ou problema de uma perspectiva diferente e estão habilitados a ajustar e gerar soluções por meio de uma aprendizagem compartilhada.

A Figura 3.3 mostra um mapa conceitual dos trabalhos Piaget que deram origem ao construtivismo.

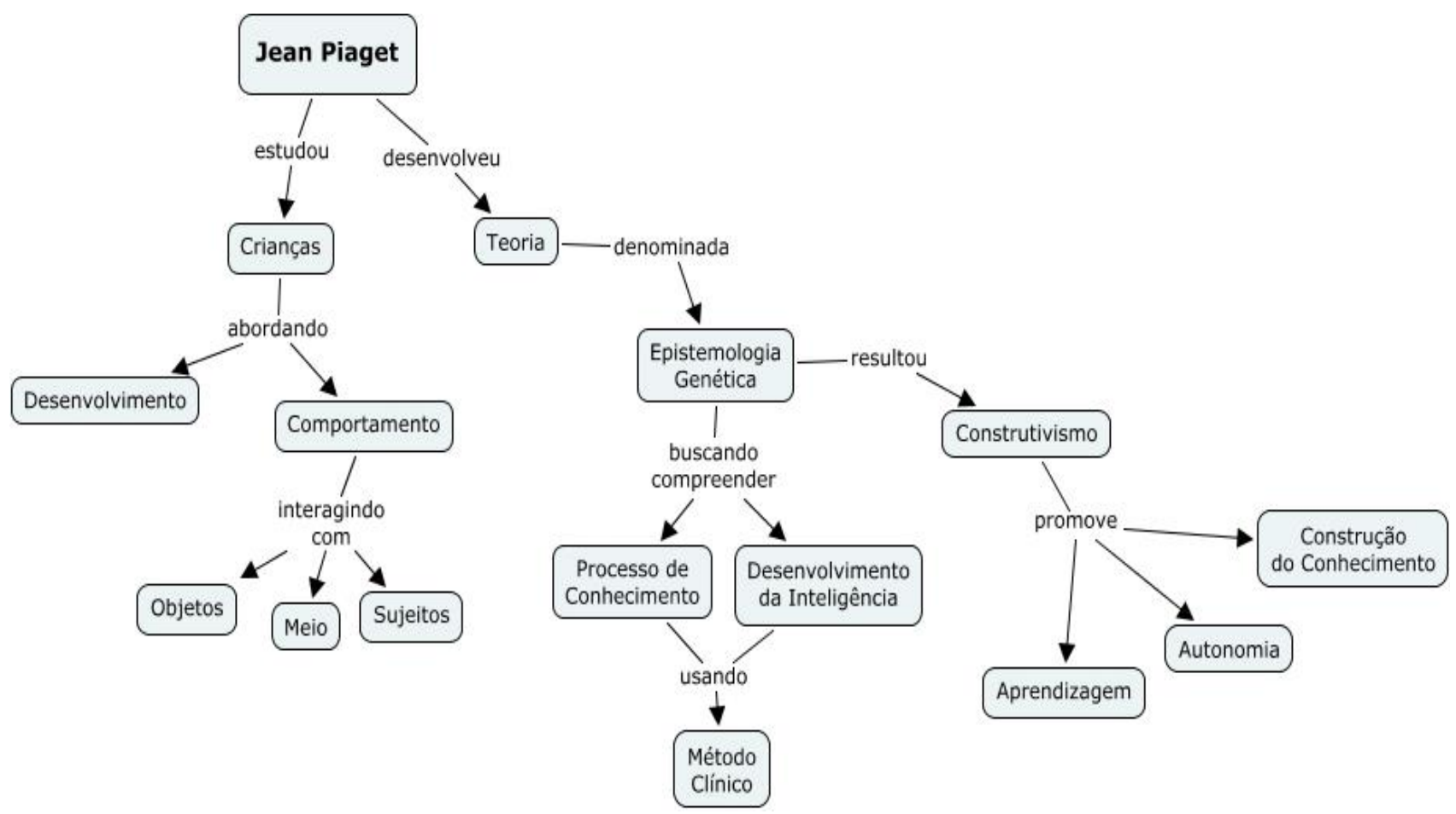

Figura 3.3 -Mapa Conceitual do trabalho de Piaget

Fonte $-[18]$

\subsubsection{Teoria Sociocultural de Vygostsky}

A teoria Sociocultural se caracteriza pela relação entre a interação social e o desenvolvimento cognitivo do indivíduo. "ele [ Vygotsky] considera que o indivíduo é um ser social e que constrói sua individualidade a partir das interações que se estabelecem entre os indivíduos, mediadas pela cultura”. [19] 
Essa teoria enfatiza o papel da linguagem no desenvolvimento do indivíduo e o processo histórico-social. Seu objetivo principal é a aquisição de conhecimentos pela interação do aluno com o meio. Para o teórico, o aluno é interativo, pois adquire conhecimentos a partir de relação intra e interpessoais e de troca com o meio, a partir de um processo chamado mediação.

As características individuais e até mesmo suas atitudes individuais estão impregnadas de trocas com o coletivo, ou seja, mesmo o que tomamos por mais individual de um ser humano foi construído a partir de sua relação com o indivíduo. [20]

Zona de Desenvolvimento Proximal (ZDP), é a distância entre o nível de desenvolvimento real, ou seja, determinado pela capacidade de resolver problemas independentemente, e o nível de desenvolvimento proximal, demarcado pela capacidade de solucionar problemas com ajuda de um parceiro mais experiente. São as aprendizagens que ocorrem na ZDP que fazem com que a criança se desenvolva ainda mais. A Figura 3.4 sintetiza a metodologia de aprendizagem de Vigotski. [21]

\section{Teoria Sócio-Cultural de Vygotsky}

- Inteligência humana provém da sociedade ou cultura;

- Desenvolvimento cognitivo

- requer interação social

$\square$ limitado a um determinado potencial

\section{Zona Proximal de Desenvolvimento - ZPD}

- Trabalho em grupo $\square$ permitir o confronto e a integração de diferentes pontos de vista

facilitar a coordenação progressiva dos esquemas cognitivos ativar a reestruturação dos esquemas cognitivos

Figura 3.4 - Principais pontos da Teoria Sociocultural de Vygostsky

$$
\text { Fonte - [20] }
$$

Com base nessa teoria, o processo de aprendizagem deve ser olhado por uma ótica prospectiva, ou seja, não se deve focalizar o que o aluno aprendeu, mas sim o que ela está aprendendo. Nas práticas pedagógicas, sempre é necessário refletir como tal ou qual aprendizado poderá ser útil àquele aluno, não somente no momento em que é ministrado, mas para além dele. É um processo de transformação constante na trajetória dos discentes. As implicações da relação ensino e aprendizagem estão no fato de que o ensino deve se concentrar no que o aluno está aprendendo, e não no que já aprendeu. 
A figura 3.5 mostra o mapa conceitual da Teoria Sociocultural de Vigotski.

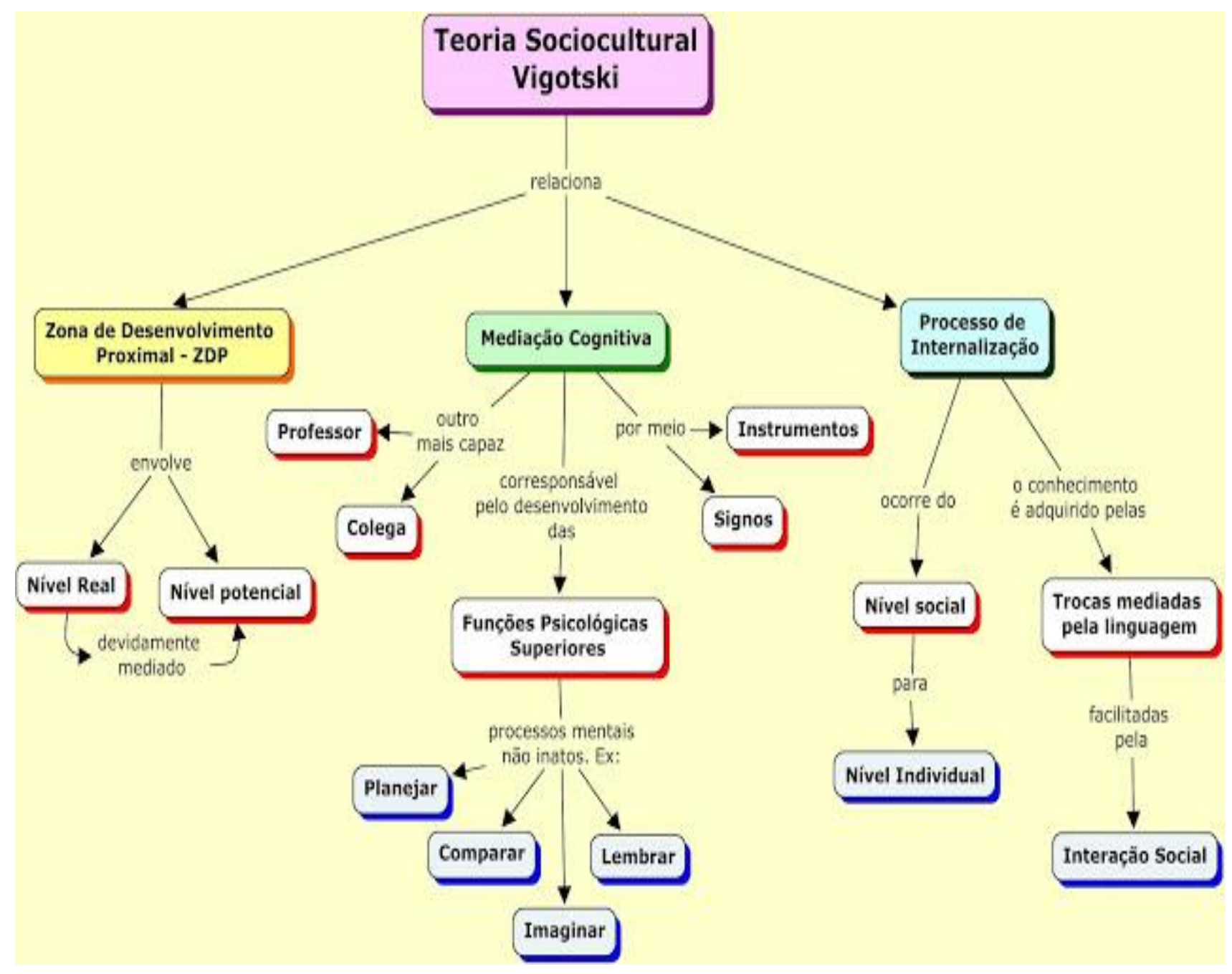

Figura 3.5 Mapa Conceitual da Teoria Sociocultural de Vigotski

$$
\text { Fonte }-[20]
$$

\subsubsection{Teoria do Construcionismo - Seymour Papert}

Para Seymour Papert, matemático, criador da proposta teórica conhecida como, construcionismo, seguidor do construtivismo de Jean Piageat, o aluno constrói seu próprio conhecimento, usando para isto ferramentas, como por exemplo: o computador. [22]

Para o Construcionismo, a aprendizagem acontece quando os aprendizes se ocupam na construção de qualquer coisa cheia de significado para si próprios, quer essa coisa seja um castelo de areia, uma máquina, um poema, uma história, uma canção, um programa de 
computador. Desse modo, o construcionismo envolve dois tipos de construção: construção das coisas (objetos, artefatos) que o aprendiz efetua a partir de materiais (cognitivos) recolhidos do mundo (exterior) que o rodeia, e construção (interior) do conhecimento que está relacionado com aquelas coisas. [23]

O construcionismo de Papert enfatiza o contato direto do aluno com o concreto. Manipular, interagir, errar, superar os erros através da interação com os objetos em uso, com o colega ou através da mediação feita pelo professor, [22]

O professor na proposta construcionista, tem o papel de mediador, facilitador, provocador de situações, e de ambientes de aprendizagem, onde o aluno possa construir seu conhecimento através de ações sobre coisas concretas.

Papert salienta que só aprendemos algo novo se realmente nos for significativo, desta forma, o interesse maior deve partir do aluno, haja vista, que o mesmo é o sujeito de sua aprendizagem e que esta dependerá da sua disposição em aprender e buscar. O aluno passa a ser o maior responsável pelo seu aprendizado, assimilando e atribuindo significados aos novos conhecimentos, porém é o professor o responsável, é quem vai orientá-lo na construção dos novos conteúdos, [22]. A Figura 3.6 sintetiza a filosofia construcionista

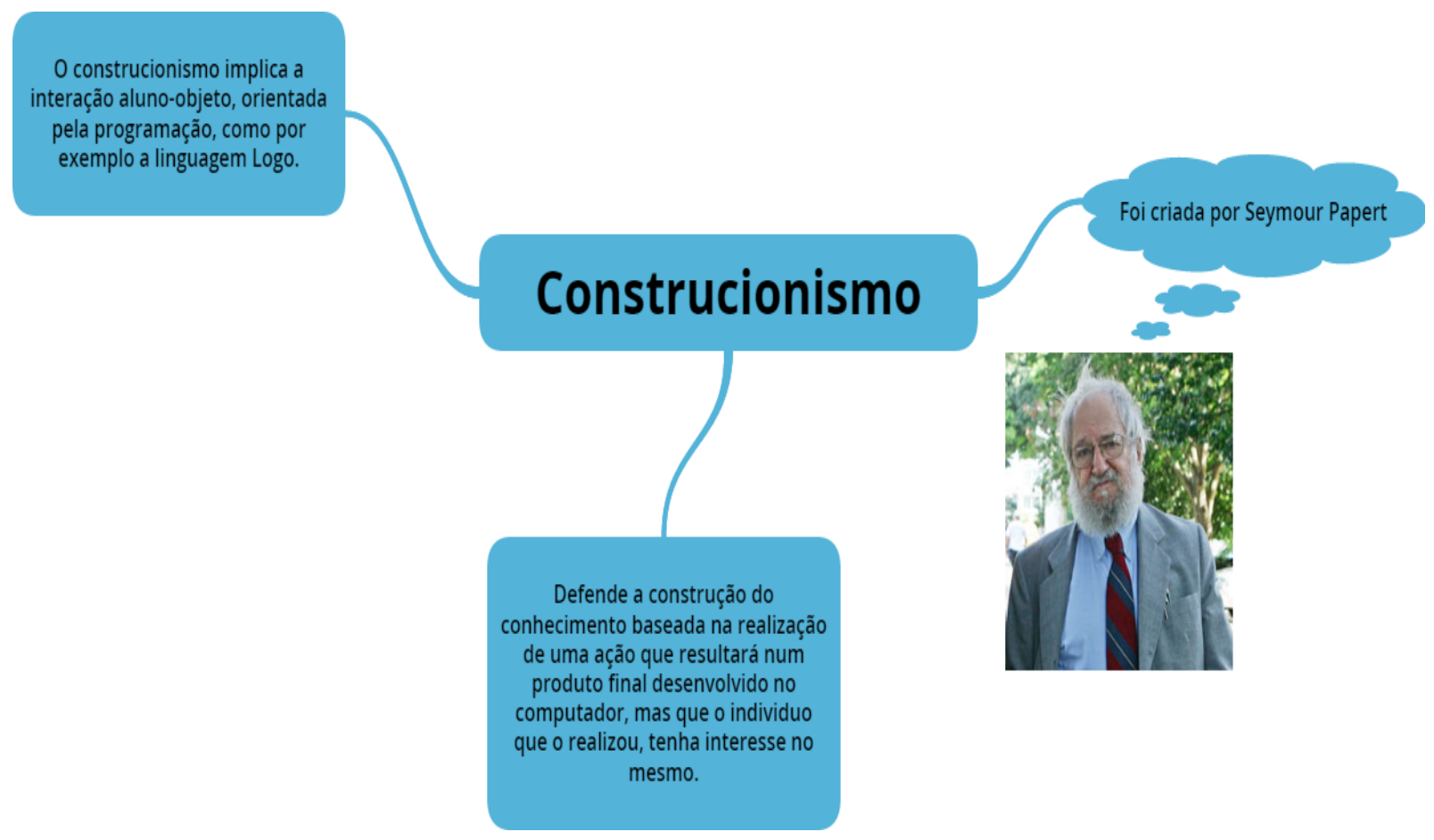

Figura 3.6 - A filosofia Construcionista

Fonte - [22] 


\subsection{APRENDIZAGEM HÍBRIDA}

Aprendizagem Híbrida ou Blended Learning é a combinação da educação tradicional com abordagem colaborativa, levando em consideração os aspectos fundamentais que ajudam a estruturar, de forma consciente, o processo educacional de modo a oportunizar mudanças de pensamentos, ações e condutas.

Um dos instrumentos mais eficazes para estruturar uma metodologia de aprendizagem diretamente relacionada ao conteúdo a ser assimilado, as atividades a serem desenvolvidas, aos recursos disponíveis, e aos instrumentos de avaliação é a taxonomia proposta por Bloom et al. (1956), que tem como objetivo ajudar no planejamento, organização e controle dos objetivos de aprendizagem. [24]

$\mathrm{Na}$ realidade a "Taxonomia de Bloom", consiste em um instrumento de avaliação e utilização de estratégias diferenciadas para facilitar, avaliar e estimular o desempenho dos alunos em diferentes níveis de aquisição de conhecimento. Seus objetivos educacionais são divididos em três domínios: cognitivo, afetivo e psicomotor, conforme ilustrado na Figura 3.7

- Cognitivo

- Vinculado com escalas que văo do conhecimento à sintese e avaliaçăo.

- Afetivo

- Vinculado afetos, valores, sen timentos, crenças.

- Psicomotor

- Vinculado às habilidades do corpo.

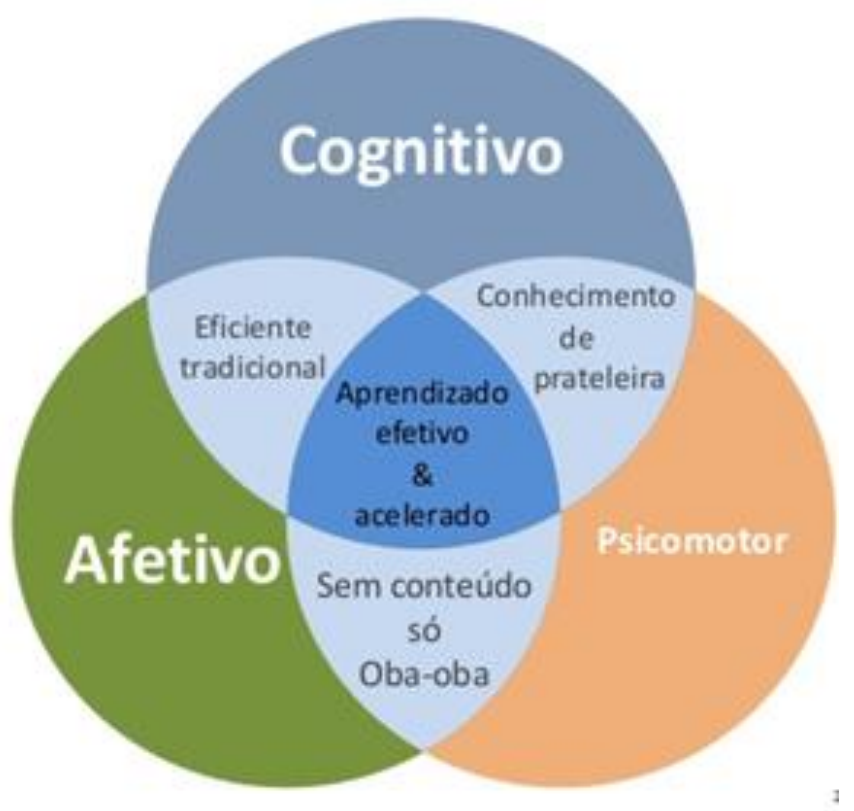

Figura 3.7 - Domínios básicos de aquisição do conhecimento utilizados por Bloom Fonte - [24] 
O modelo de Bloom sugere que os pensamentos e as habilidades humanas podem ser organizados em etapas de forma hierárquica para solucionar problemas, dando origem ao domínio cognitivo. Este domínio refere-se às características que faz com que o indivíduo recorde algo que foi aprendido, compreendendo seis classes de habilidades cognitivas: Conhecimento, Compreensão, Aplicação, Analise, Síntese e Decisão. Conforme ilustrado na Figura 3.8

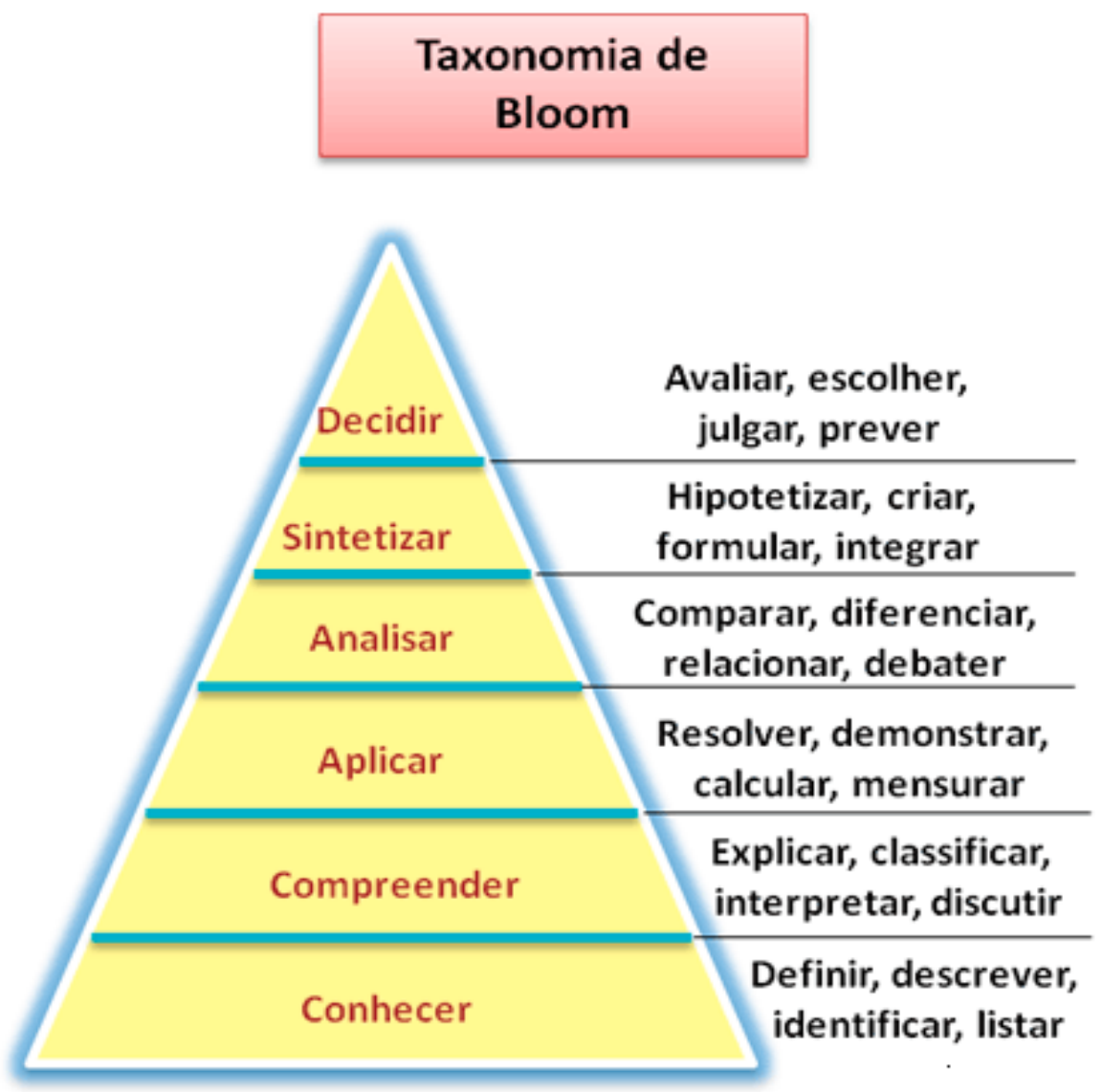

Figura 3.8 - Taxonomia de Bloom

Fonte $-[24]$

\subsubsection{Concepção do Modelo de Aprendizagem Híbrida}

O modelo de aprendizagem colaborativa desenvolvido neste trabalho é um instrumento pedagógico embasado no Taxinomia de Bloom que coloca o estudante como elemento ativo do processo de ensino-aprendizagem. Nesse modelo a combinação de atividades presenciais e não 
presenciais deve contribuir para um maior interesse dos estudantes em relação ao conteúdo a ser ministrado, permitindo assim, a dinamização da relação docente/estudante e gerando uma melhoria na qualidade de ensino.

A aprendizagem híbrida, também conhecida como "Blended Learning" é muitas vezes associada a uma combinação simples de sala de aula tradicional e de atividades e-learning. No entanto, o termo evoluiu para abarcar um conjunto muito mais rico de estratégias de aprendizagem. O elemento crucial na aprendizagem híbrida é o equilíbrio adequado entre o ensino presencial e uso da tecnologia. Nem o computador nem o World Wide Web podem substituir os instrutores, porém, ambos são suportes para os planos de ensino desenvolvidos, oferecendo uma infinidade de benefícios para o desenvolvimento de aprendizagem independente. As tecnologias da informação e comunicação, TICs, quando utilizadas adequadamente, tornam-se uma fonte de motivação para os alunos. [25]

Tradicionalmente os componentes de blended learning são classificados em síncronos e assíncronos. As atividades síncronas referem-se ao fato de que, as ações de ensino e aprendizagem acontecem ao mesmo tempo, isto é, em tempo real. Todas as atividades presenciais, como a sala de aula tradicional, são consideradas síncronas face a face, enquanto as atividades que simulam a situação de uma sala de aula a distância, como a videoconferência, são consideradas síncronas virtuais.

As atividades assíncronas são aqueles em que as interações não são ao vivo ou em tempo real. Elas são geralmente classificadas em duas categorias: colaboração virtual assíncrona e aprendizagem auto-didático. Colaboração virtual assíncrona utiliza recursos on-line de aprendizagem para facilitar o compartilhamento de informações entre as pessoas fora das restrições de tempo e de lugar. Os recursos de aprendizagem on-line utilizados para apoiar a aprendizagem assíncrona incluem e-mails, blogs, listas de endereços eletrônicos e fóruns de discussão on-line. A maioria destas ferramentas de aprendizagem pode ser implementada através de um ambiente virtual de aprendizagem, como o Moodle.

O aprendizado auto-didático está relacionado a experiências de aprendizagem em que o aluno adquire os conhecimentos necessários individualmente, em seu próprio ritmo e no seu próprio tempo, por meio de tutoriais on-line, software de simulações e de CD-ROM de treinamento.

Não existe uma fórmula estabelecida para selecionar a melhor combinação de recursos para atingir um objetivo estratégico [26]. Na realidade, uma vez que o perfil do aluno é 
conhecido e os objetivos do curso estão claramente definidos, o desafio é alinhar o conteúdo programático com o mix mais adequado, a fim de proporcionar um eficiente e eficaz ambiente de aprendizagem. A Figura 3.9 fornece uma visão geral de várias ferramentas do blended learning que podem ser utilizadas.

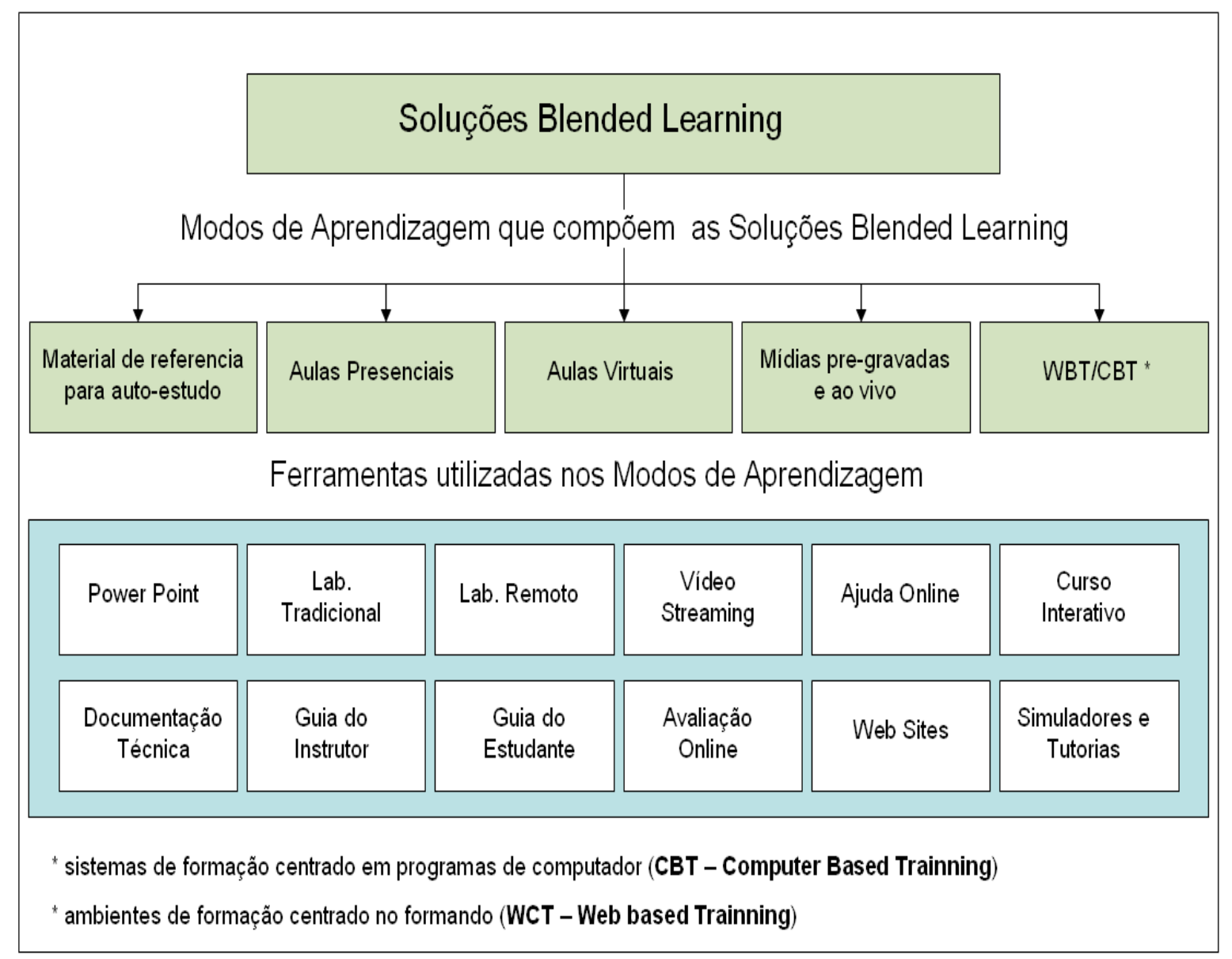

Figura 3.9 - Mapa dos Componentes do Blended Learning.

Fonte - [25]

O quadro 3.3 sintetiza as diferentes atividades que podem ser desenvolvidas nos modos síncrono, síncrono virtual e assíncrono. 


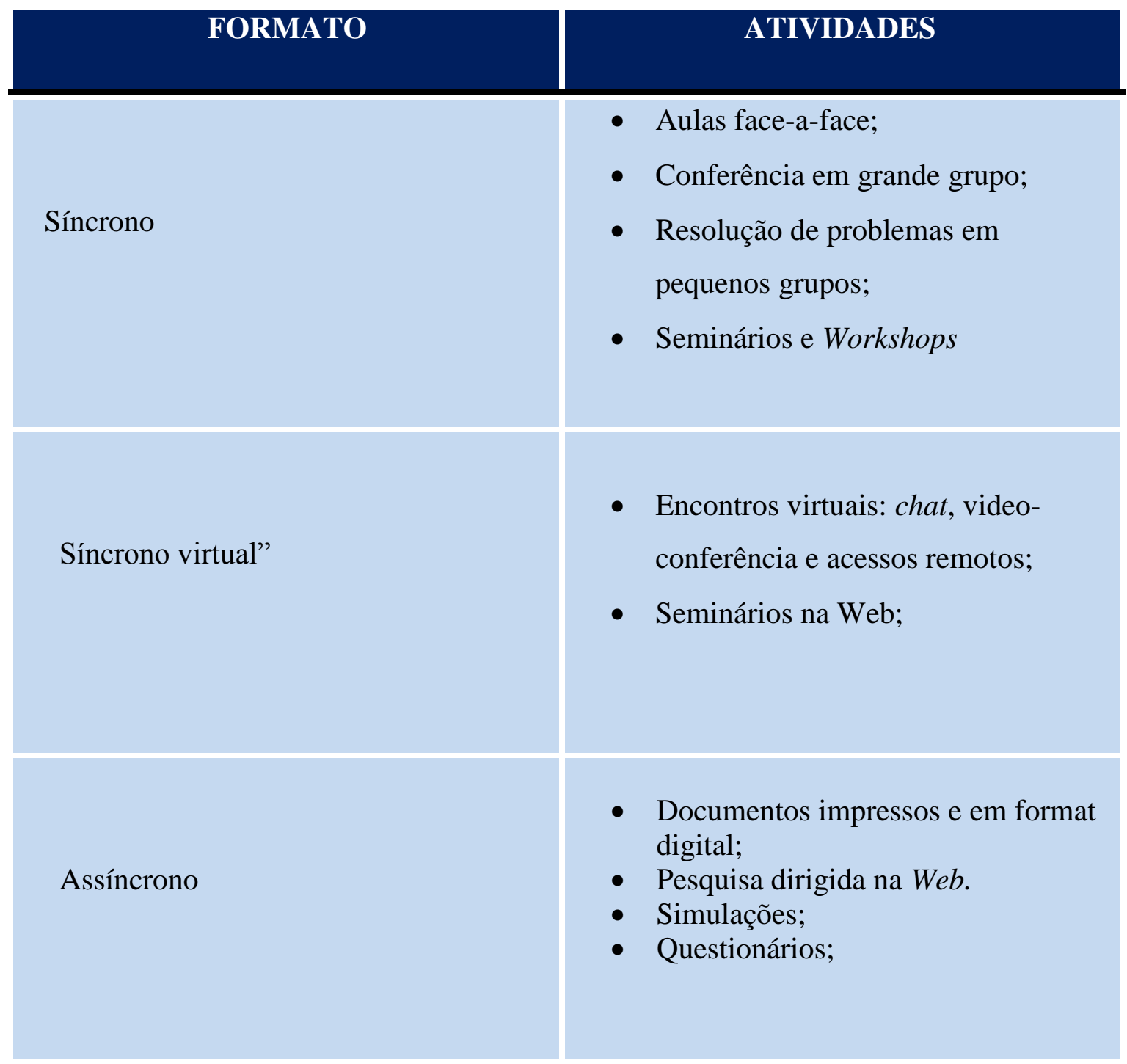

Quadro 3.3 - Atividades dos modos síncrono, síncrono virtual e assíncrono.

Conforme observado por [5] a pergunta mais frequente relacionada à concepção da metodologia Blended Learning é como escolher o que é mais adequado para ser ensinado online, e o que é mais apropriado para ser ministrado de forma presencial. A maneira mais eficaz de responder essa pergunta é de posse do plano aprendizagem verificar quais os tópicos deveriam ou poderiam ser melhor desenvolvidos em online, off-line ou por ambos. Por meio da Fig.15 adaptada de, De Deus et al, (2011) é possível ilustrar o procedimento a ser efetuado na 
escolha do modo de aprendizagem:(1) off-line (face-to-face) (2) off-line (trabalho individual) e (3) online.

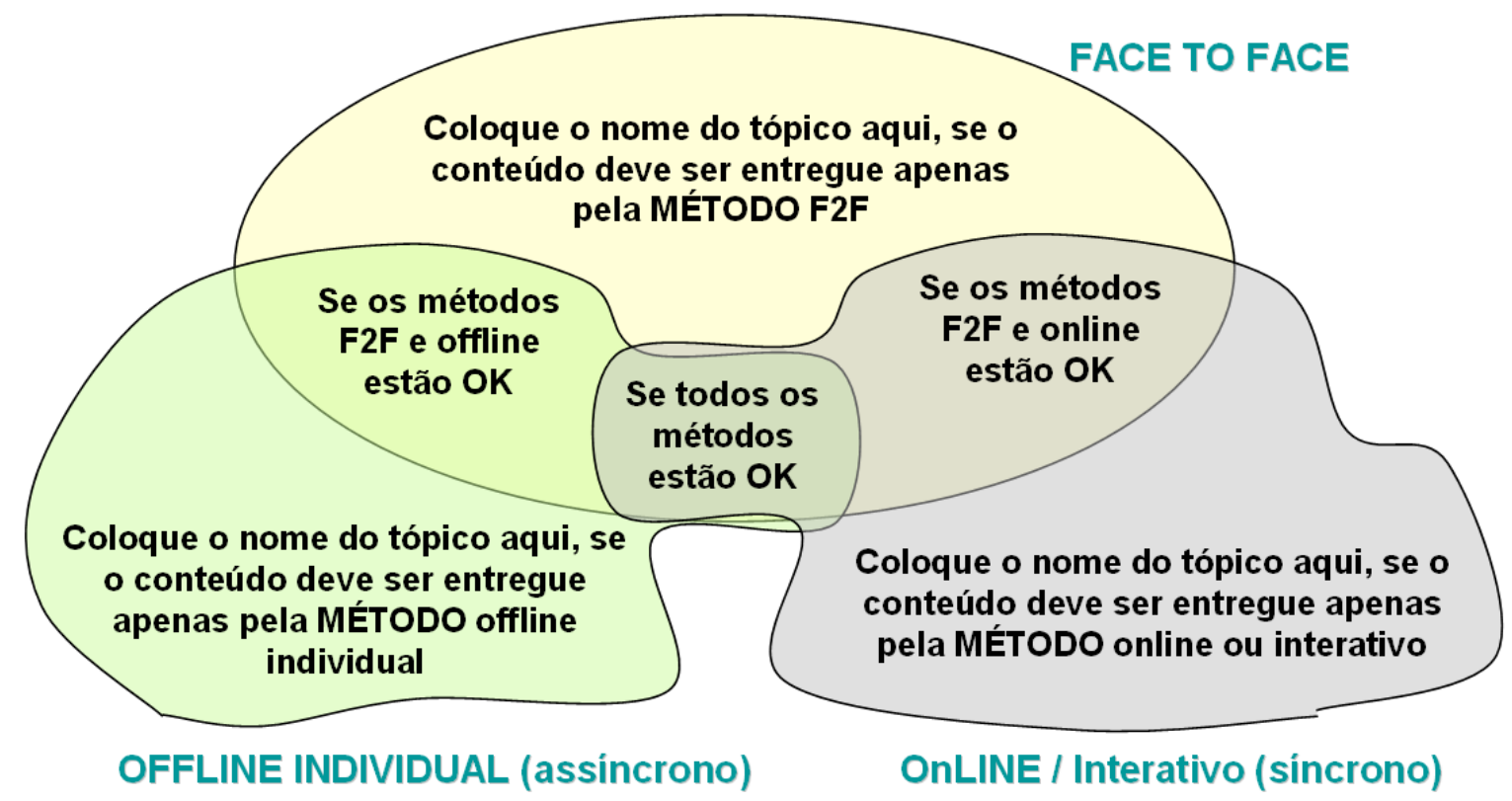

Figura 3.10 - Procedimento para a escolha do modo de aprendizagem a ser utilizado.

Fonte $-[25]$

A partir do exposto, pretende-se trabalhar uma metodologia de ensino onde várias técnicas de aprendizagem são integradas, visando um melhor aproveitamento do aluno na disciplina de Programação. Dentro dessa metodologia a ênfase foi dada na aprendizagem Híbrida com aplicação da Plataforma Arduino. 


\section{INCLUSÃO DA FERRAMENTA ARDUÍNO COMO ESTRATÉGIA PEDAGÓGICA}

\subsection{RADIOGRAFIA DO ENSINO}

Várias disciplinas presentes nos cursos técnicos da área de TI - Tecnologia da Informação (Computação, Informática e áreas afins) apresentam a programação de computadores como foco central, assunto que é tratado durante todo o curso, com diferentes abordagens e aplicações. O objetivo é tornar o indivíduo apto a utilizar a lógica de programação como ferramenta para a resolução de diversos problemas computacionais.

Porém, é de fácil constatação as dificuldades encontradas pelos alunos de assimilarem os aspectos básicos de algoritmos e lógica de programação ensinados, sendo comum a existência de enormes taxas de insucesso nas disciplinas de programação.

Visando melhorar o desempenho dos alunos nesta área do conhecimento, esforços têm sido feitos no sentido de identificar os principais gargalos do processo de aprendizagem e propor ações diferenciadas que entusiasmem e motivem os alunos no aprendizado de programação de computadores.

Dentro desse cenário, o uso de atividades práticas que explorem a criatividade dos alunos nas diferentes possibilidades de construir sistemas, sejam por meio de técnicas lúdicas ou conectando dispositivos simples diretamente a componentes de hardware e software, se apresenta como a estratégia motivacional mais adequada para manter o interesse dos alunos nos conteúdos fundamentais

Nessa linha de raciocínio, este trabalho avalia a utilização de uma metodologia de aprendizado híbrida com ferramentas síncronas e assíncronas e atividades práticas complementares baseadas na plataforma Arduino, Figura 4.1 


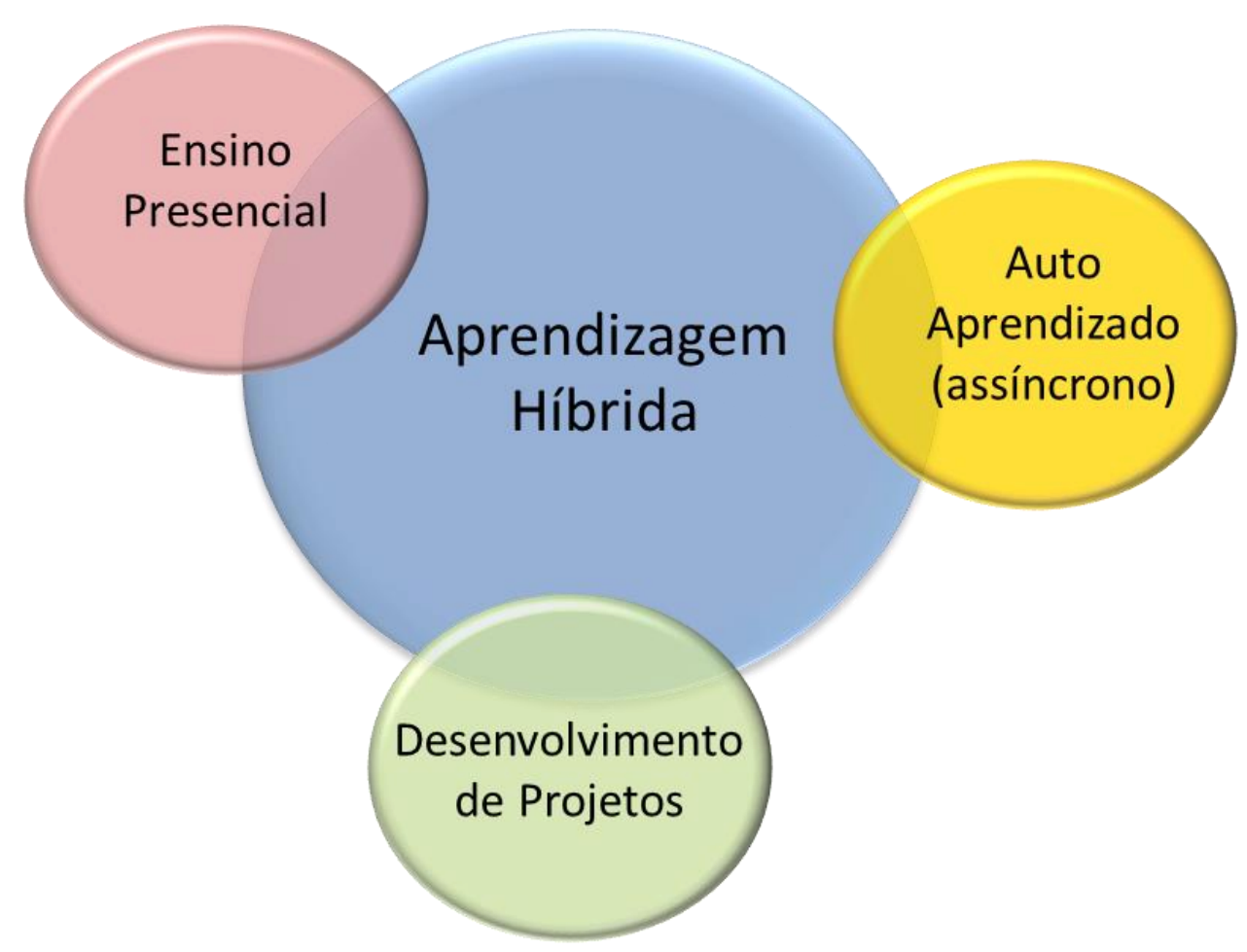

Figura 4.1. Modelo de Aprendizagem Híbrida proposto

Essa metodologia foi aplicada na disciplina WEB II, onde o aprendizado é associado a práticas experimentais utilizando a Plataforma Arduino. Para se ter uma ideia da importância da disciplina e em que momento do curso ela é ministrada, Tabela 4.1 mostra a ementa da disciplina onde é possível observar a inclusão de projetos com a plataforma arduino.

Tabela 4.1 Quadro 4.1 - Ementa da disciplina WEB II

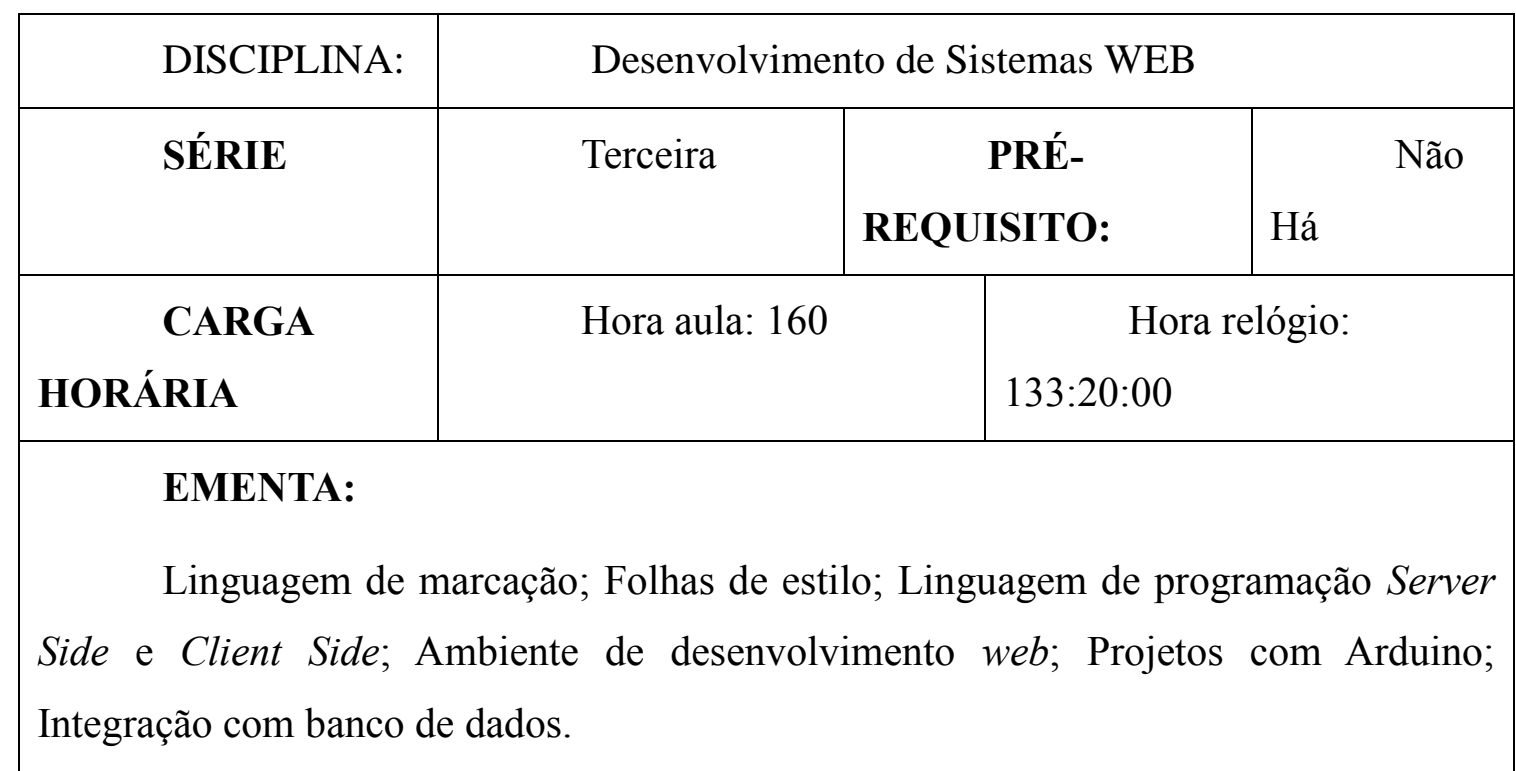




\section{BIBLIOGRAFIA BÁSICA:}

\section{GILMORE, W.J. Dominando o PHP e o MySQL: Do Iniciante ao}

profissional. Rio de Janeiro: Alta Books, 2010.

MACORATTI, José Carlos. Asp, ado \& Banco de Dados na Internet. 2. ed: Visual Books.

NIEDERAUER, Juliano. Desenvolvendo WEB sites com PHP. 2. ed: Novatec, 2011.

RAY, Erik T. Aprendendo XML.: Campus, 2001.

\section{BIBLIOGRAFIA COMPLEMENTAR:}

BELL, Gavin. Criando Aplicações para Redes Sociais: Novatec, 2010. BONIFÁCIO JÚNIOR, José Maurício di. Asp.net: Fundamentos para o desenvolvimento de aplicações web em plataforma .NET: Berkeley, 2001. DIAS, Cláudia. Usabilidade na WEB: Criando portais mais acessíveis. 2. ed. Rio de Janeiro: Alta Books, 2007.

www.arduino.com acesso em 2014.

Monk,Simon. Programação com Arduino: Começando com Sketches/Simon Monk;tradução: Anatólio Laschuk. - Porto Alegre: Bookman, 2013.

\subsection{HISTÓRICO DA PLATAFORMA ARDUINO}

O Arduino surgiu em 2005, na Itália, com um professor chamado Massimo Banzi, que queria ensinar eletrônica e programação de computadores a seus alunos de design, para que eles usassem em seus projetos de arte, interatividade e robótica. Porém, ensinar eletrônica e programação para pessoas que não são da área não era uma tarefa simples, e outra dificuldade era a inexistência de placas poderosas e baratas no mercado.[27]

Foi pensando nisso que Massimo e David Cuartielles decidiram criar sua placa própria, com a ajuda do aluno de Massimo, David Mellis, que ficou responsável por criar a linguagem 
de programação do Arduino. Várias pessoas conseguiram utilizar o Arduino e fazer coisas incríveis, surgindo assim essa febre mundial da eletrônica. [27]

\subsection{PLATAFORMA ARDUINO}

Arduino é uma placa de controle de entrada de dados (IN), como sensores, e saída de dados (OUT), como motores e leds, com cristal oscilador de $16 \mathrm{Mhz}$, um regulador de tensão de $5 \mathrm{~V}$, botão de reset, plugue de alimentação, pinos conectores, e alguns LEDs para facilitar a verificação do funcionamento. A porta USB já fornece alimentação enquanto estiver conectado ao computador, e a tensão de alimentação quando desconectado pode variar de $7 \mathrm{~V}$ a $12 \mathrm{~V}$, graças ao regulador presente na placa. No Arduino, informações ou ordens são transmitidas de um computador para a placa através de Bluetooth, wireless, USB, infravermelho, etc. Essas informações devem ser traduzidas utilizando a linguagem Wiring baseada em C/C++. [28]

Arduino é um projeto que engloba software e hardware e tem como objetivo fornecer uma plataforma fácil para prototipação de projetos interativos, utilizando um microcontrolador. Ele faz parte do que chamamos de computação física: área da computacão em que o software interage diretamente com o hardware, tornando possível integracão fácil com sensores, motores e outros dispositivos eletrônicos.

O Arduíno é descrito pelos seus construtores como "uma plataforma de prototipação de fonte aberta, baseada em hardware e software fácil de utilizar. É planejada para artistas, designers, hobbystas e qualquer um interessado em criar ambientes ou objetos iterativos" [28]

As suas características, e uma ativa comunidade na internet, lhe têm garantido um forte crescimento na sua base de usuários. O site do Arduino, em http://arduino.cc oferece um excelente suporte ao sistema, com seções de referência, e inclui uma seção denominada "Playground", em que conceitos de programação e de circuitos são explicados de forma simplificada. [28]

Uma placa de Arduino é construída sobre um microcontrolador e um dispositivo de interface com o PC, para programação e comunicação. Nas versões mais populares da placa, estes componentes são, respectivamente, um AVR ATmega328, da ATMEL, e o CI FT232, da FTDI. O projeto da placa é bastante simples, e a maior parte da mesma ocupada pela conexão dos pinos do microcontrolador a um conjunto de conectores dispostos de uma forma bem 
definida, segundo o padrão do Arduino. Um outro aspecto importante é que o padrão Arduino permite a conexão de módulos periféricos, denominados "shields" (“escudos"), disponíveis comercialmente, para expansão do sistema, atendendo a uma grande variedade de aplicações. [28]

\subsection{TIPOS DE ARDUINO}

Em função da característica open source do projeto Arduino, muitos outros modelos da placa eletrônica surgiram desenvolvidos pela comunidade Arduino em todas as partes do mundo. Entre eles destaca-se as versões norte-americanas Boarduino e Roboduino, a canadense Freeduino e as brasileiras, Severino e Brasuino, [29] .Os principais modelos oficiais da placa eletrônica (hardware) do Arduino são mostrados na Tabela 4.2. A seguir uma breve descrição de cada modelo é apresentada.

\subsubsection{Arduino Uno}

Possui um bom número de portas disponíveis, e grande compatibilidade com os shilds disponíveis no mercado. Possui processador ATMEGA328, 14 portas digitais, sendo que 6 delas podem ser usadas como saídas PWM, e 6 portas analógicas. A alimentação (selecionada automaticamente), pode vir da conexão USB ou do conector para alimentação externa (recomendável 7 a 12V). [28]

Esta placa Arduino, com microcontrolador ATMEGA2560 e 54 portas digitais, das quais 15 podem ser usadas como PWM, além de 15 portas analógicas. Clock de 16Mhz, conexão USB e conector para alimentação externa. Ideal para projetos mais elaborados que exijam grande número de entradas e saídas. A figura 4.2 mostra o Arduino Uno. [28] 


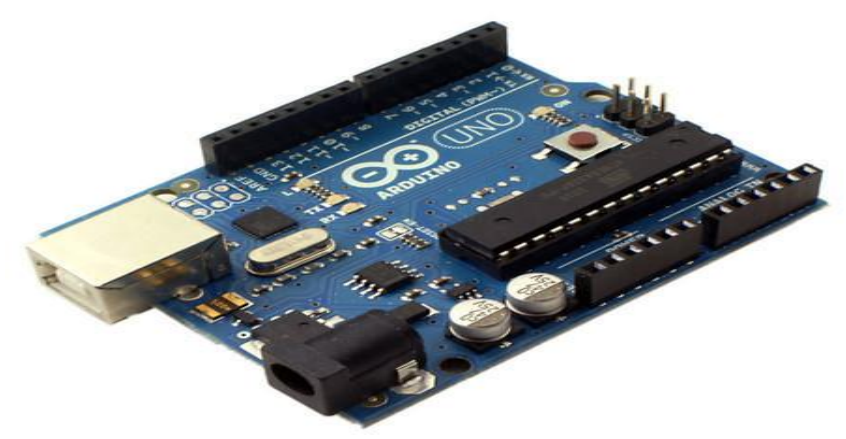

Figura 4.2: Arduino Uno

Fonte $-[28]$

\subsubsection{Arduino Mega ADK}

Esta placa possui uma conexão USB dedicada à ligação com dispositivos baseados em Android, como telefones celulares. Possui 54 porta digitais, das quais 15 podem ser usadas como PWM, 16 portas analógicas, 4 chips dedicados à comunicação serial, clock de 16 Mhz e conexão ao computador via USB. Também possui conector para alimentação externa. [28] Veja na figura 4.3 o Arduino Mega ADK

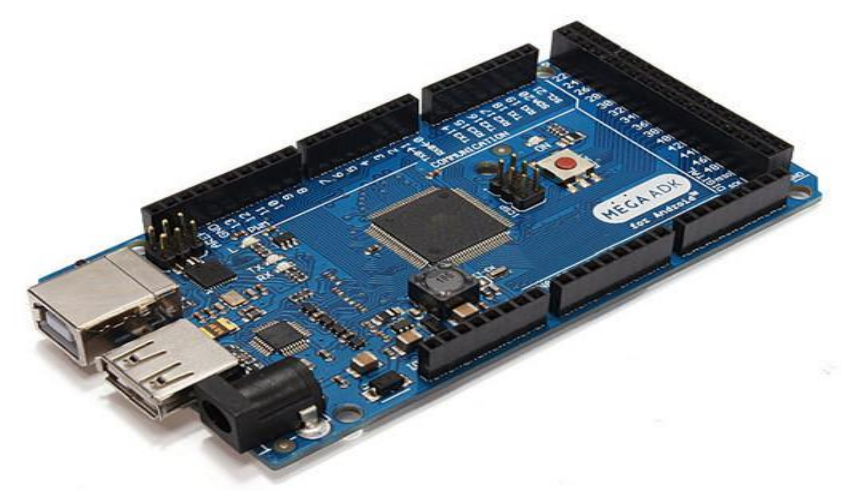

Figura 4.3: Arduino Mega ADK

Fonte $-[28]$ 


\subsubsection{Arduino Leonardo}

O Arduino Leonardo é uma placa de microcontrolador baseado Atmega32u4, possuindo 20 (vinte) portas digitais de entrada e saída, das quais 7 (sete) podem ser usadas como saídas PWM e 12 como portas analógicas. Possui clock de 16 (dezesseis) Mhz e conexão para alimentação externa. Diferenciando do Arduino Uno, possui concetor micro-usb para ligação ao computador. A figura 4.4 apresenta Arduino Leonardo. [28]

Outra característica dessa placa é o chip de conexão USB integrado ao microcontrolador, o que elimina a necessidade de um chip adicional de comunicação na placa, e permite que o Arduino Leonardo seja reconhecido pelo computador como se fosse um mouse ou um teclado, e não necessariamente como uma porta serial (também disponível). [28]

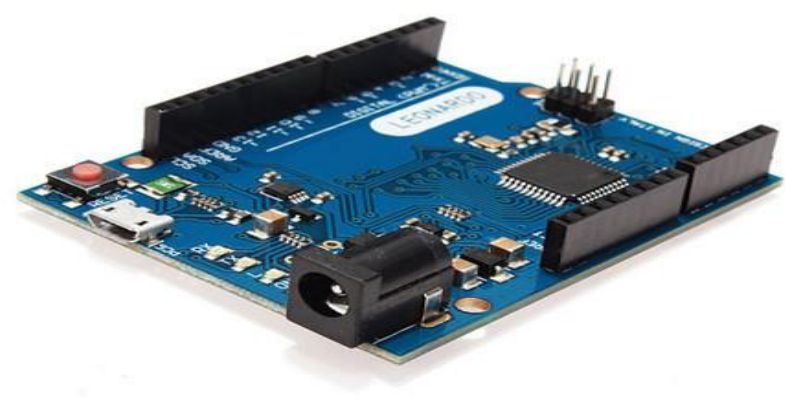

Figura 4.4: Arduino Leonardo

Fonte $-[28]$

\subsubsection{Arduino DUE}

Arduino Due é a placa com maior capacidade de processamento, baseada em microcontroladorARM de 32 bits e $512 \mathrm{~Kb}$ de memória totalmente disponível para programas e aplicações. O bootloader já vem gravado de fábrica em uma memória ROM dedicada. Possui 54 portas digitais, das quais 12 podem ser usadas como PWM e 12 portas analógicas. Possui também 4 chips controladores de portas serias, conexão USB e conector para alimentação externa. [28] 
As ligações desta placa exigem atenção pois as portas trabalham à 3,3 V (volts), o que pode comprometer o uso dos shields disponíveis no mercado, que geralmente trabalham com 5 V. A figura 4.5 mostra um Arduino Due.

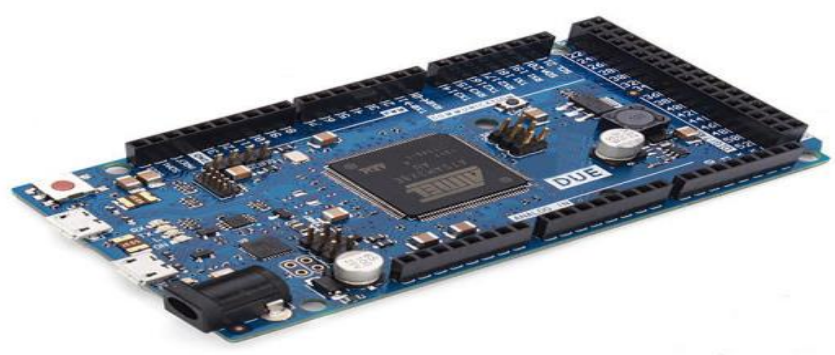

Figura 4.5 - Arduino Due

Fonte $-[28]$

\subsubsection{Arduino Nano}

Placa compacta baseada no microcontrolador Atmega328 (para placas Arduino Nano versão 3.x), ou ATmega168 (versão 2.x). Ao contrário das outras placas, não possui conector para alimentação externa, sendo alimentada por um conector USB Mini-B. Possui $32 \mathrm{~Kb}$ de memória (Nano versão 3.0), ou 16Kb (Nano versão 2.0), sendo que $2 \mathrm{~K}$ são usados pelo bootloader. Seu tamanho reduzido (4,3 de comprimento x 1,85 de largura) faz dessa placa uma opção para projetos compactos que exijam atualização constante de software. A figura 4.5 apresenta o Arduino Nano [28]

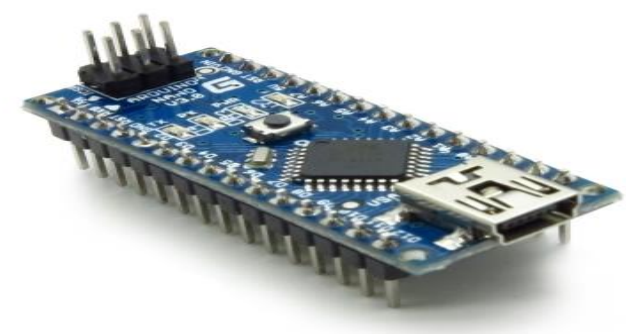

Figura 4.6 - Arduino Nano

Fonte - [28] 


\subsubsection{Arduino Pro Mini}

Placa compacta, ideal para projetos permanentes e que não necessitem de grande poder de processamento ou constante atualização. $\mathrm{O}$ microcontrolador utilizado por esta placa é o ATmega168 que, dependendo da versão da placa, roda à $8 \mathrm{Mhz}$ ( placa versão $3.3 \mathrm{~V}$ ) ou $16 \mathrm{Mhz}$ (placa versão 5V). Possui 14 portas digitais, sendo que 6 podem ser usadas como PWM, e 8 portas analógicas. Não possui conexão USB ou conector para alimentação externa. Para comunicação com o computador, pode ser adquirido um módulo USB separadamente, ou utilizada uma placa Arduino para programação. A figura 4.7 mostra o Arduino PRO MINI. [28]

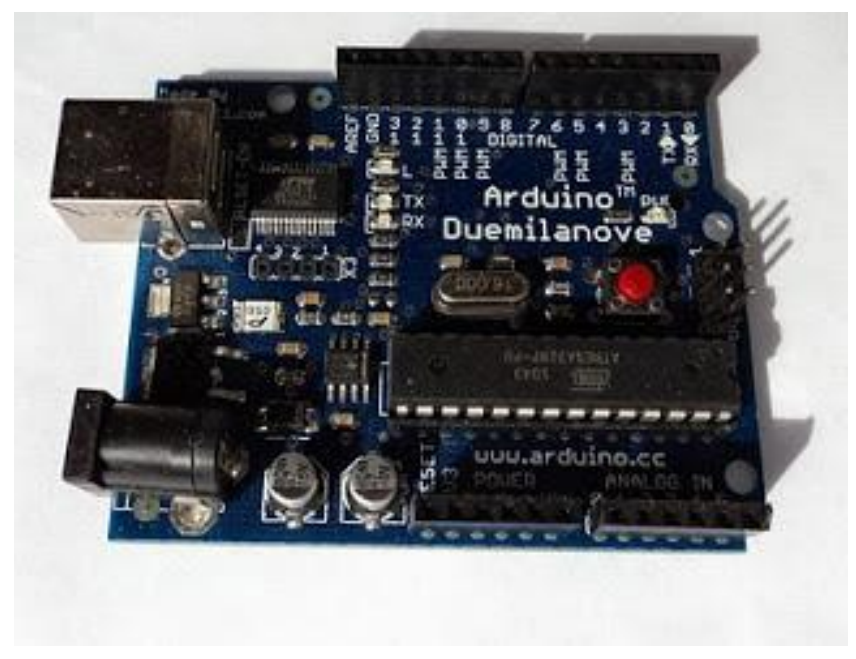

Figura 4.7 - ARDUINO PRO MINI

Fonte $-[28]$

\subsubsection{Arduino Esplora}

Com o formato parecido com o de um controle de videogame (e até pode ser usado como um, dependendo da criatividade do desenvolvedor), o Arduino Esplora é uma placa diferente de todas as outras da família, principalmente por possuir diversos sensores na sua construção. Nessa placa vem embutido um buzzer, um joystick, um potenciômetro deslizante, um sensor de temperatura, um acelerômetro, um led RGB, um sensor de luz (LDR), 4 push - buttons e um 
microfone. Além de tudo isso, ainda possui um soquete para tela LCD. A figura 4.8 mostra o Arduino Esplora. [28]

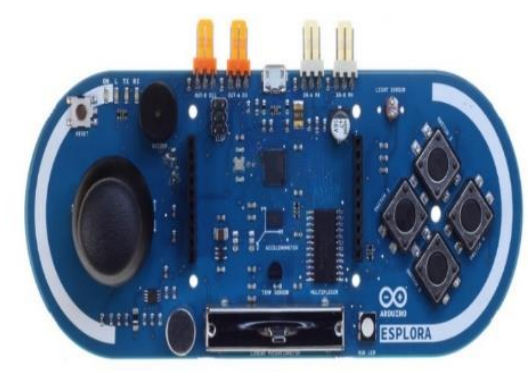

Figura 4.8 - Arduino Esplora

Fonte - [28]

\subsection{AMBIENTE DE DESENVOLVIMENTO DO ARDUINO (IDE)}

O ambiente de desenvolvimento do Arduino oferece uma interface de usuário simplificada. A linguagem do padrão, denominada Wiring, é derivada de $\mathrm{C}++$, por expansão de seus recursos. Para utilizar a plataforma Arduino é necessário fazer o download do Ambiente de Desenvolvimento do Arduino. [28]

As figuras 4.9, 4.10 e 4.11 mostra o Arduino, algoritmo e a codificação em linguagem $\mathrm{C}$ de um programa bastante simples, para acender e apagar alternadamente o led do pino 13 da placa.

Para construir o circuito, colocou-se um resistor de 220 ohm no pino 13. Em seguida, anexou a perna positiva (chamado ânodo) de um LED para o resistor. Anexou a perna negativa (chamado de cátodo) para o solo. Em seguida conectou-se a placa arduino no computador, iniciou o programa Arduino, e digitou o código abaixo. [28] 


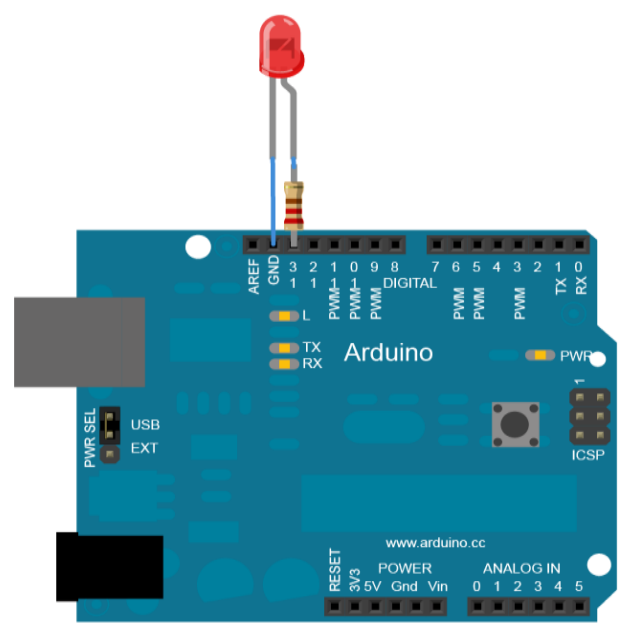

Figura 4.9: Led ligado a placa Arduino

Fonte - [28]

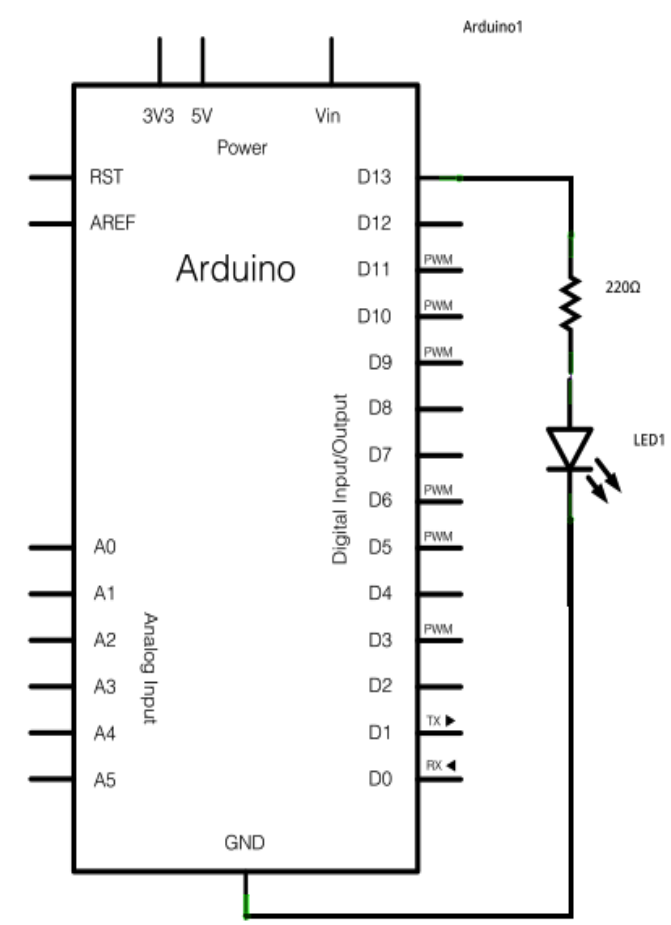

Figura 4.10: Esquemático do circuito.

Fonte - [28] 


\section{/*}

Piscar

Acende um LED por um segundo, então fora por um segundo, repetidamente.

Este exemplo de código é de domínio público.

* I

void setup () \{

// Inicializa o pino digital como uma saída.

// Pin 13 tem um LED conectado na maioria das placas Arduino:

pinMode (13, OUTPUT);

\}

void loop () \{

digitalWrite (13, HIGH); // set o LED

delay (1000); / esperar / por um segundo

digitalWrite (13, LOW); // definir o off LED

delay (1000); / esperar / por um segundo \}

Figura 4.11 - Programaçao LED.

Fonte - [28] 


\section{IMPLANTAÇÃO DO BLENDED LEARNING NA DISCIPLINA WEB II}

Para a melhor compreensão do processo de utilização do Blended Learning o capítulo inicia-se mostrando como a disciplina era tradicionalmente lecionada e como foi modificada pela utilização do Blended Learning. Em seguida detalhamentos das atividades são apresentados.

\subsection{A DISCIPLINA WEB II MINISTRADA DE FORMA TRADICIONAL}

A disciplina de WEB II de acordo com o plano de ensino tem uma componente letiva teórica e uma componente letiva prática e tem como principais objetivos:

- Formar Técnico em Informática para uma atitude ética, humanística e responsável socialmente;

- Utilizar ambientes de desenvolvimento de sistemas, sistemas operacionais e banco de dados;

- Desenvolver web sites;

- Oportunizar o exercício e a ampliação da capacidade do estudante em utilizar linguagens e códigos próprios da sua área de atuação em situações sociais, de forma reflexiva e argumentativa;

- Promover eventos como seminários, exposições, workshop, divulgações de trabalhos científicos da área de informática, contribuindo para o envolvimento e participação crítica;

- Viabilizar a realização de pesquisas, experiências no ambiente real de trabalho, inclusive nas dependências da escola, como laboratório disponível para o aprendiz; 
Tabela 5.1 - Conteúdo programático e carga horária de cada atividade da disciplina:

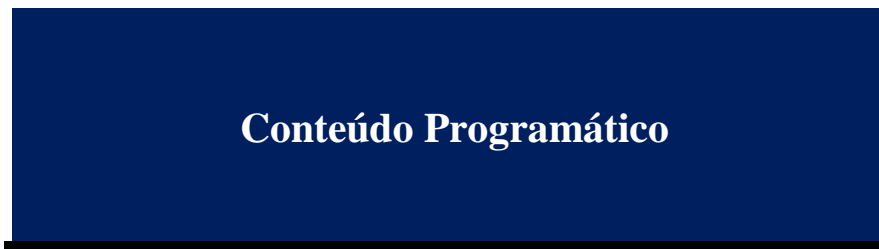

Linguagem de marcação

Folhas de estilo

Linguagem de programação Server Side e Client Side;

Ambiente de desenvolvimento web

Integração com banco de dados

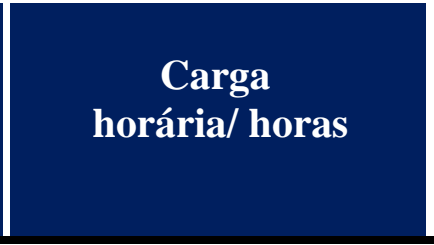

25

25

35

40

35

Na configuração tradicional a disciplina não apresentava ferramentas e formas que pudessem promover a aprendizagem centrada no aluno, estimular o trabalho em equipe, desenvolver a capacidade crítica e permitir a aprendizagem de forma interdisciplinar.

A metodologia de aprendizagem utilizada era baseada em um conteúdo bastante teórico acrescido de experimentos de laboratório pré-definidos, conforme ilustrado na Figura 5.1. Para a aferição do aprendizado eram feitas três avaliações: duas teórica, uma no meio do curso e outra após todo o conteúdo da disciplina ser ministrado, e uma avaliação prática, sobre as experiências de laboratório, efetuada no final da disciplina. 

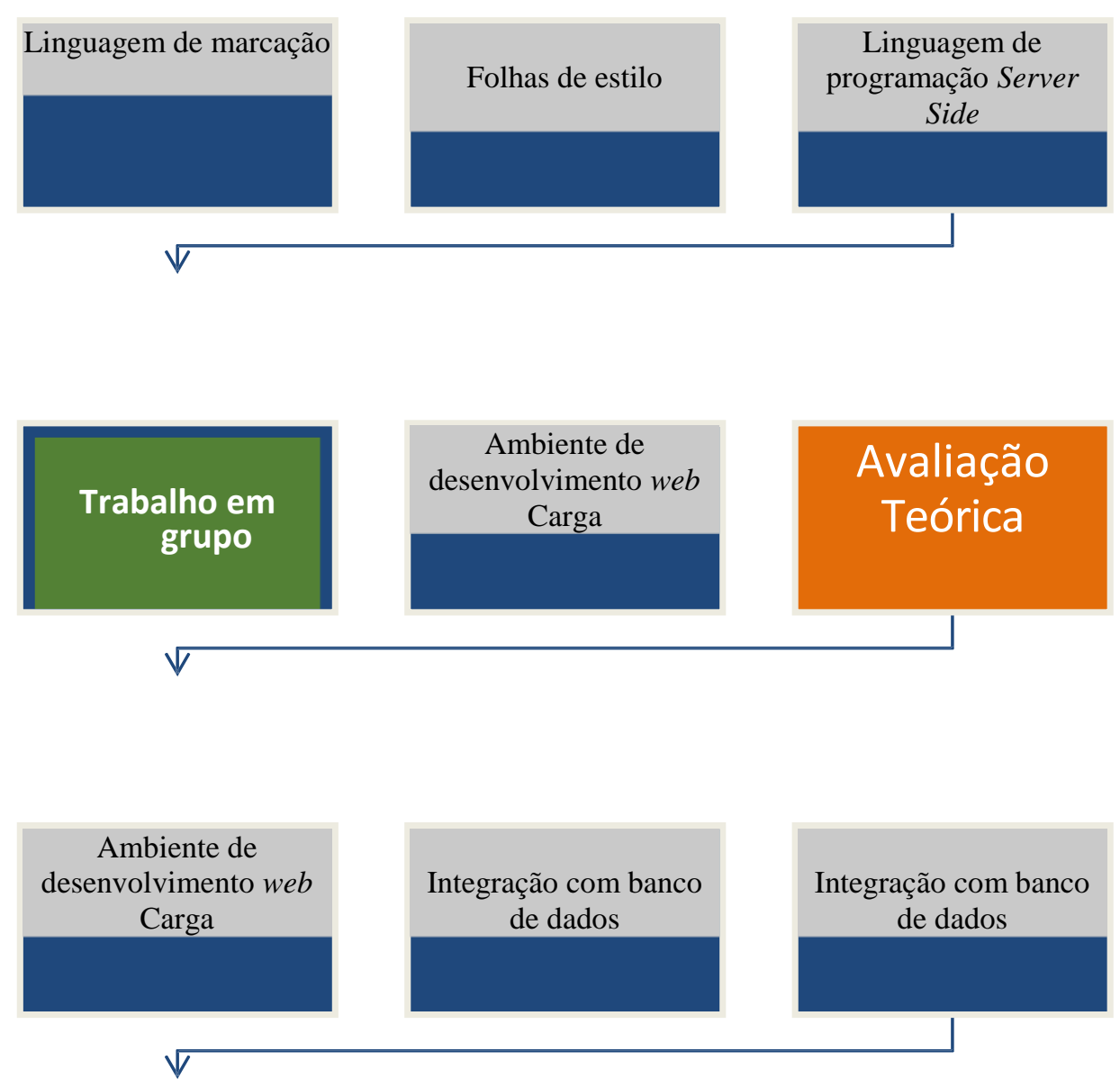

\section{Avaliação \\ Prática}

\subsection{IDENTIFICAÇÃO DO PERFIL DO ALUNO PARA A IMPLEMENTAÇÃO DO BL}

$\mathrm{Na}$ construção do modelo híbrido com a utilização de diferentes tecnologias, é fundamental se conhecer o perfil do aluno. Conhecendo o perfil do aluno é possível traçar uma estratégia pedagógica, apoiada em mídias adequadas, que explore melhor as aptidões do público alvo. Para isto, procurou-se levantar as características e necessidades dos alunos, bem como, verificar o grau de receptividade e familiaridade com as novas tecnologias. [30] 
Elaborou-se um questionário com 9 perguntas que foi aplicado na disciplina de programação WEB a um universo de 20 alunos. O questionário buscou alcançar uma radiografia sobre os estudantes, familiaridade com a tecnologia da informação, e motivação em relação ao ensino tradicional. O quadro 5.1 mostra o questionário utilizado e as respostas obtidas. .

\section{QUESTIONÁRIO - IDENTIFICAÇÃO DO ALUNO}

1 Idade: 15 anos $-1,16$ anos $-7,17$ anos $-9,18$ anos -3

2 Sexo: a) Feminino (11), b) Masculino (9)

3 Porque você escolheu Técnico em Informática

a) Identificava com a área de informática - 15

b) Outros -5

4 Você trabalha ou já trabalhou em algum lugar

a) $\operatorname{Sim}(13)$ b) Não (7)

5 Você tem computador

a) $\operatorname{sim}(16)$ b) não(4)

6 Você utiliza Internet

a) pouco (0) b) muito (2) c) sempre (18)

7 Você já participou de algum curso de treinamento por educação à distância
a) $\operatorname{sim}(3)$ b) não (17)

8 Você aprende nas aulas

a) $\operatorname{sim}(5)$ b) muito pouco (10) c) não (5)

9 Você toparia aprender a disciplina de programação WEB utilizando outros meios mesmo sabendo que você teria que estudar mais

a) $\operatorname{sim}(20)$ não (0)

Quadro 5.1 - Questionário sobre a radiografia dos alunos

Os dados são analisados e quando pertinente apresentados em forma de gráficos.

No universo analisado constatou-se que a faixa etária dos alunos está entre 15 e 18 anos, conforme mostra a figura 5.2 


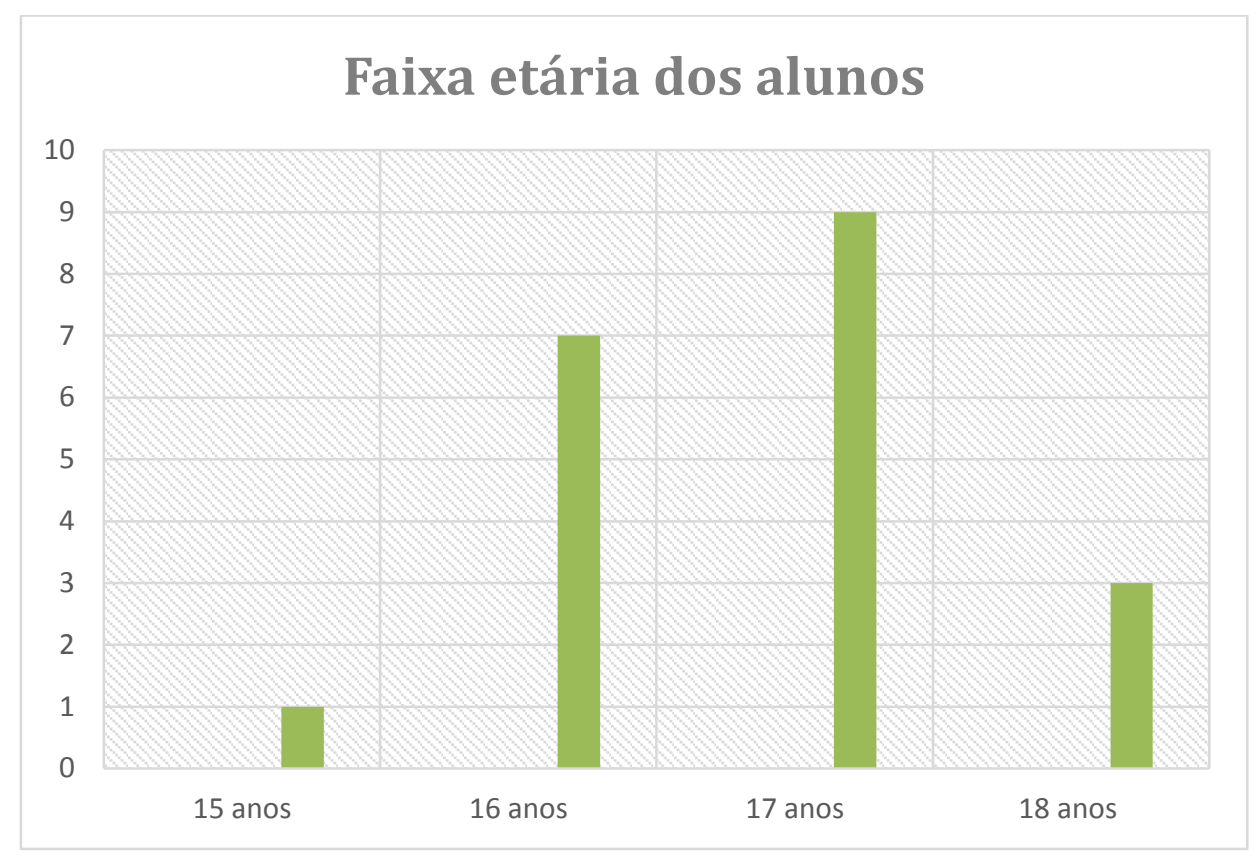

Figura 5.2 - Faixa etária dos alunos

Em relação ao gênero, $55 \%$ é do sexo feminino e $45 \%$ é do sexo masculino, figura 5.3

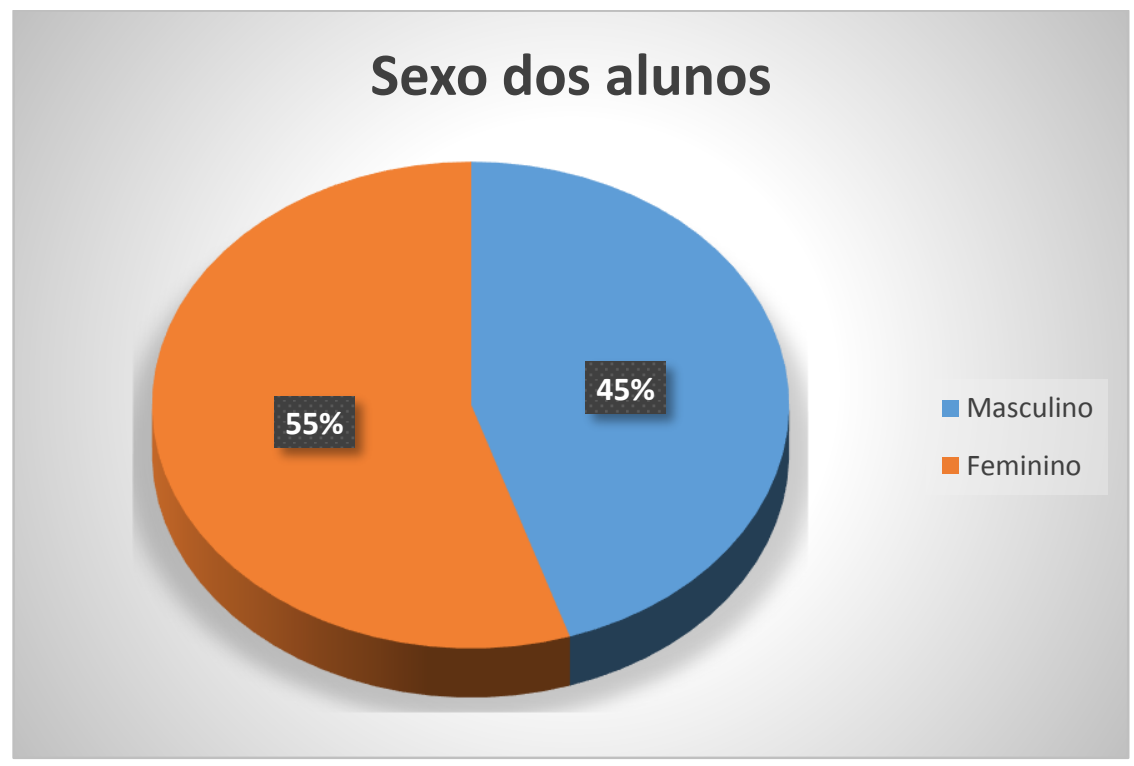

Figura 5.3 - Sexo dos alunos

$\mathrm{Na}$ enquete realizada verificou-se que a maioria dos alunos já trabalhou ou ainda trabalha, figura 5.4 


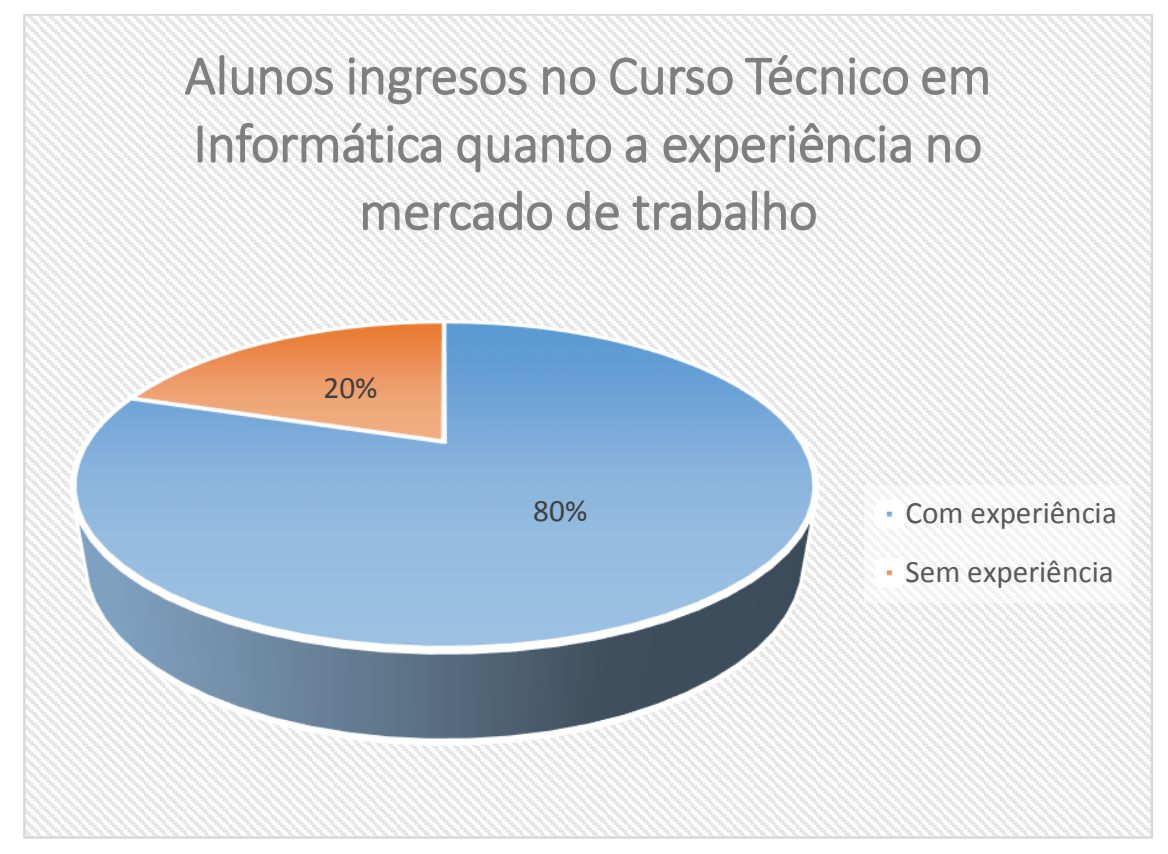

Figura 5.4 : Experiência no mercado de trabalho

Quanto ao uso de internet foi perguntado se eles utilizavam pouco, muito ou sempre. 18 (dezoito) alunos afirmaram que utilizam sempre e 2 (dois) utilizam muito, que significa que a totalidade tem familiaridade com alguma ferramenta associada a tecnologia da informação, figura 5.5 .

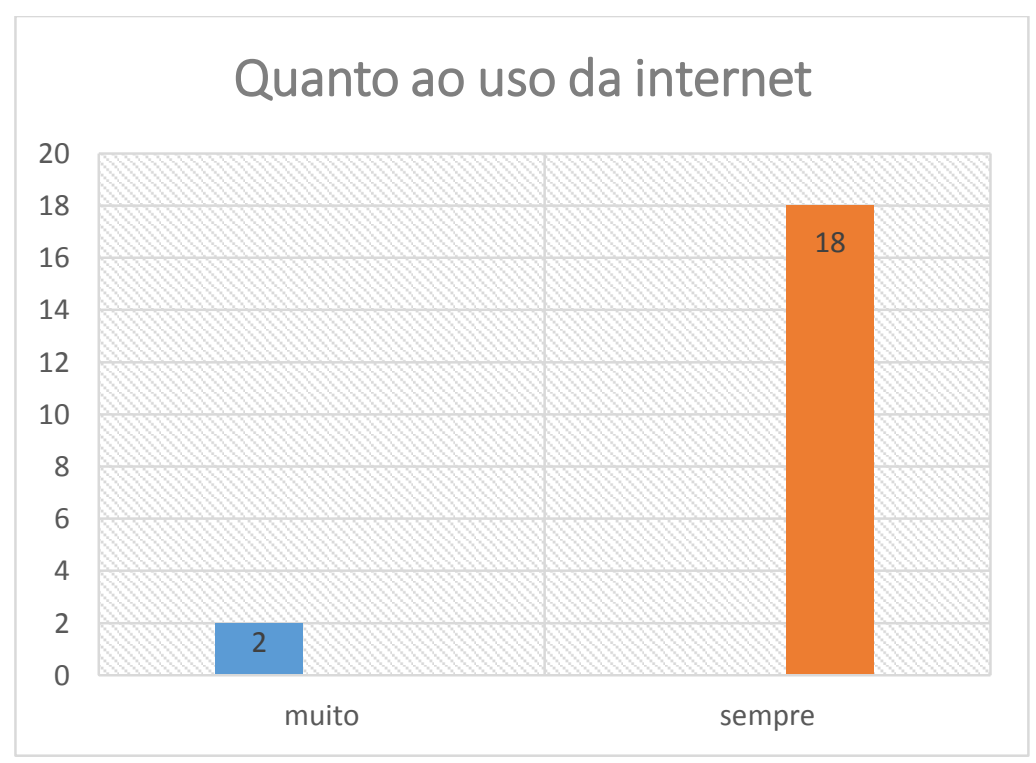

Figura 5.5 - Acesso a internet

Outra informação fundamental deduzida da pesquisa realizada é que $50 \%$ da turma aprende muito pouco em sala de aula, $25 \%$ consegue aprender em sala de aula e $25 \%$ não aprendem nada, figura 5.6. 


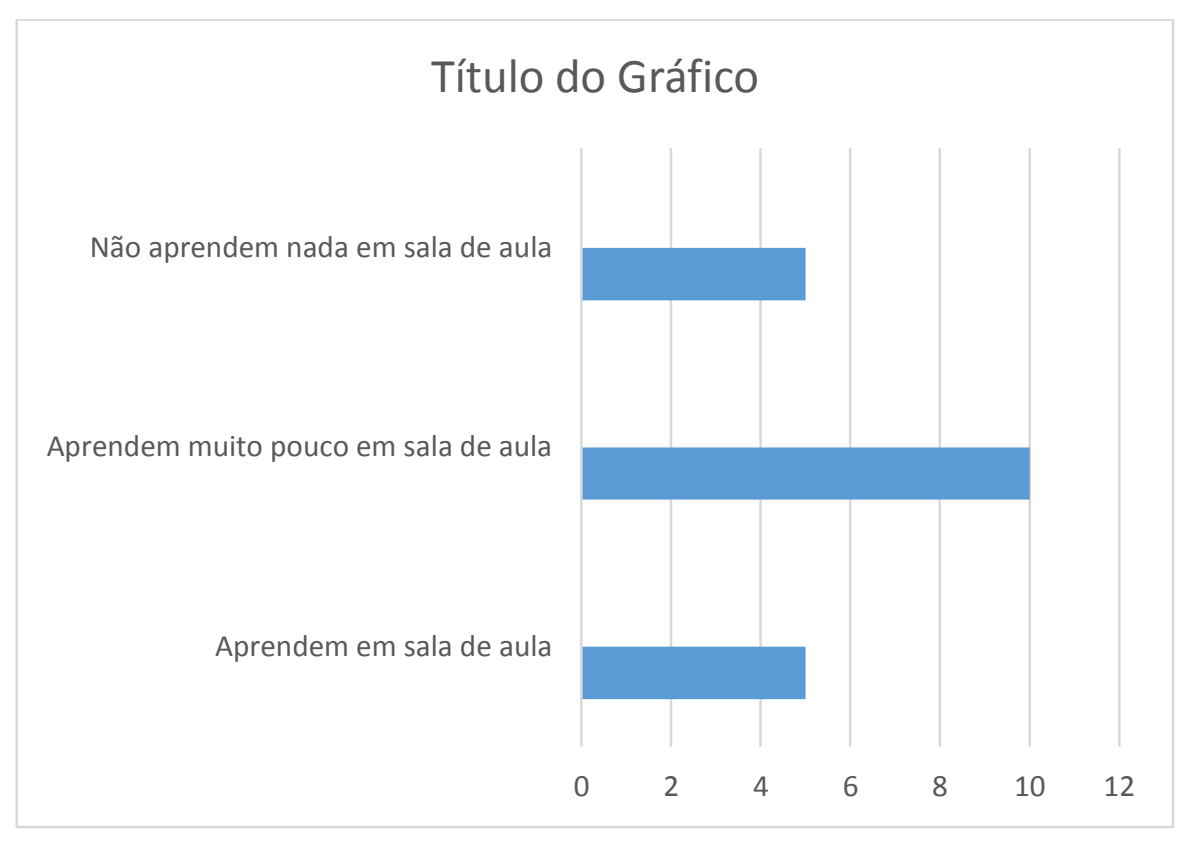

Figura 5.6: Ensino aprendizagem em sala de aula

Uma informação gratificante obtida com a pesquisa é que todos os alunos estariam dispostos a aprender programação WEB utilizando novas ferramentas mesmo que isso implique em uma maior carga de trabalho, figura 5.7.

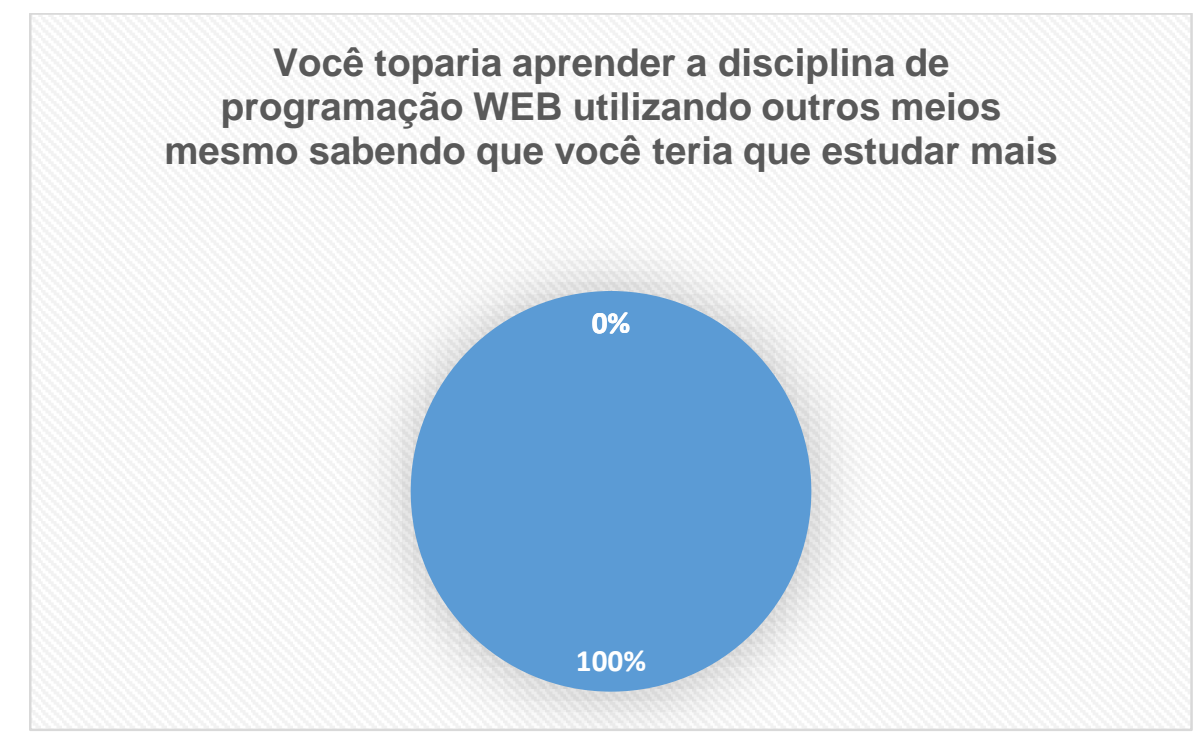

Figura 5.7: Outros meios de aprendizagem

Dos dados da pesquisa fica explicito a motivação dos alunos em relação a uma nova estratégia de aprendizado e a familiaridade dos mesmos com as tecnologias da informação. $\mathrm{O}$ acesso dos estudantes à computadores e o seu uso intensivo via internet, associado ao desejo de 
mudança em relação aos métodos de aprendizagem, permite planejar a disciplina utilizando um modelo híbrido de aprendizado com diferentes ferramentas. Além disso, esta maneira de ministrar a disciplina contribuirá na formação de profissionais da área de informática mais aptos e abertos a trabalharem de forma colaborativa, considerando as habilidades técnicas e não técnicas.

\subsection{PLANEJAMENTO DA DISCIPLINA}

Um dos objetivos de se conhecer o perfil dos alunos foi obter informações para se ter a certeza de que as tecnologias a serem utilizadas são propicias aos objetivos estipulados. A partir dessas informações é feito um planejamento prévio considerando sempre as possibilidades de interação (presencial ou à distância) que estimulem a cooperação mútua, seja aluno/aluno ou aluno/professor em um cenário onde as mais adequadas ferramentas virtuais e presenciais sejam utilizadas.

A metodologia desenvolvida para a disciplina está ancorada em um tripé tendo um projeto educativo como elemento central e eixo condutor da disciplina.

Em síntese a metodologia utilizada na disciplina “WEB II” é formada por:

1) Aulas expositivas para promover a interação do aluno com o conteúdo teórico da disciplina. As aulas têm como objetivo apresentar as potencialidades profissionais dos diferentes campos de atuação associados ao conteúdo programático da disciplina, expor e esclarecer conceitos, fornecer exemplos de aplicações práticas, definir o projeto, e ajudar na preparação e revisão de atividades.

2) Elaboração e apresentação de Projeto via Plataforma Arduíno, que utilize e ajude a consolidar os conceitos teóricos e estimule o desenvolvimento de atitudes e habilidades tais como, planejamento, trabalho em equipe, programação, criatividade, e comunicação escrita e oral.

3) Emprego de um Sistema de Gestão do Aprendizado (LMS, Learning Management System) para gerenciar as atividades desenvolvidas durante a disciplina, disponibilizar as ferramentas virtuais utilizadas, bem como, funcionar como um repositório das notas de aulas expositivas 
Portanto, o modelo ficou sistematizado em três ambientes intercomplementares, na forma de três módulos abrangendo atividades virtuais síncronas, atividades presenciais, e atividades virtuais assíncronas, respectivamente, Figura 5.8

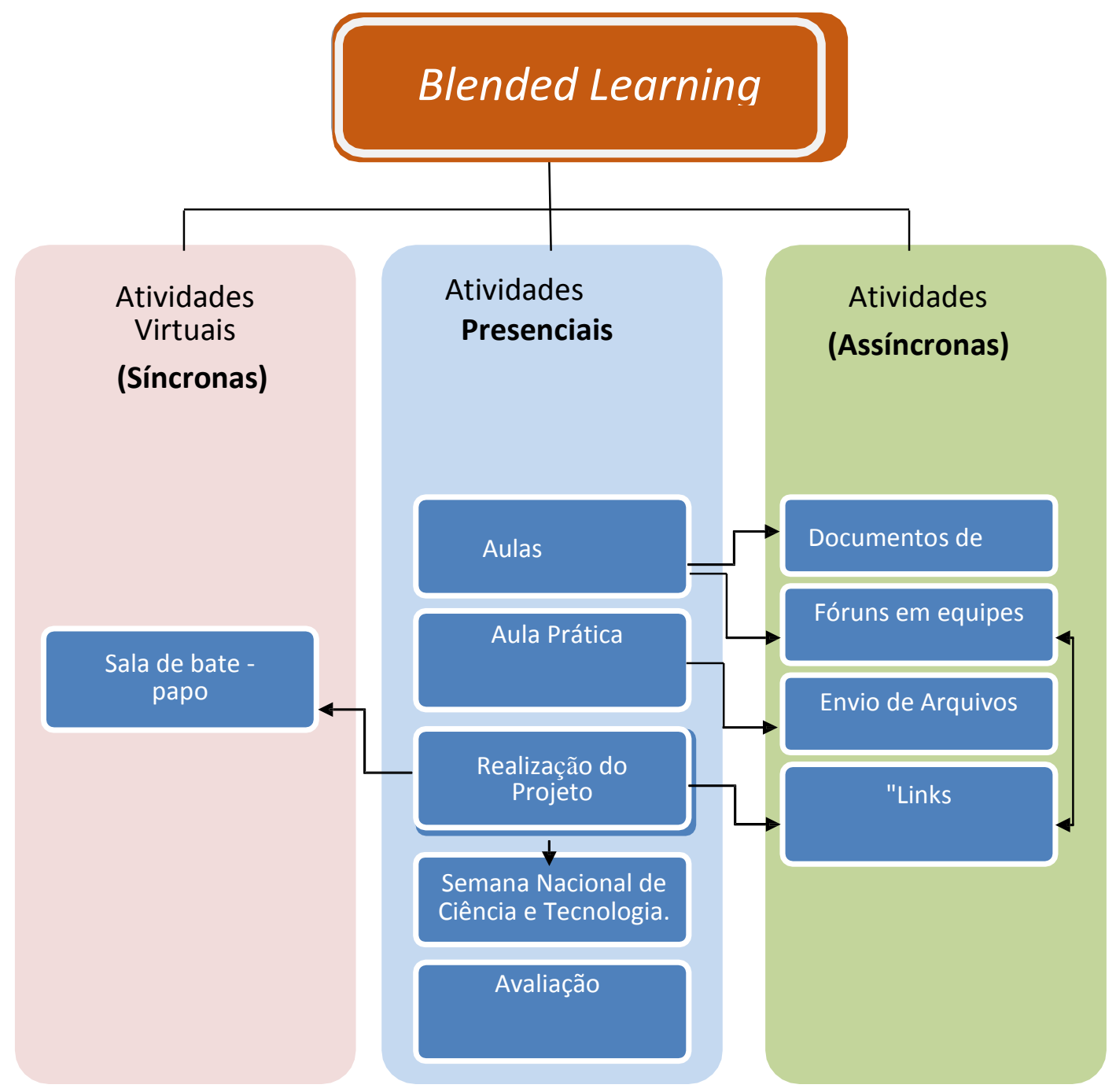

Figura 5.8 -Modelo de Aprendizagem Híbrida utilizado na disciplina WEB II

Quanto ao aspecto didático-pedagógico optou-se pelo modelo sugerido por Trindade, 2002, onde o desenvolvimento dos módulos é pautado por requisitos que favorecessem o aprendizado do aluno, conforme ilustrado na Quadro 5.2. 


\begin{tabular}{|c|l|}
\hline \multicolumn{1}{|c|}{ REQUISITOS } & \multicolumn{1}{c|}{ ESTRATÉGIA } \\
\hline Autonomia & $\begin{array}{l}\text { Houve preocupação em desenvolver um ambiente em } \\
\text { que o aluno tivesse facilidade de uso com adequada } \\
\text { interação com os objetos do ambiente. }\end{array}$ \\
\hline Maturação & $\begin{array}{l}\text { Conhecendo o perfil do público alvo, procurou-se } \\
\text { criar situações que explorassem os conhecimentos } \\
\text { e habilidades dos alunos. }\end{array}$ \\
\hline Disponibilidade & $\begin{array}{l}\text { Estabeleceram-se prazos flexíveis para o aprendizado } \\
\text { de cada tópico, respeitando a disponibilidade de cada } \\
\text { aluno. }\end{array}$ \\
\hline Interatividade & $\begin{array}{l}\text { O estudo de cada tópico foi planejado de maneira a } \\
\text { respeitar o ritmo de aprendizagem de cada aluno, } \\
\text { permitindo-lhe interagir com o conteúdo quantas } \\
\text { vezes achar necessário. }\end{array}$ \\
\hline $\begin{array}{l}\text { Aprendizagem } \\
\text { colaboratividade }\end{array}$ & $\begin{array}{l}\text { Estruturou-se a construção do conhecimento a } \\
\text { partir de aulas expositivas e da elaboração de um } \\
\text { projeto utilizando a Plataforma Arduíno. }\end{array}$ \\
\hline $\begin{array}{l}\text { Definiu-se que as atividades seriam realizadas em } \\
\text { trabalhos cooperativos entre pares visando o } \\
\text { desenvolvimento das habilidades transversais, tais } \\
\text { como, liderança e trabalho em equipe. }\end{array}$ \\
\hline
\end{tabular}

Quadro 5.2 - Requisitos básicos no desenvolvimento dos Módulos

$$
\text { Fonte }-[3]
$$

\subsection{DINÂMICA DA DISCIPLINA}

A abordagem da disciplina, conforme apresentada no item anterior foi feita com base em atividades presenciais e virtuais que englobaram diversos aspectos relacionados ao trabalho em equipe, aos conhecimentos sobre o curso técnico em Informática e as áreas de atuação correlatas.

O sistema Moodle, uma bem conhecida plataforma de Gestão de Aprendizagem (LMS Learning Management System ou AVA - Ambiente Virtual de Aprendizagem) que possibilita e permite a gestão de atividades pedagógicas de uma disciplina foi a principal ferramenta utilizada nas atividades virtuais síncronas e assíncronas.

O principal objetivo do Moodle na disciplina de Programação WEB foi promover a capacidade de comunicação escrita, gestão do tempo, trabalho em equipe. Com o Moodle foram compartilhadas matérias de estudo, feitas discussões online, efetuados testes e avaliações. Além disso, foram realizadas diversas pesquisas de opinião. 
A Figura 5.9 mostra a tela principal do Moodle customizado para o IFNMG onde a disciplina WEBII está hospedada.
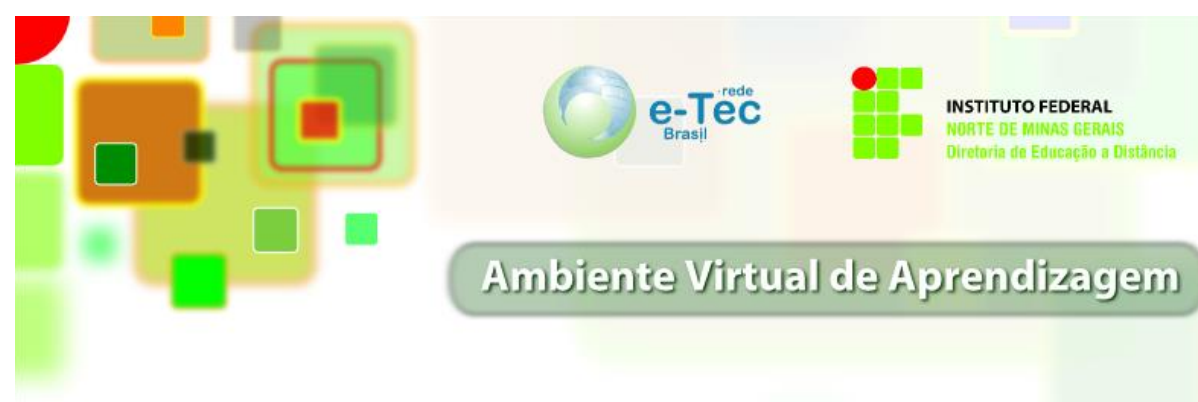

Fig. 5.9 Tela Principal do Moodle da IFMNG

A seguir as atividades inclusas nos três segmentos que compõem a proposta metodológica da disciplina, são descritas.

\subsubsection{Atividades Virtuais (Síncronas)}

As atividades virtuais (síncronas), são realizadas em tempo real, e por ser uma ferramenta interativa desperta motivação e interesse nos alunos.

Como atividade síncrona os orientadores criaram no Moodle uma sala de bate papo. Através da sala de bate papo as equipes e seus orientados reuniam-se mensalmente para compartilhar informações e analisar o desenvolvimento e andamento do projeto.

As Atividades virtuais (síncronas) tiveram como objetivo desenvolver capacidade de comunicação, trabalho em equipe e assegurar o bom andamento do projeto.

\subsubsection{Atividades Virtuais ((Assíncronas)}

As atividades virtuais assíncronas foram suportadas por três diferentes ferramentas tecnológicas: Moodle, Google Docs e Whatsapp, conforme ilustrado na Figura 5.10. As ferramentas foram utilizadas de maneira complementar cobrindo os vários itens do plano de ensino proposto. A seguir são descritas as atividades realizadas em cada uma das plataformas 


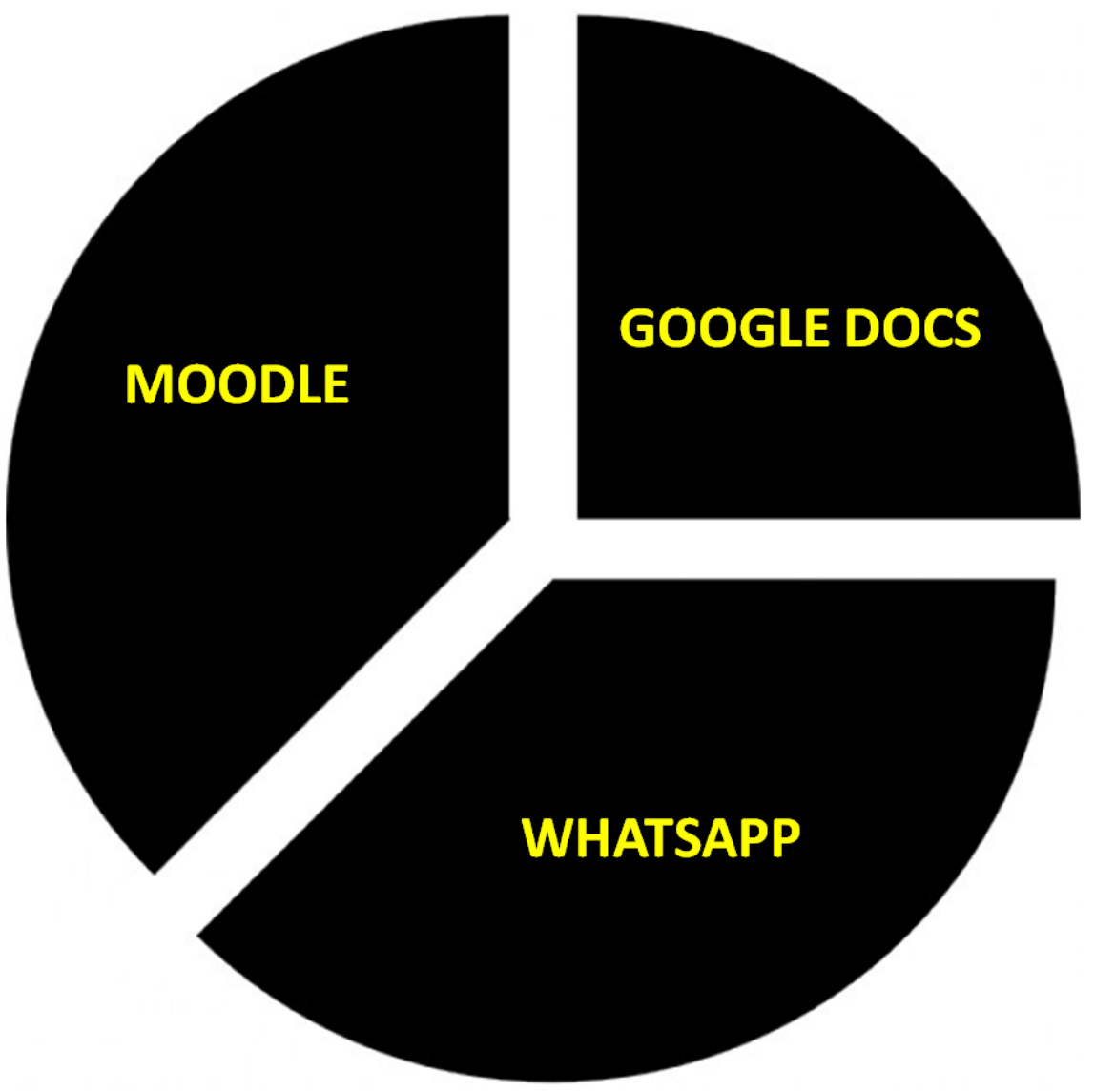

Fig. 5.10 - Ferramentas Tecnológicas utilizadas nas atividades virtuais assíncronas

\section{UTILIZAÇÃO DO MOODLE}

Com ajuda da plataforma Moodle, foram realizadas as seguintes atividades: Fórum em Equipe, Envio de Arquivos, Questionários e Linjks para outros sites, conforme ilustrado na Figura 5.11.

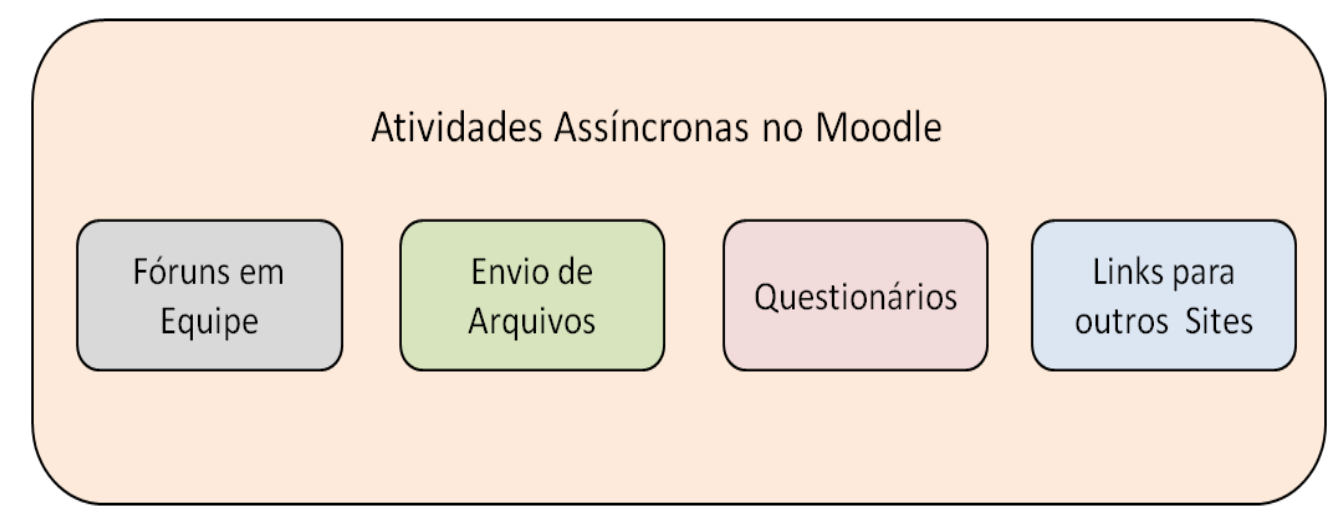

Figura 5.11 - Atividades Assíncronas feitas através do Moodle.

A seguir essas atividades são descritas: 


\section{Fóruns em equipe}

Os fóruns são um recurso que serve de ponte na construção do conhecimento entre o professor e o aluno, base para aprendizagem assíncrona, dentro de uma abordagem colaborativa, permitindo a interação aluno-aluno e aluno-professor. [3]

A Figura 5.12, mostra os diversos fóruns criados durante a disciplina.

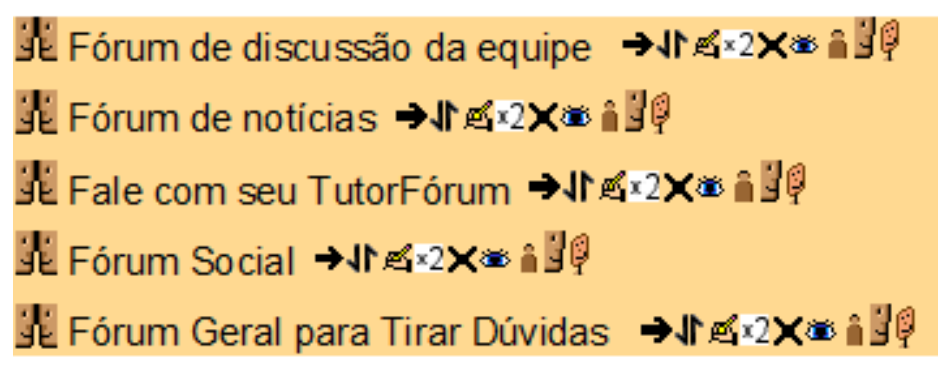

Figura 5.12: Fórum da disciplina de Programação WEB

Os fóruns foram estruturados para serem desenvolvidos entre as equipes sendo uma atividade de grande interesse dos alunos por permitir inserir ou comentar o tema em debate.

A utilização dos fóruns de discussões agrega vantagens no processo de aprendizagem, pois permite que os alunos coloquem questões e que elas lhes sejam respondidas, ajuda ultrapassar o isolamento dos alunos, favorece a interação, permite ao professor seguir a evolução do aluno, pode ajudar a manter discussões no caminho certo, permite que os alunos tenham tempo para formular questões e respostas e são um bom meio para variar a apresentação da informação. [31]

\section{Envio de arquivos}

Todas as aulas presenciais foram postadas no Moodle no formato do Adobe Acrobat (pdf). Essa atividade foi criada com o intuito de disponibilização das aulas ministradas. Sempre antes do início de algum novo tópico os alunos eram convidados a acessar o Moodle para fazer o download do material e conhecer o assunto a ser trabalhado. Através desse material os alunos puderam construir seu próprio conhecimento sobre o assunto em tempo e espaço 
determinados por eles, através do reuso e atualização do material didático de maneira simples e rápida.

\section{Questionários}

Esse recurso foi utilizado para duas finalidades distintas. Em uma primeira etapa algumas avaliações foram efetuadas, para verificar o grau de entendimento e discernimento do aluno em relação ao conteúdo que estava sendo ministrado.

Em um segundo momento utilizou-se o questionário para uma auto avaliação levando em consideração o aluno, o professor, o conteúdo da disciplina e a metodologia utilizada.

\section{Links para outros Sites}

Com essa ferramenta foi possível listar diversos sites que aboprdavam assuntos correlatos. Esse instrumento permitiu que os alunos fizessem a escolha sobre a melhor maneira, sob o ponto de vista de cada um deles, de aplicar e explicar os conhecimentos recentemente adquiridos.

\section{UTILIZAÇÃO DO GOOGLE DOCS}

O Google Docs é um pacote de aplicativos do Google, que funciona totalmente on-line diretamente no browser. Os aplicativos são compatíveis com o Microsoft Office e o OpenOffice.org, e atualmente compõe-se de um processador de texto, um editor de apresentações e um editor de planilhas. Alguns dos recursos mais peculiares é a portabilidade de documentos, que permite a edição do mesmo documento por mais de um usuário, bem como o recurso de publicação direta em blog. Os aplicativos permitem a compilação em PDF. [32]

O Google Docs permitiu as equipes trabalharem com documentos de texto, onde cada equipe publicava on-line versões dinâmicas ou estáticas dos documentos relacionados ao projeto, além das permissões de edição para determinados membros da equipe, enquanto mantinha outros apenas como revisores, sem poderes de edição.

Através do Google Docs os alunos desenvolveram seus planejamentos e atividades de forma colaborativa. Os alunos criaram uma conta no Gmail e em seguida começaram a compartilhar os arquivos do projeto de forma colaborativa entre os membros da equipe. 


\section{UTILIZAÇÃO DO WHATSAPP}

WhatsApp é um aplicativo de mensagens multiplataforma que permite trocar mensagens, mídias, áudios e ligações pelo celular. O usuário ainda pode criar grupos e enviar mensagens ilimitadas.

O aplicativo trouxe de novo à agilidade na troca de mensagens pelo celular pode ajudar a levar discussões para fora da sala e para esclarecer dúvidas pontuais dos alunos. A Figura 5.13 imagem do whatsapp. [33]

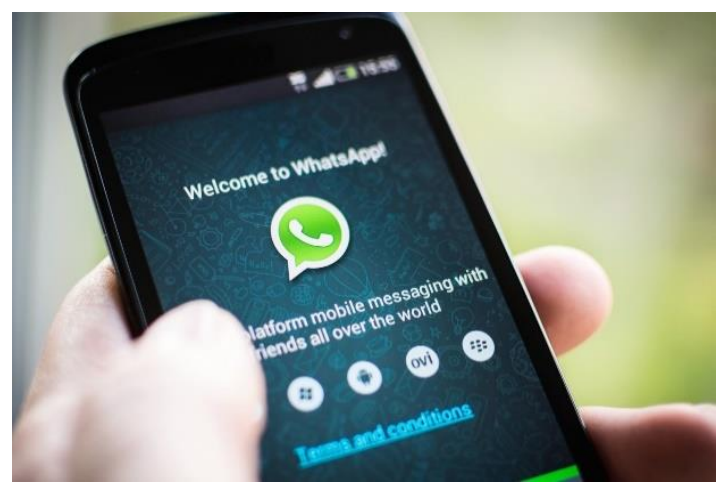

Figura 5.13 - WhatsApp

Cada equipe tinha seu grupo no Whatsapp, onde os resultados e comentários dos estudos individuais eram compartilhados e reuniões agendadas.

\subsubsection{Atividades Presenciais (face-to-face)}

O conteúdo da disciplina de WEB II foi distribuído na parte teórica e prática. As aulas presenciais foram ministradas semanalmente e os alunos tiveram conhecimento do conteúdo programático da disciplina por meio dos planos de ensino e aula, da bibliografia básica e dos métodos de avaliação a serem adotados.

\section{Aulas Teóricas}


Na parte teórica da disciplina foi desenvolvido os conceitos de cada um dos tópicos presentes no conteúdo programático. Por meio das aulas teóricas ensinou-se todos os conceitos necessários para o desenvolvimento dos exercícios desenvolvidos no laboratório de informática. Após o término das aulas eram criados os fóruns de discussões para que os alunos pudessem aprimorar o assunto abordado.

\section{Atividades no Laboratório de Informática}

Na parte prática foi desenvolvido projetos em grupo no laboratório de informática. Os alunos conheceram a ferramenta, onde foram apresentadas as funções e funcionalidades necessárias para o desenvolvimento da disciplina de programação WEB.

Através da aplicação das atividades no laboratório de informática os alunos adquiriram competências de desenvolvimento pessoal, como por exemplo: conhecimento de suas capacidades pessoais e interpessoais, gestão do seu próprio tempo, originalidade, criatividade e capacidades de problematização.

\subsection{REALIZAÇÃO DO PROJETO}

Este item inicia-se listando as cinco etapas que compõem o projeto, em seguida é apresentado uma proposta de calendário para o projeto. Finalmente cada etapa do projeto é comentada.

Tabela 5.2 - Etapas do Projeto

\section{Etapas do Projeto}

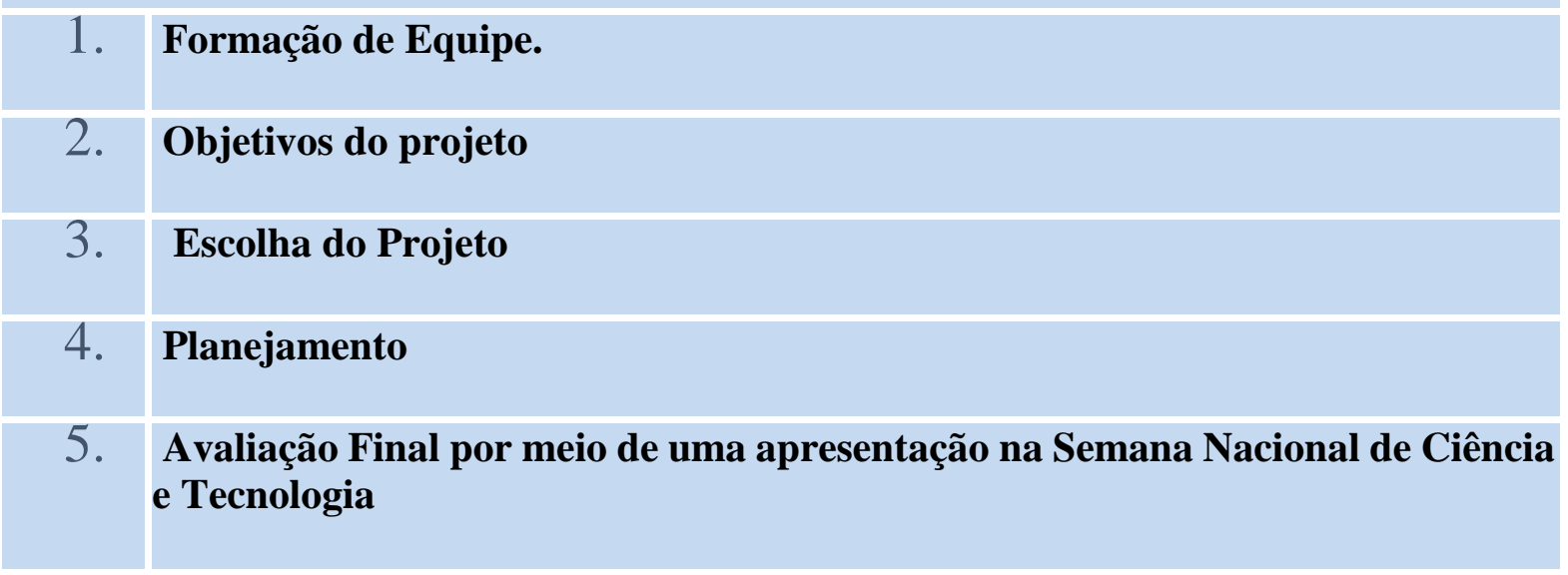


Tabela 5.3 - Calendário do projeto

\begin{tabular}{|l|l|l}
$\begin{array}{l}\text { Mês de Julho } \\
\text { De 1 a 25 - Introdução } \\
\text { De 26 a 27 - Como executar um projeto e elaboração } \\
\text { do Plano de ação }\end{array}$ & $\begin{array}{l}\text { Mês de Julho } \\
\text { De } 1 \text { a } 25 \text { - Desenvolvimento do Projeto } \\
26 \text { a } 27 \text { - Avaliação do Projeto }\end{array}$ \\
\hline $\begin{array}{l}\text { Mês de Setembro } \\
\text { De 1 a 25 Desenvolvimento do Projeto } \\
26 \text { a } 27 \text { - Avaliação do Projeto }\end{array}$ & $\begin{array}{l}\text { Mês de Outubro } \\
\text { De 1 a 9 - Desenvolvimento do Projeto } \\
\text { Dia 10 - Apresentação do Projeto (Semana Nacional } \\
\text { de Ciência e Tecnologia) }\end{array}$ \\
\hline
\end{tabular}

\section{Formação da equipe}

As equipes são formadas na sala de aula, os alunos conversam e se agrupam conforme suas áreas de interesse ou afinidades. Cada equipe se apresenta, fornecendo o nome do líder e de todos os integrantes. Figura 5.14 ilustra a formação de equipe.

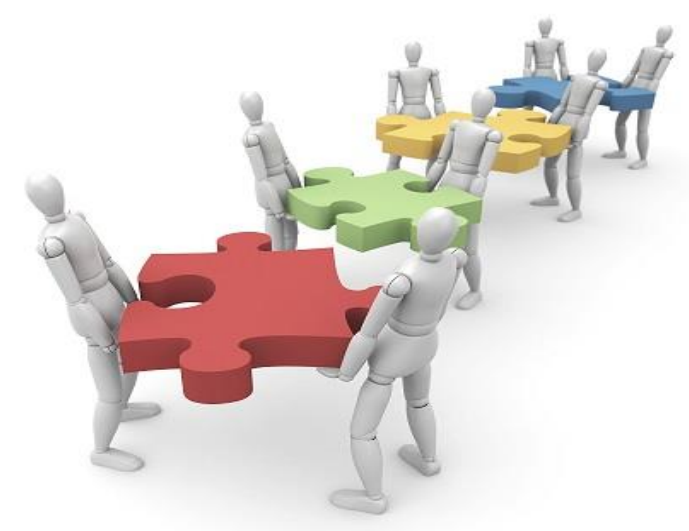

Figura 5.14 - Formação da equipe

\section{Objetivos do Projeto}

O projeto é um plano para a realização de um ato e também pode significar desígnio, intenção e esboço. Esta é uma palavra oriunda do termo em latim projectum que significa “ algo lançado à frente". 
Partindo desse conceito, é essencial que o aluno do curso Técnico em Informática, seja motivado em sua capacidade investigativa. A aplicação desses projetos no curso Técnico em Informática ganha, então, uma dimensão adicional que é contextualizar, em termos de objetivos educacionais.

O desenvolvimento de projetos é um processo interdisciplinar que exige conhecimentos, habilidades e competências de diversas áreas do conhecimento.

Para um melhor desenvolvimento do projeto foram estabelecidos alguns critérios descritos abaixo.

- O projeto deve envolver, de alguma forma, programação.

- O projeto deve ser realizado em grupo, incentivando os alunos, se conhecerem e trabalharem em equipe.

- O projeto não pode exigir conhecimentos avançados de programação e ou da plataforma Arduino.

- O projeto deve ser executado em quatro meses.

- Participação - Interesse e acompanhamento das aulas;

- Comprometimento - Pontualidade, respeito às normas disciplinares e de convivência, frequência e realização das atividades propostas.

- Deve ser feito um relatório técnico de todo projeto.

Os projetos são realizados em equipes sob a orientação do professor, e estão relacionados com uma das áreas de conhecimento do curso Técnico em Informática. No trabalho em equipe, os alunos têm a possibilidade de desenvolver habilidades técnicas e não técnicas.

Neste acordo é possível trabalhar as seguintes competências transversais:

Comunicação: A comunicação em equipe é essencial, para o sucesso das conquistas dos objetos.

Gerência de Projetos: Para gerenciar projetos é necessário elabora um plano, montar um cronograma, relatórios; definir objetivos; condução de reuniões e tomada de decisão.

Relacionamento Interpessoal: $\mathrm{O}$ relacionamento interpessoal ainda envolve a capacidade do ser humano de experimentar e discernir padrões, experimentar atrações do futuro e de sonhar e também de realizar potenciais.

Trabalho em equipe: É o resultado de um esforço conjunto e, portanto as vitórias e fracassos são responsabilidades de todos os membros envolvidos no projeto. Trabalhar em 
equipe significa criar um esforço coletivo para resolver um problema, são pessoas que se dedicam a realizar uma tarefa visando concluir determinado trabalho, cada um desempenhando uma função específica, mas todos unidos por um só objetivo, alcançar o tão almejado sucesso.

Esse enfoque permite que os alunos desde o início do curso tenham uma visão geral das diversas etapas de gestão de projetos e sua importância dentro do curso Técnico em Informática.

\section{Escolha do projeto}

A ideia dos projetos surgiu da necessidade de trabalhar um conteúdo teórico da disciplina de forma motivadora aos alunos no processo ensino-aprendizagem. Como início das atividades os alunos e orientadores se reuniram na sala de aula e se organizaram em duas equipes. Os temas escolhidos foram:

- Grupo 01 - Robô Sonoro com Arduino e carrinho controlado com Arduino.

- Grupo 02 - Automação Residencial com Arduino

Para iniciar os projetos os alunos receberam dos professores, em aulas presencias e encontros, um plano do projeto informado todas as atividades que deveriam ser desenvolvidas para a produção final dos projetos. Todos os encontros em grupo eram registrado pelo líder na ata do projeto.

A partir desse ponto todas as atividades foram realizadas no próprio espaço e tempo dos alunos sempre obedecendo ao cronograma previsto no plano de projeto. Cada líder criou um grupo no whatsapp para facilitar a interação entre todos os participantes da equipe.

Como se pode observar, há um maior acompanhamento do aprendizado do aluno por meio de várias atividades desenvolvidas no decorrer da disciplina, proporcionando ao aluno um aproveitamento maior do conteúdo e seu envolvimento no processo de construção da disciplina.

\section{Planejamento do Projeto}

O planejamento das atividades foi dividido em etapas, segue abaixo a tabela. 
Tabela 5.4 Planejamento das atividades

\begin{tabular}{|l|l|l|l|}
\hline \multicolumn{1}{|c|}{ ETAPAS } & \multicolumn{1}{|c|}{ DURAÇÃO } & PARTICIPA & ENTREGAS \\
\hline Pré-projeto & Duas semanas & Professores & Plano do projeto \\
\hline Projeto & Trimestre & Alunos/Professores & Projetos \\
\hline Pós-projeto & Encontro (4 horas) & Professores & Nota final \\
\hline
\end{tabular}

\section{PRIMEIRA ETAPA - PRÉ-PROJETO}

Essa etapa deve ser realizada em duas semanas precedente ao início do trimestre letivo, uma vez que ela consiste na elaboração do plano do projeto, o qual orienta os participantes, na experiência como um todo ao longo do trimestre.

\section{SEGUNDA ETAPA - PROJETO}

Essa etapa consiste na realização do projeto, ao longo do trimestre. De acordo com a figura 5.15 o projeto possui 5 (cinco) etapas, sendo que cada uma delas possui seus objetivos.

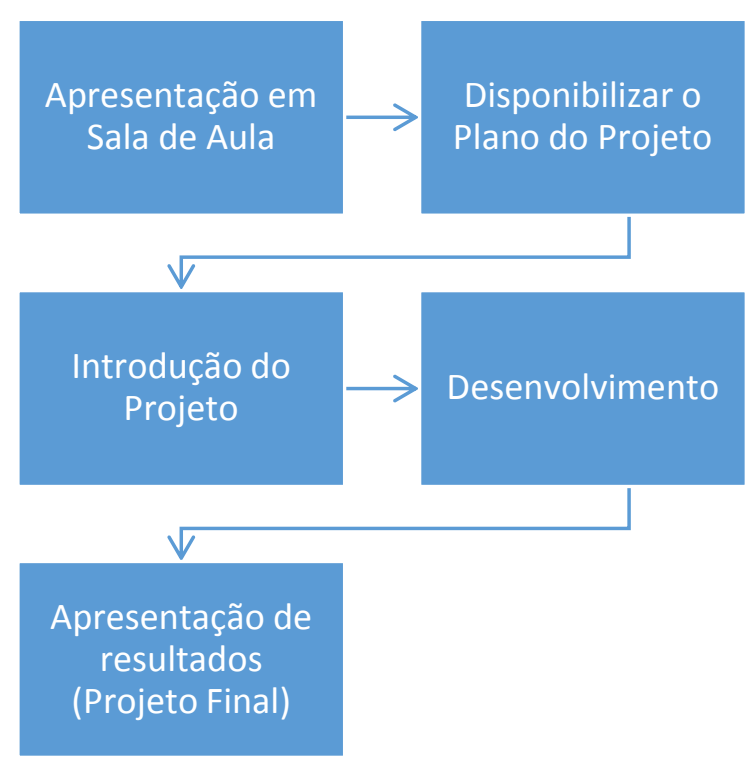

Figura 5.15 - Planejamento do Projeto

$\mathrm{Na}$ primeira aula do semestre, o professor apresenta a metodologia de trabalho aos alunos, explicando em detalhes o plano de aula. Segunda semana as equipes são definidas e divulgadas pelos professores. Os alunos são informados das regras e é divulgado o termo de comprometimento. 
Na terceira semana ofertou-se um mini-curso, com duração de 6 (seis) horas, para nivelar os conhecimentos relacionados a plataforma Arduino.

A tabela apresenta um resumo das atividades, eventos e atribuições relacionadas, às quatro semanas da fase de Apresentação:

Tabela 5.5 - Fase de apresentação

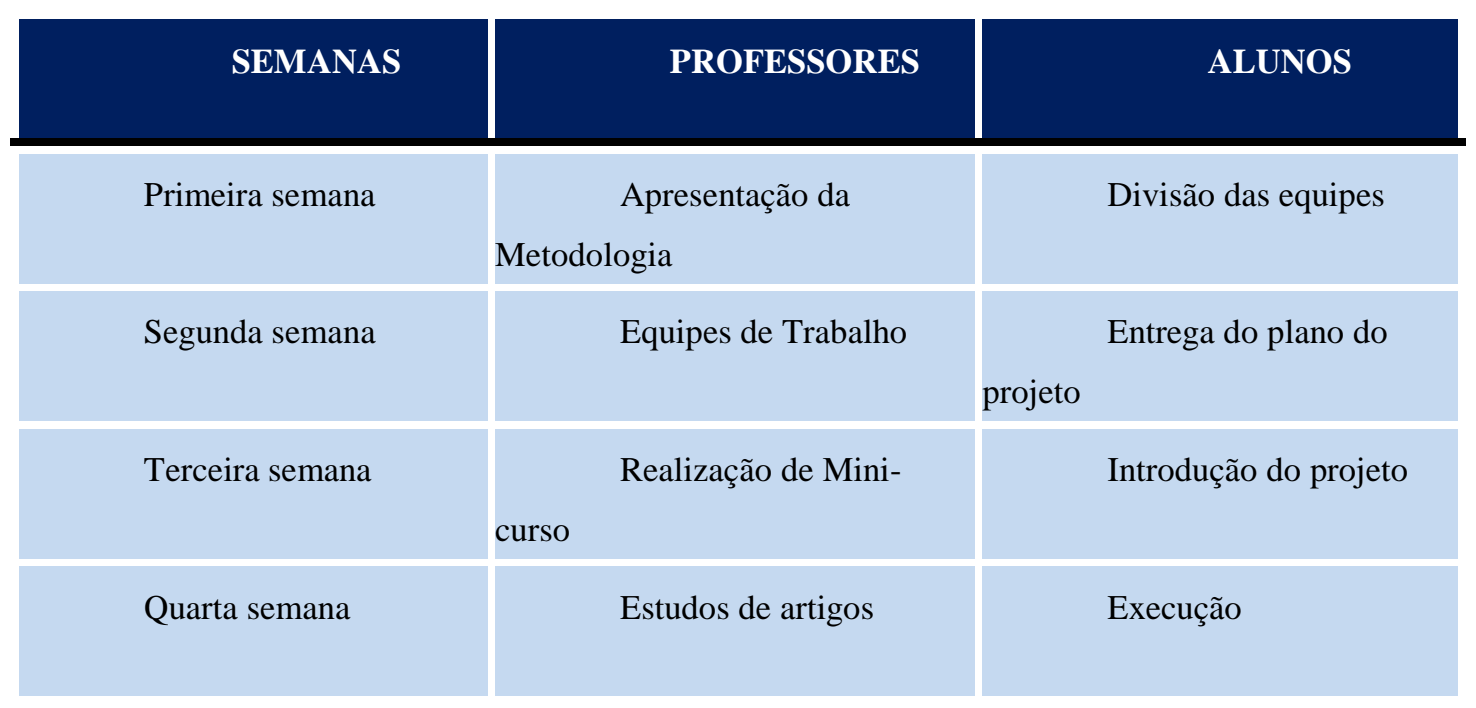

Na primeira fase as equipes são conhecidas, o plano do projeto entregue e o mini-curso realizado.

Na segunda fase as equipes elaboram o plano do projeto. No plano estabelece a definição, integração, preparação e coordenação das atividades a serem realizadas.

$\mathrm{Na}$ terceira fase aconteceu a execução do projeto. As equipes terminam o trabalho definido no plano a fim de cumprir os objetivos e entregas do projeto.

$\mathrm{Na}$ quarta fase as equipes, observam a execução do projeto, de forma que possíveis problemas possam ser identificados, e que as ações sejam tomadas, quando necessário.

$\mathrm{Na}$ quinta fase as equipes de trabalho, finalizam, formalmente, todas as atividades do projeto, verifica se as atividades definidas estão terminadas em todas as fases. 


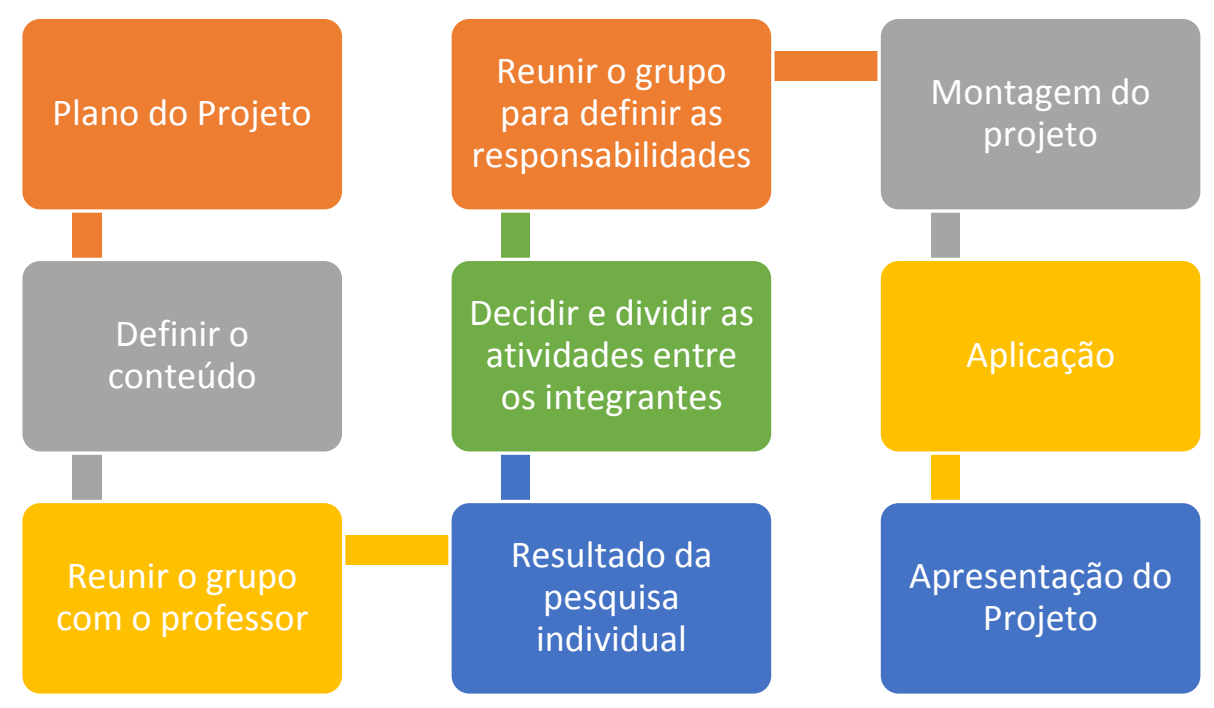

Figura 5.16 - Fases do Projeto

\subsection{APRESENTAÇÂO DOS PROJETOS NA SEMANA NACIONAL DE CIÊNCIA E TECNOLOGIA (SNCT) - IFNMG, CAMPUS ARINOS.}

Os resultados dos projetos desenvolvidos pelas equipes foram apresentados na Semana Nacional de Ciência e Tecnologia do IFNMG, Campus Arinos. As apresentações aconteceram no pátio e na sala de aula do Campus, cada grupo teve 50 minutos, sendo 15 minutos para perguntas.

\section{Equipe I - Robô Sonoro e Carrinho}

A equipe I apresentou dois projetos, inicialmente começaram com o projeto do Robô Sonoro, porém a equipe reuniu e juntos decidiram fazer mais um projeto, pois a programação do Robô Sonoro era simples, para dar mais ênfase fizeram um Carrinho controlado com a plataforma Arduino. Esses projetos pode ser observados nas figuras 5.18 e 5.19.

Os materiais utilizados no projeto do Robô Sonoro, foram:

- Sensor ultrassônico; 
- Arduino (Uno);

- Potenciômetro $10 \mathrm{~K}$ ohms;

- Protoboard;

- Jumpers para as conexões;

- Cabo USB para carregar o programa no Arduino.

A interação deste sensor com Arduino realizou as seguintes ações:

No setup foi definido dois pinos para utilizar como interface com o sensor. Um deles foi chamado de gatilho e foi definido como uma saída. O outro foi chamado de echo e foi definido como entrada.

No loop ficou, indefinidamente, medindo a distância entre o sensor e o obstáculo. A cada iteração foi feito o seguinte: instruiu o sensor a emitir um pulso ultrassônico colocando o pino gatilho em HIGH por alguns microssegundos e, depois, mediu-se a duração do pulso no pino echo.

Programação: 


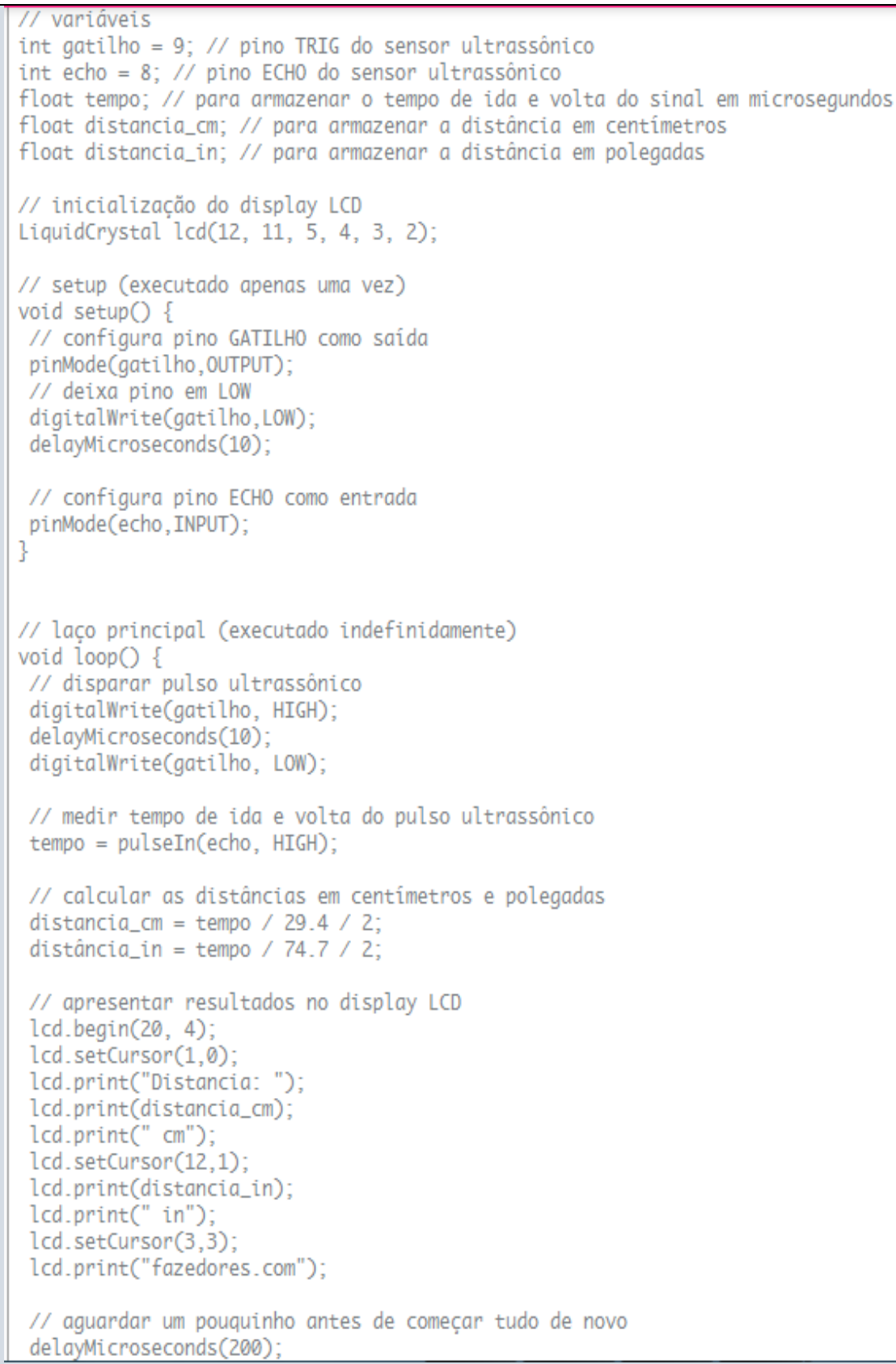

Figura 5.17 - código de robô sonoro 


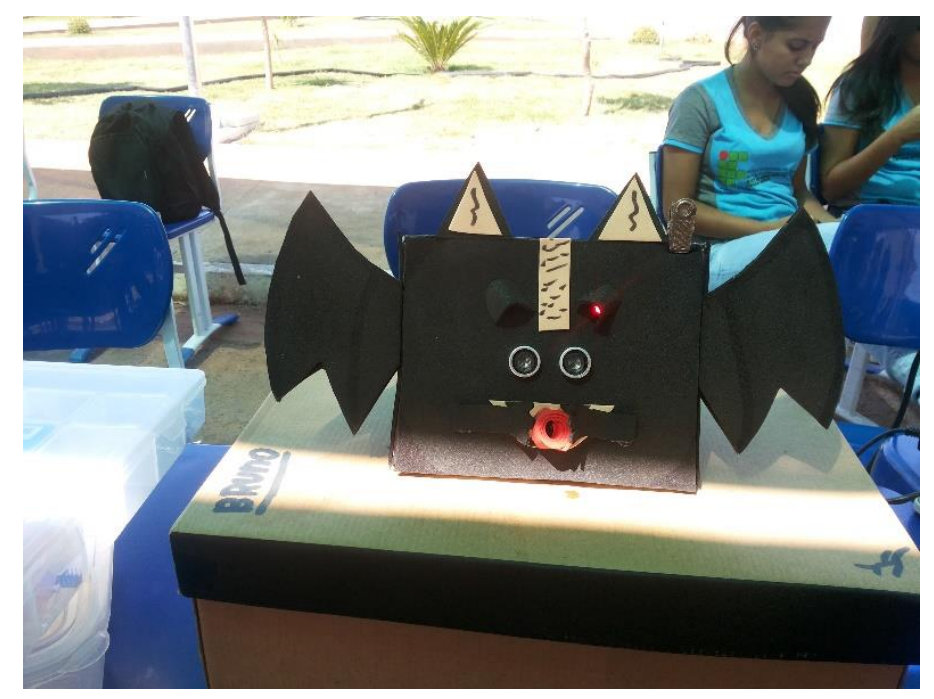

Figura 5.18 - Robô Sonoro

\section{Grupo I - Carrinho}

O programa inicia o bloco de setup definindo a velocidade em bounds para a comunicação entre o Arduino e o módulo Bluetooth. Em seguida ele envia um comando serial AT + NAME que modifica o nome do dispositivo Bluetooth. Em seguida é executado o comando de delay, ele é necessário porque o módulo leva um tempo para suas configurações. $\mathrm{O}$ bloco loop é onde a lógica principal do programa é implementado.

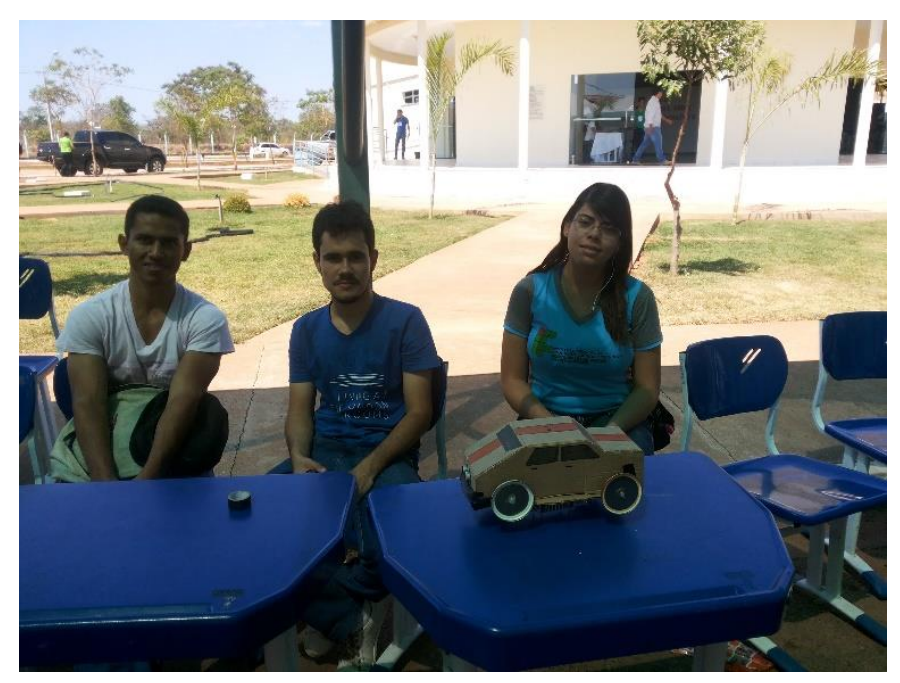

Figura 5.19 - Carrinho

\section{Programação:}




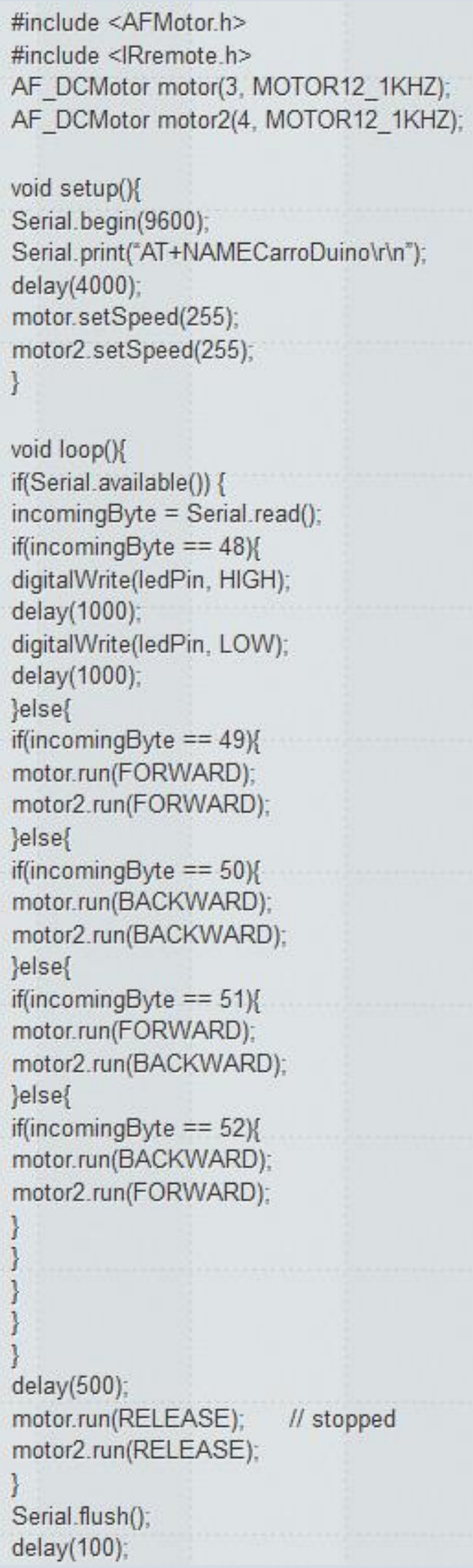

Figura 5.20 - Programação do carrinho 


\section{Equipe II - Automação Residencial com Arduino}

Nesse projeto os alunos fizeram uma automação residencial utilizando a plataforma Arduino. A automação residencial promove ao usuário interfaces descomplicadas e amigáveis, como também disponibiliza a possibilidade e informação de controle da residência a partir de qualquer lugar, através da internet.

Os materiais utilizados neste projeto foram:

Arduino;

Notbook e ou Smartphone ou IPhone;

Ethernet Shield;

LEDs;

Resistências;

Roteador.

Funcionamento:

Um programa instalado no notbook e celular Android que está conectado ao WiFi de uma casa, conecta-se um pequeno webserver que está rodando dentro do Arduino. O Arduino, por sua vez, está conectado a rede através do Shield Ethernet e possui um sketch que implementa um servidor web bem simples que receber comandos passados como parâmentros na URL da requisição. Cada comando liga ou desliga os LEDs que estão ligados às saídas do Arduino. Assim, ao acionar os botões no app que está rodando no celular, o app envia requisições para o webserver que roda no Arduino através da rede com parâmetros que indicam a ação a ser realizada. 


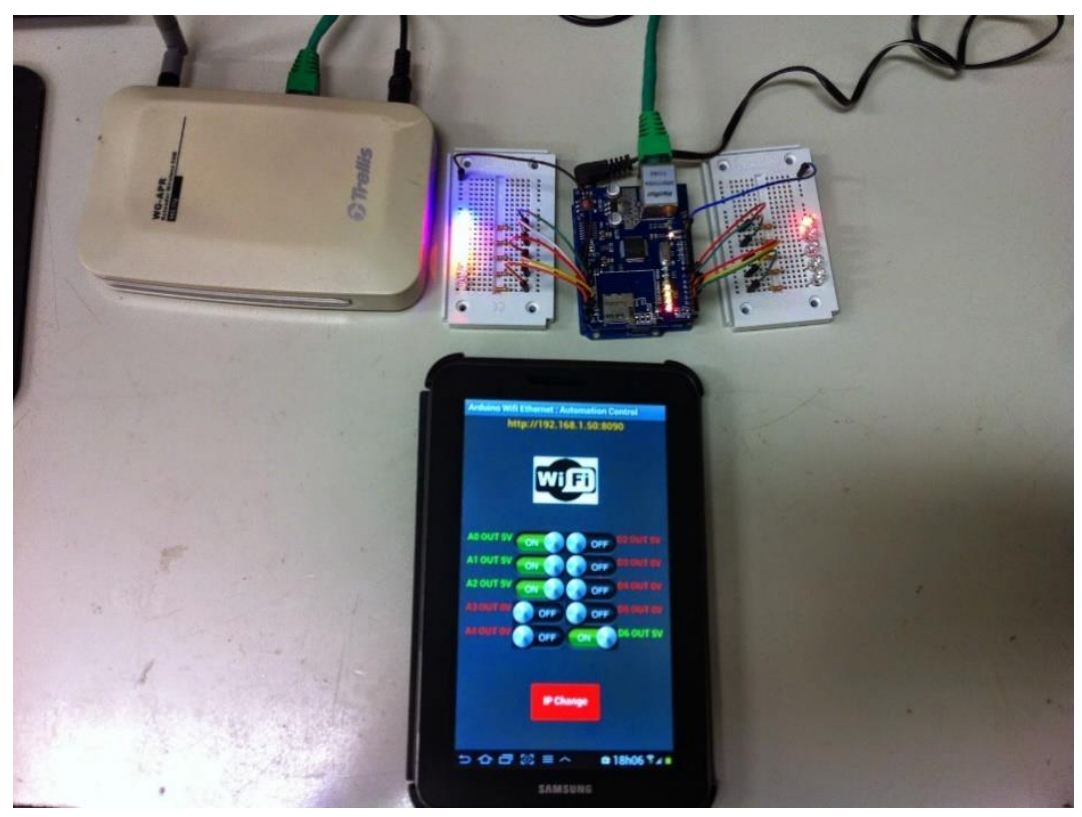

Figura 5.21 - Automação Residencial com Arduino

Na página inicial do sistema Web, aparece a tela de login, mostrada na figura 5.22, onde o usuário terá que digitar seu login e senha para acessar o sistema de sua residência.

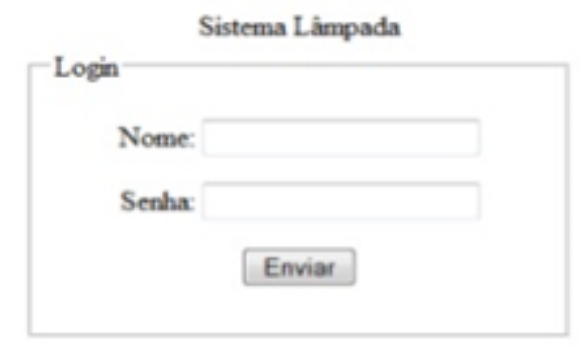

Figura 5.22 - Página do login utilizada no sistema

Ao clicar enviar o sistema realiza uma consulta no banco de dados, para confirmar se o login e senha são válidos. Se sim o sistema redireciona para a página principal do sistema.

Outra característica desse projeto, é que o mesmo pode ser utilizado em qualquer lugar e hora, basta ter acesso a internet.

Ao selecionar um dispositivo em algum cômodo ele já estará atualizado no banco de dados com o status de ligado ou desligado. 
Ao clicar sobre um determinado botão de um dispositivo, o mesmo envia um comando PHP, confirmando alguma ação realizada, seja de desligar ou de ligar uma lâmpada. Sabendo desses dados, é realizada o envio do comando para o Arduino atualizando o sistema.

Cada uma das lâmpadas pode receber como valor ON e OFF, representando ligado e desligado, de acordo com a figura 5.23.

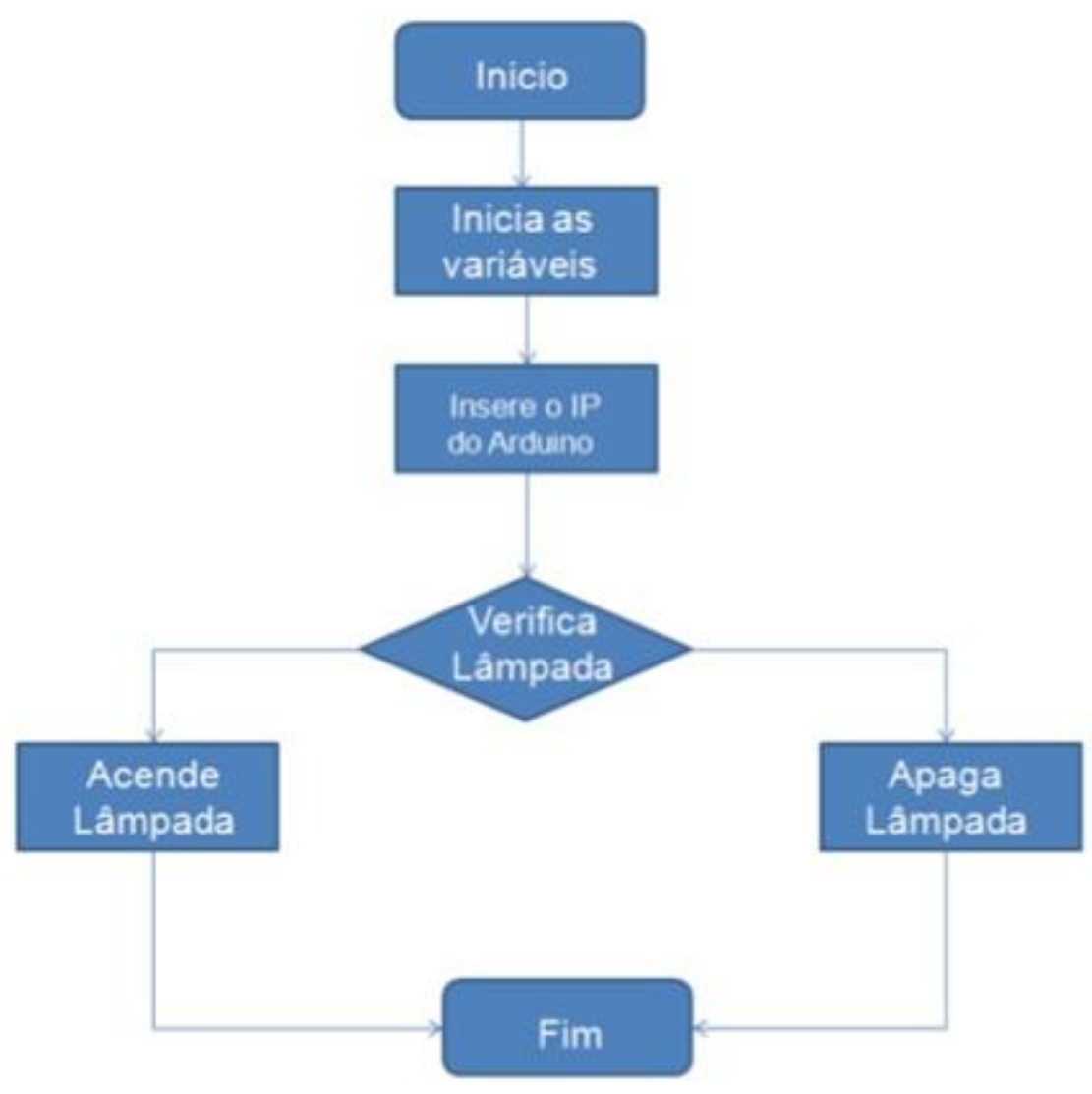

Figura 5.23 - Fluxograma de funcionamento Arduino

Abaixo temos exemplos das telas de comando para controle das lâmpadas da casa. Telas de comando para IPhone 


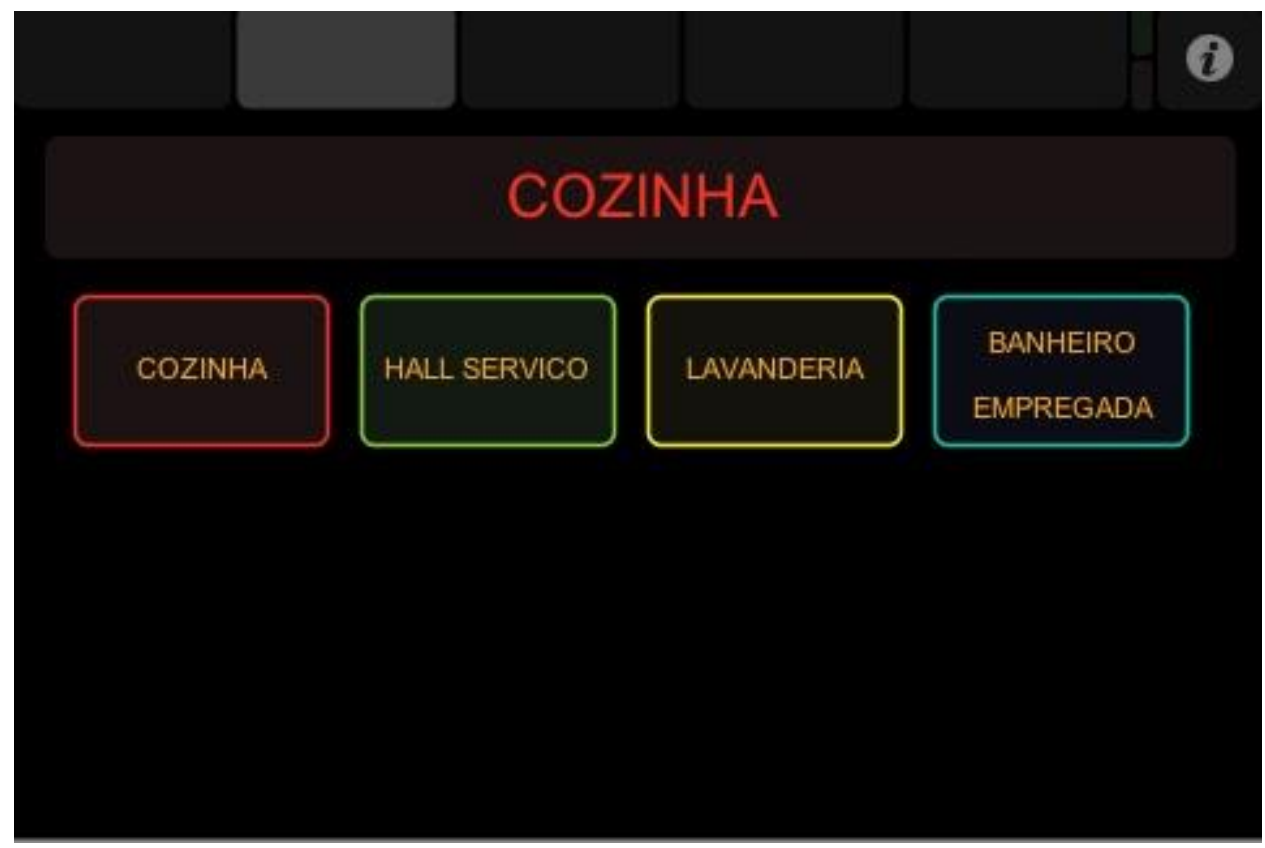

Figura 5.24 - Comando Cozinha

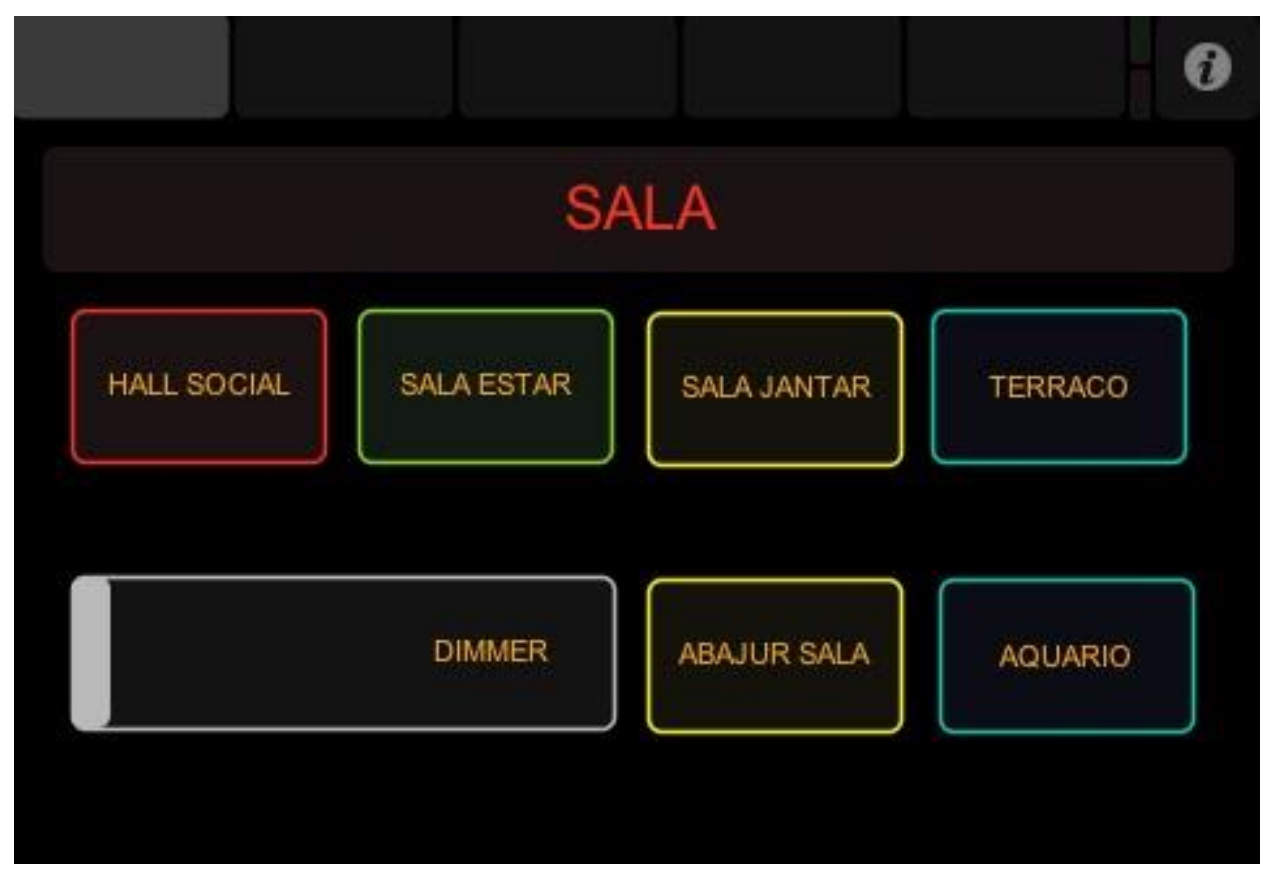

Figura 5.25 - Comando Sala 


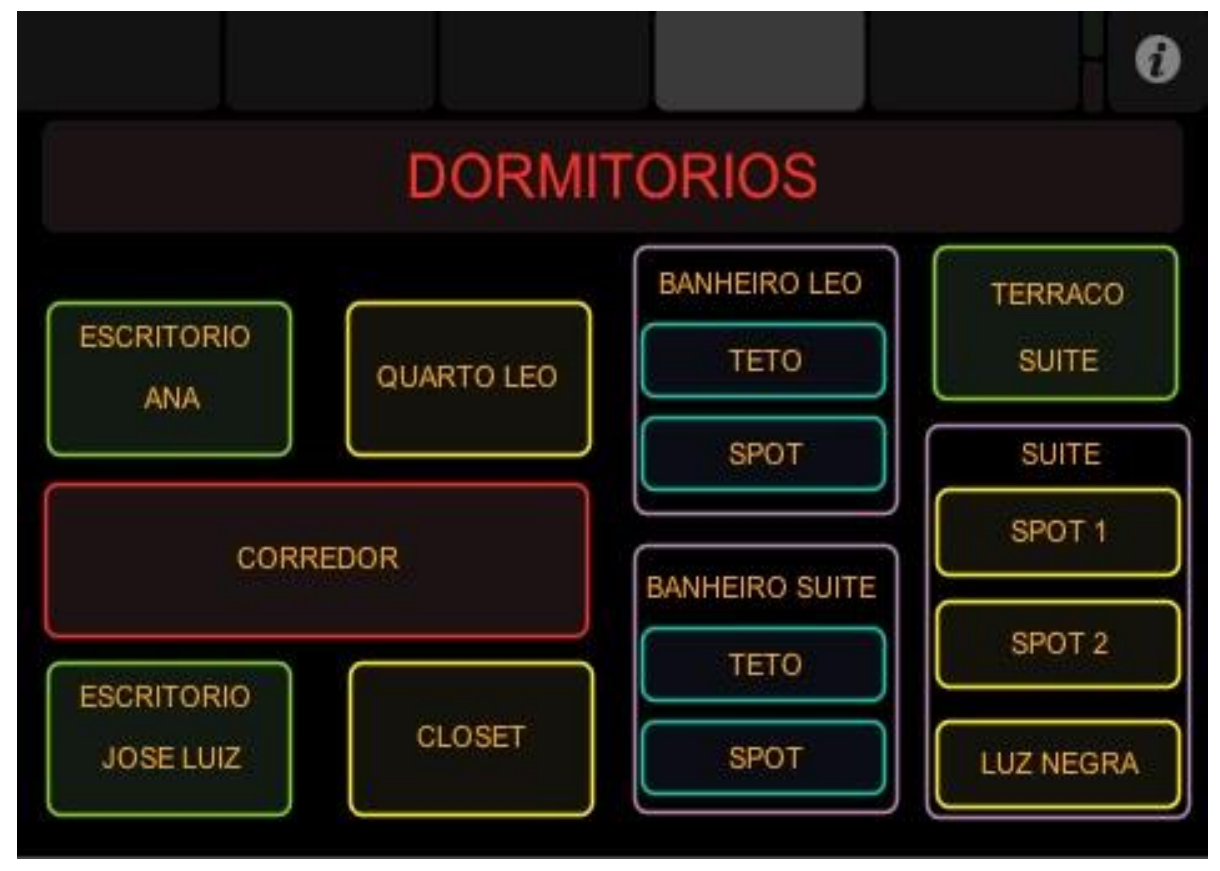

Figura 5.26 - Comando Dormitórios

A equipe II apresentou seu projeto na Semana Nacional de Ciência e Tecnologia (SNCT) do IFNMG, Campus Arinos, figuras 5.27, 5.28 e 5.29.

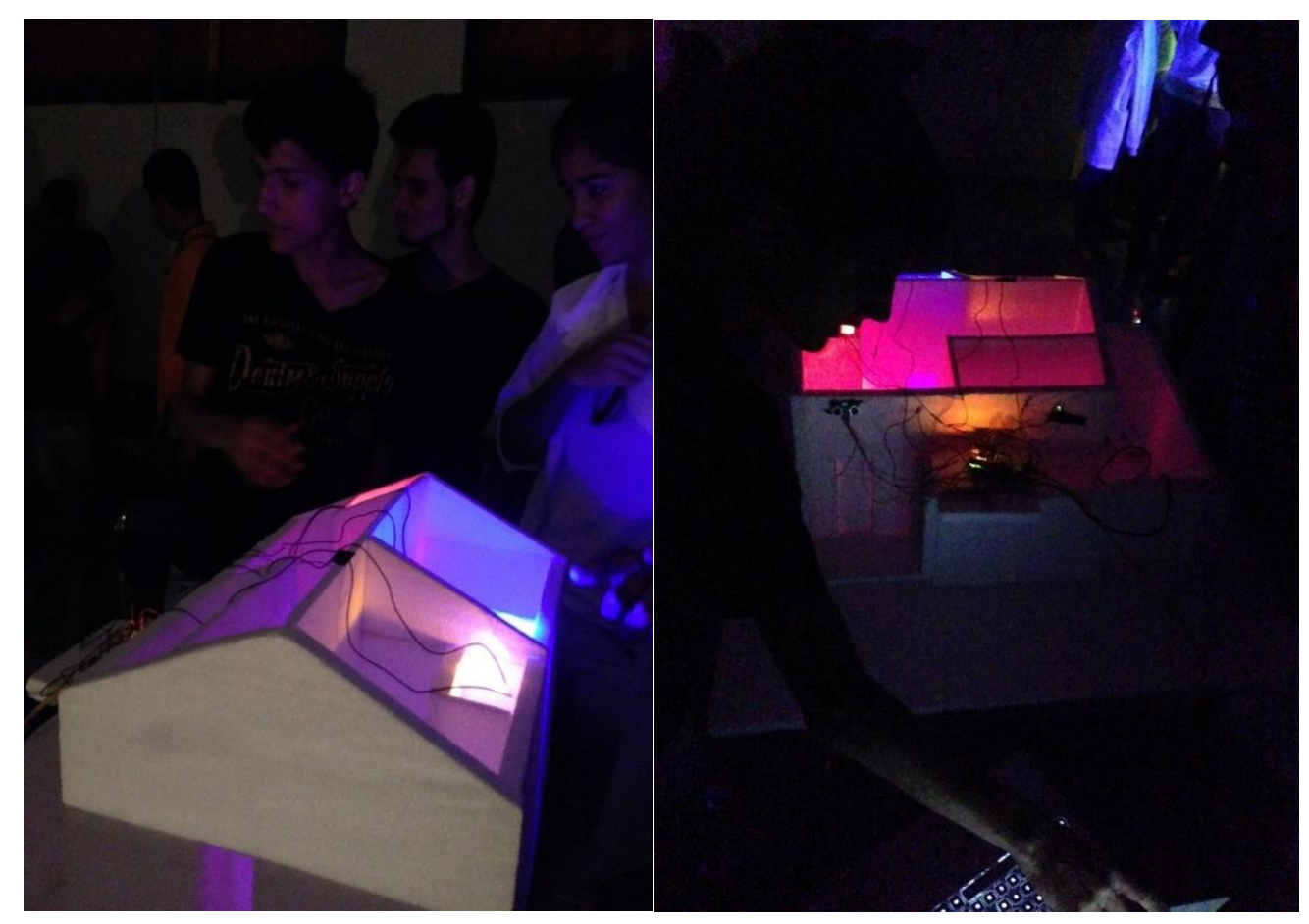

Figura 5.27 - Apresentação do projeto II na SNCT 


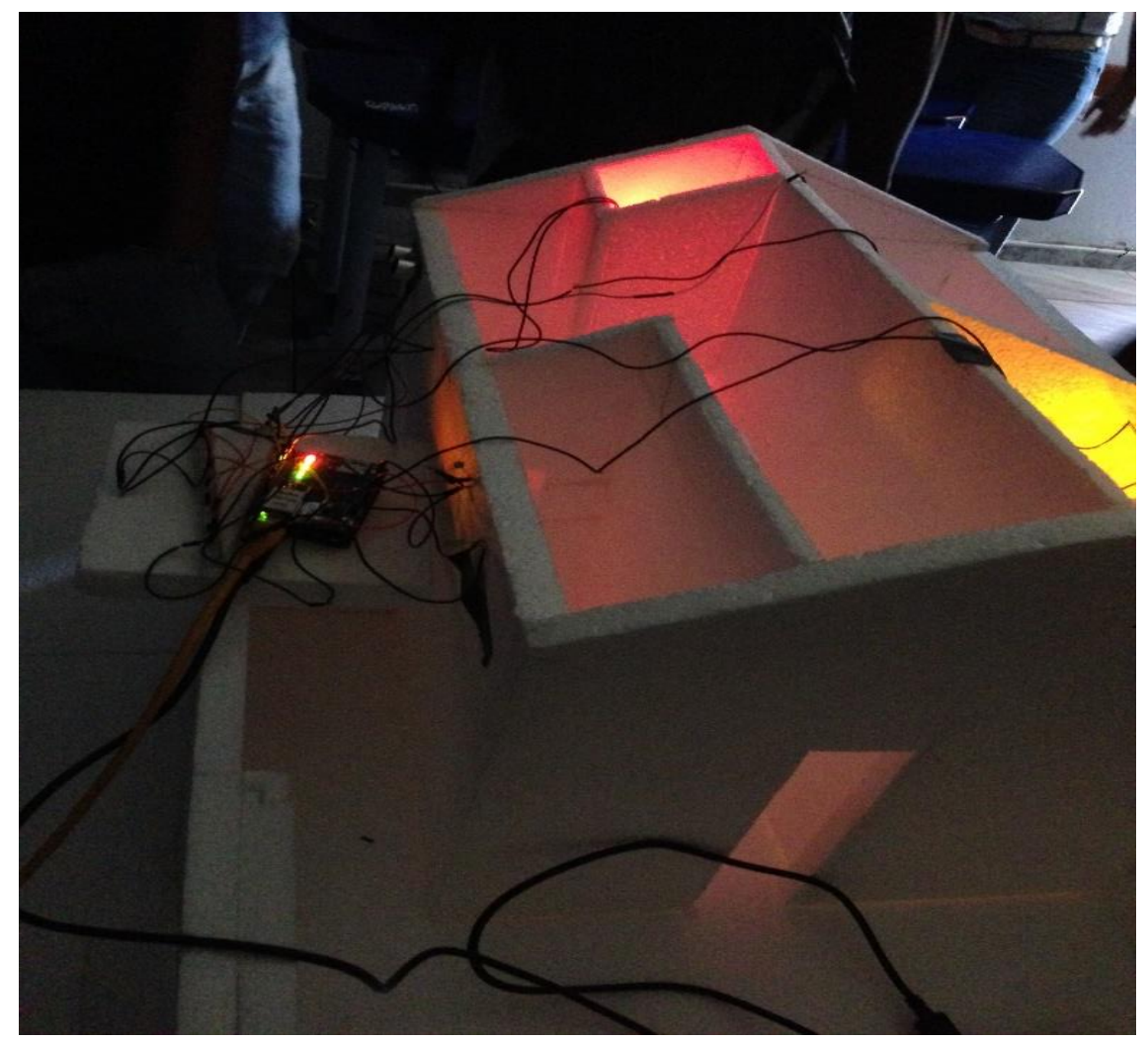

Figura 5.28 - Projeto Residencial com Arduino

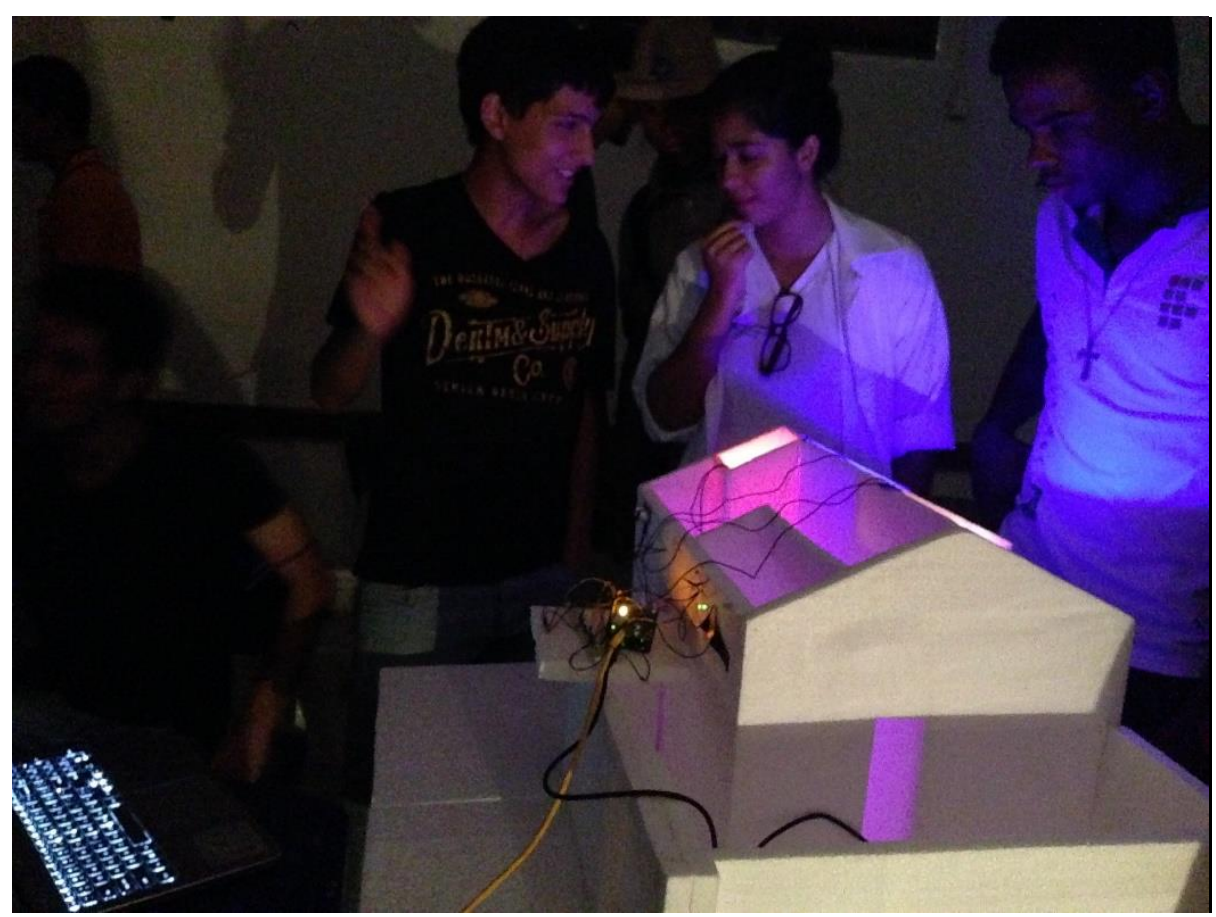

Figura 5.29 - Projeto Automação Residencial com Arduino 
Por meio das apresentações na feira tecnológica, os alunos perderam o medo de falar em público, desenvolvendo assim competências de desenvolvimento interpessoal, capacidade de liderança, desenvolvimento de atividades colaborativas, além do interesse de buscar novos conhecimentos.

\subsection{AVALIAÇÃO DO DESEMPENHO DOS ALUNOS NA DISCIPLINA}

As avaliações propostas serviram como importante instrumento para a verificação desta mudança, o que foi imprescindível conhecer para que houvesse uma aproximação maior do estudante com a área, seu envolvimento com projetos, e ainda as competências possivelmente que pudessem ser desenvolvidas em relação à liderança, trabalho em equipe e comunicação.

As formas de avaliação foram diversificadas sendo utilizados vários instrumentos avaliativos, tornando possível detectar as dificuldades encontradas pelos alunos no processo de ensino e aprendizagem logo nas primeiras atividades.

Com critérios gerais para aprovação na disciplina foram avaliadas as seguintes atividades durante o processo de desenvolvimento da disciplina:

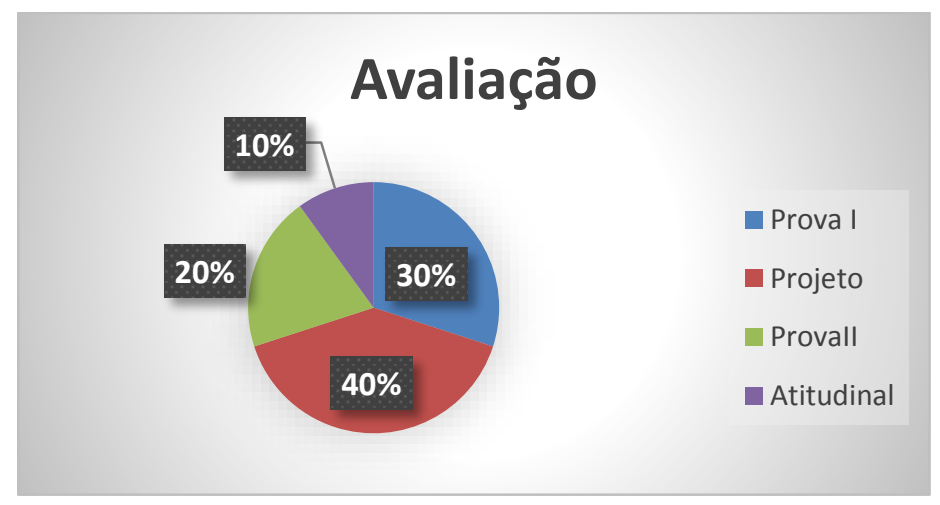

Figura 5.30 - Avaliação da disciplina

Os alunos tiveram duas avaliações presencial uma teórica no valor de $30 \%$ da nota final e uma prática no valor de $20 \%$ da nota final. O projeto utilizando a plataforma Arduino foi avaliado em $40 \%$ da nota final. 
Essas avaliações oportunizaram competências de aprendizagem dos alunos, através de aulas desenvolvidas em laboratório de informática, além de saber desenvolver excelentes projetos.

\section{RESULTADOS OBTIDOS NA IMPLANTAÇÃO DA PLATAFORMA ARDUÍNO APLICADO A DISCIPLINA WEB II}

Neste item apresentamos os resultados alcançados na aplicação da Plataforma Arduino na disciplina de programação WEB. Esta foi observada de forma qualitativa, a partir do desempenho da experiência. A partir das avaliações de aprendizagem realizadas no decorrer da disciplina, foi possível verificar como se deu o desenvolvimento técnico e não técnico, resultados da experiência no uso da Plataforma Arduino, bem como, avaliar o grau de envolvimento e a percepção dos alunos.

\subsection{AVALIAÇÃO DA APRENDIZAGEM}

O Curso Técnico em Informática, tendo sua estrutura curricular baseado em competências, habilidades e bases tecnológicas, tem seu processo de avaliação baseado no desenvolvimento dessas potencialidades.

A avaliação foi ampla, contínua, gradual, cumulativa e cooperativa, envolvendo todos os aspectos qualitativos e quantitativos da formação do educando.

Os instrumentos de avaliação contemplaram avaliação escrita contendo questões abertas e fechadas; avaliação oral, atividades desenvolvidas nas aulas práticas, observando o interesse do aluno, trabalhos de pesquisa, projetos com a plataforma Arduino e exercícios, a fim de atender às peculiaridades dos alunos e de oportunizar uma avaliação adequada aos diferentes objetivos. Portanto, avaliou na disciplina de WEB II se o aluno desenvolveu as competências e habilidades propostas, se ele foi capaz de utilizar, mobilizar os conteúdos de estudo para resolver situações práticas, da vida diária, da profissão que poderá conquistar. Avaliou-se também alguns aspectos atitudinais mais específicos como:

- Participação - Interesse e acompanhamento das aulas;

- Comprometimento - Pontualidade, respeito às normas disciplinares e de convivência, frequência e realização das atividades propostas. 
Nesta perspectiva, a avaliação foi formativa, ou seja, um trabalho contínuo de regulação da ação pedagógica. Os aspectos qualitativos foram prioritários perante os quantitativos. A função da avaliação é permitir ao professor identificar os progressos e as dificuldades dos alunos para dar continuidade ao processo, fazendo as mediações necessárias para que as aprendizagens aconteçam.

A avaliação formativa é destacada como um processo contínuo, onde o ponto de partida é o critério de transformar a avaliação em um instrumento que evolui e pode ser melhorado com o tempo a saber aprender a aprender.

A avaliação formativa tem a finalidade de proporcionar informações acerca do desenvolvimento do processo de ensino e aprendizagem, para que o professor possa ajustá-lo às características dos estudantes a que se dirige. Suas funções são as de orientar, apoiar, reforçar e corrigir. [34]

A avaliação, como processo educacional, permite delinear, obter e fornecer informações úteis para a tomada de decisões com vistas a atingir níveis mais aprimorados de realizações. A avaliação de aprendizagem dos alunos se fundamentará não simplesmente na ação de julgar a reprodução dos conteúdos aprendidos, mas no nível de interatividade com o objeto de estudo, no processo de construção de conceitos e na aplicabilidade destes conhecimentos na resolução de problemas, bem como na resposta observada após experimentação e prática.

A avaliação de aprendizagem foi realizada por meio de diversos instrumentos: Elaboração de projetos, estudo de casos, exames parciais e globais, exercícios, participação em sala, relatórios de atividades, seminários, trabalhos, individuais e grupais.

Priorizou-se instrumentos de avaliação estimuladores da autonomia na aprendizagem, que envolveu atividades realizadas individualmente e em grupo e forneceu indicadores da aplicação, no contexto profissional dos conhecimentos adquiridos, visando contemplar as peculiaridades dos alunos.

O processo de avaliação permitiu evidenciar até que ponto o aluno pôde absorver o conhecimento e avançar em habilidades no decorrer do curso.

\subsection{2 - DIAGNÓSTICO DO DESEMPENHO DA EXPERIÊNCIA}

\subsubsection{Aula Teórica e Prática}


As aulas teóricas foram propostas com um objetivo de desenvolver habilidades técnicas e não técnicas da disciplina. Percebeu-se que, através dos resultados, que as aulas teóricas ajudou os alunos na participação e colaboração em grupo. De acordo com as respostas dos questionários foi feito uma análise de forma qualitativa. No questionário o aluno avaliou de um (1) até quatro (4), onde 1 o aluno discordava fortemente, 2 discordava, 3 concordava e 4 concordava fortemente. Na enquete realizada verificou-se que a maioria dos alunos aprovou as aulas teóricas, figura 6.1 .

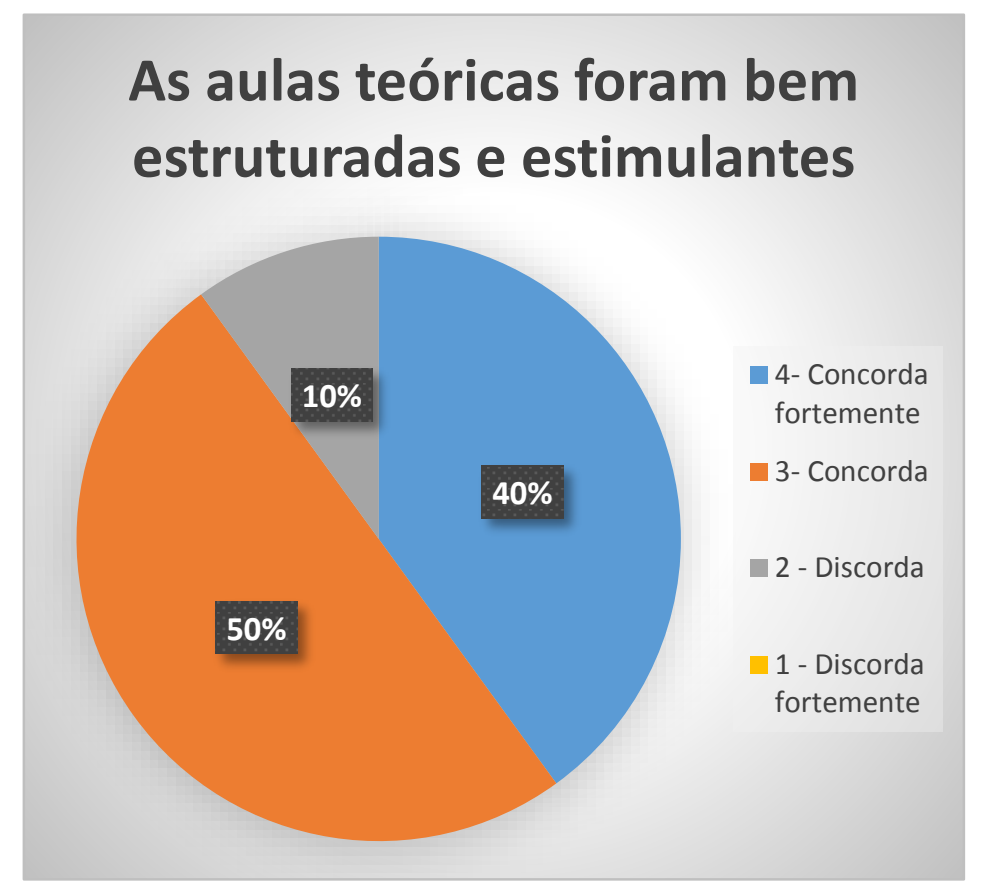

Figura 6.1 - Aulas teóricas

Observou-se através dos resultados demonstrados que $90 \%$ dos alunos concordam com a forma como as aulas presenciais foram conduzidas, fato que se deve a forma de ensinar com participação dos alunos. Ressalta-se que os $10 \%$ dos resultados negativos são correspondentes a 2 alunos de uma turma de 20 alunos.

Outras competências foram estimuladas durante as aulas presenciais, como por exemplo, o seminário. Nesta atividade esperava-se que o aluno desenvolvesse competências de liderança, trabalho em equipe por meio das atividades colaborativas. Comumente um seminário é desenvolvido de forma que o aluno tenha que pesquisar sobre um assunto, a fim de, possibilitar a reflexão e a discussão na hora da apresentação.

As aulas práticas aconteceram no laboratório de Informática, foi trabalhado os tópicos da disciplina com a implementação da platoforma Arduino. Primeiramente os alunos 
conheceram a plataforma, onde foram apresentados as funções, bibliotecas, características e funcionalidades. Figura 6.2.

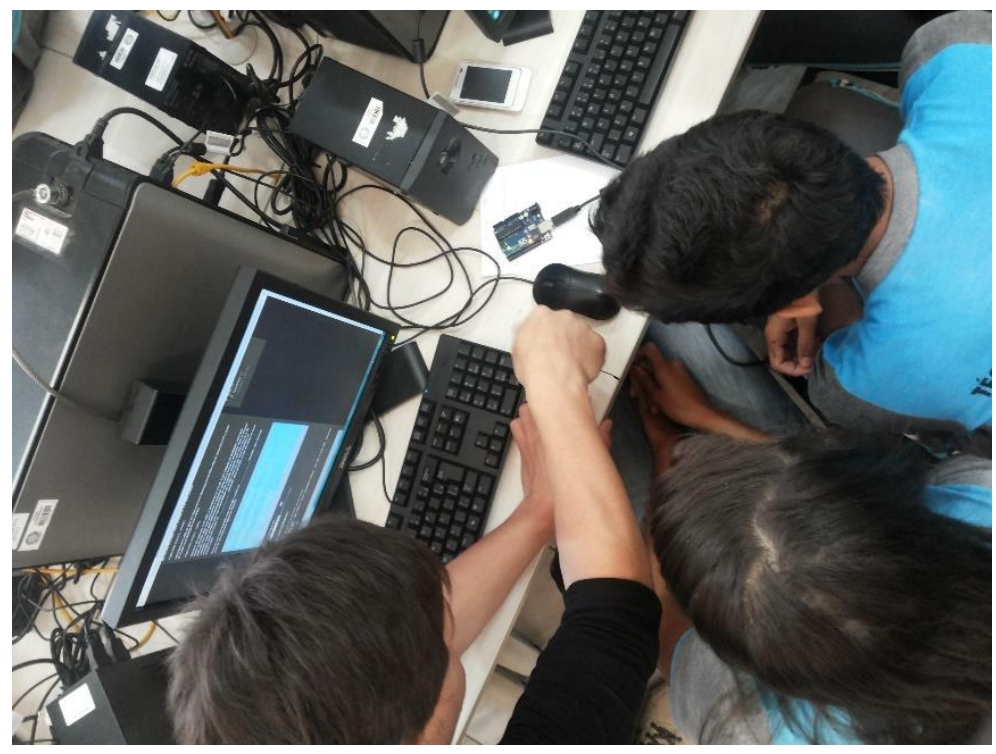

Figura 6.2 - Aula prática com Arduino no Laboratório de Informática

Com as atividades no laboratório de informática os alunos adquiriram competências transversais, conhecendo suas capacidades pessoas e interpessoais, revelando capacidades de problematização, criatividade, originalidade, interação e participação em grupo.

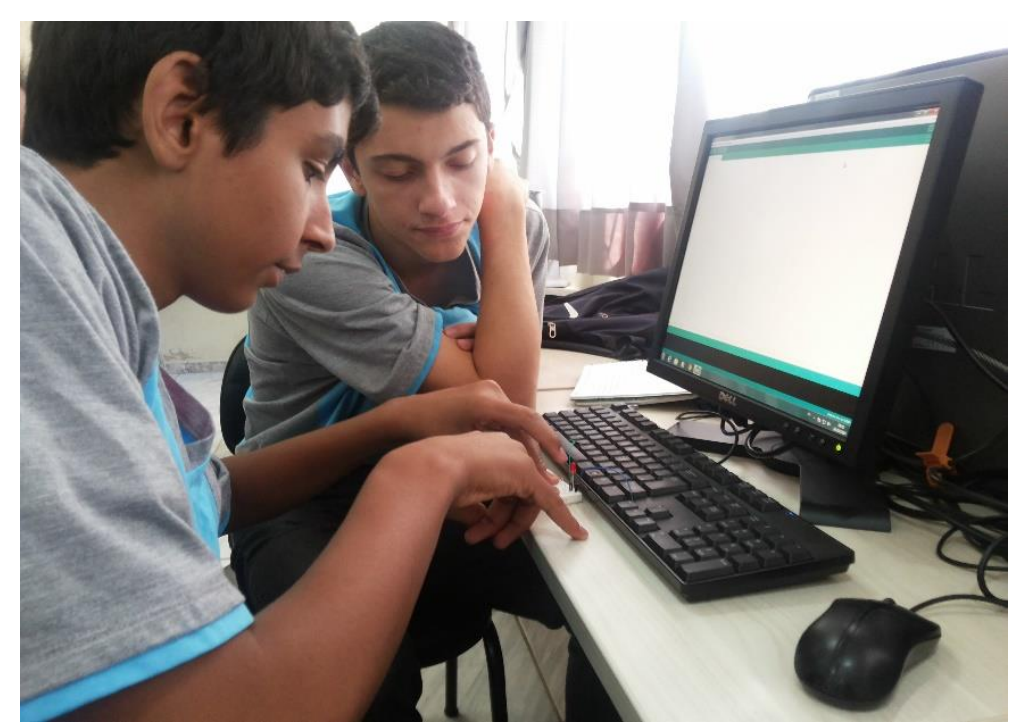

Figura 6.3 Aula prática no Laboratório de Informática 


\subsubsection{A Disciplina WEB II}

A disciplina teve característica proporcionar ao aluno competências transversais e técnicas. Na enquete realizada verificou-se que a maioria dos alunos acharam a disciplina relevante para o seu aprendizado, figura 6.4

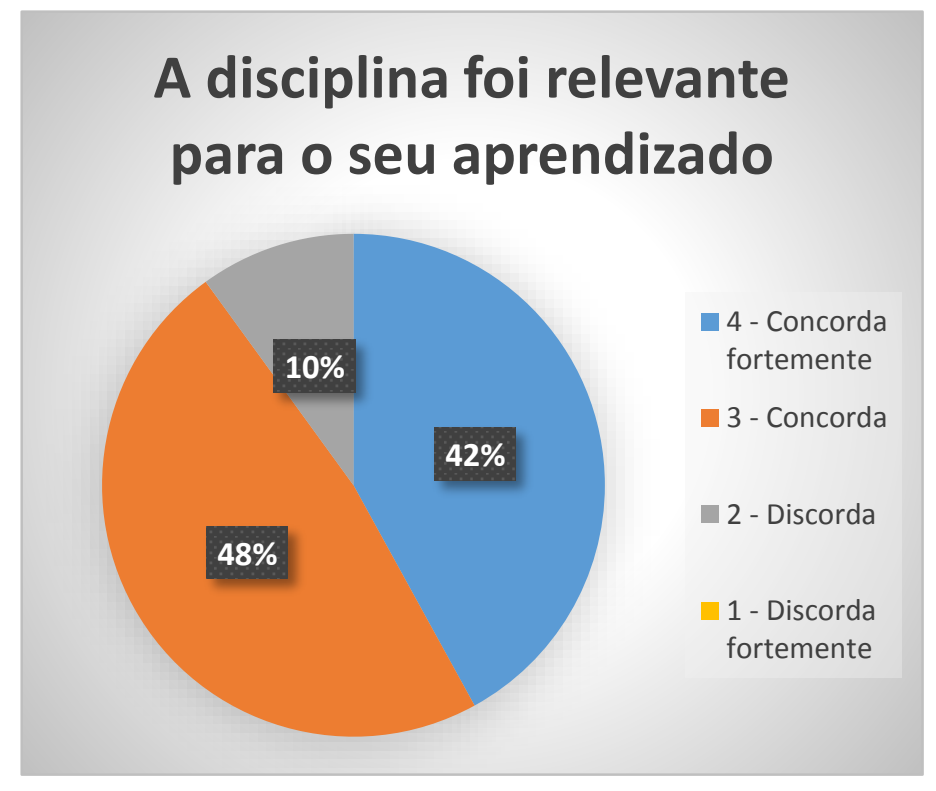

Figura 6.4: Aprendizado do aluno

De fato, é possível afirmar, com base nos dados, que esta experiência com a plataforma Arduino conseguiu, mediante o processo de soluções de problemas e o trabalho em equipe, estimular o desenvolvimento com os atributos listados em pesquisas sobre perfis desejáveis do Técnico em Informática.

Sobretudo, a aplicação da plataforma Arduino proporcionou aprendizagens aplicáveis no presente no que concerne tanto hábitos de estudo mais adequados quanto a estratégias profissionais mais eficazes, como relatou o aluno Handeres:

A experiência foi boa porque colocou a nossa equipe em situações que podemos enfrentar na nossa vida profissional. Eu tinha a tendência de resolver as coisas rapidamente, hoje penso muito mais, penso nas pessoas, nos problemas e na forma de argumentação.

Essa concordância com a pesquisa sobre aplicação da plataforma Arduino se estende às desvantagens levantadas pelos alunos neste trabalho destaca-se a questão do tempo, pois aumentou a carga de trabalho dos alunos. 
É importante considerar este efeito porque o tempo insuficiente pode estar, por exemplo, na origem da queda de motivação dos alunos observada ao final do curso.

O comprometimento dos alunos, por sua vez, só pode concretizar-se mediante a disponibilidade de tempo para o estudo independente. Por outro lado, a questão do tempo está vinculada ao bom uso que se faz dele. A eficácia no uso do tempo está intimamente ligada a hábitos de estudo adquiridos em ambientes educacionais convencionais.

Em relação ao trabalho em equipe deduziu-se a percepção dos alunos sobre os seguintes aspectos: Dificuldade no projeto, participação, liderança e capacidade de relacionar em equipe, figura 6.5 .

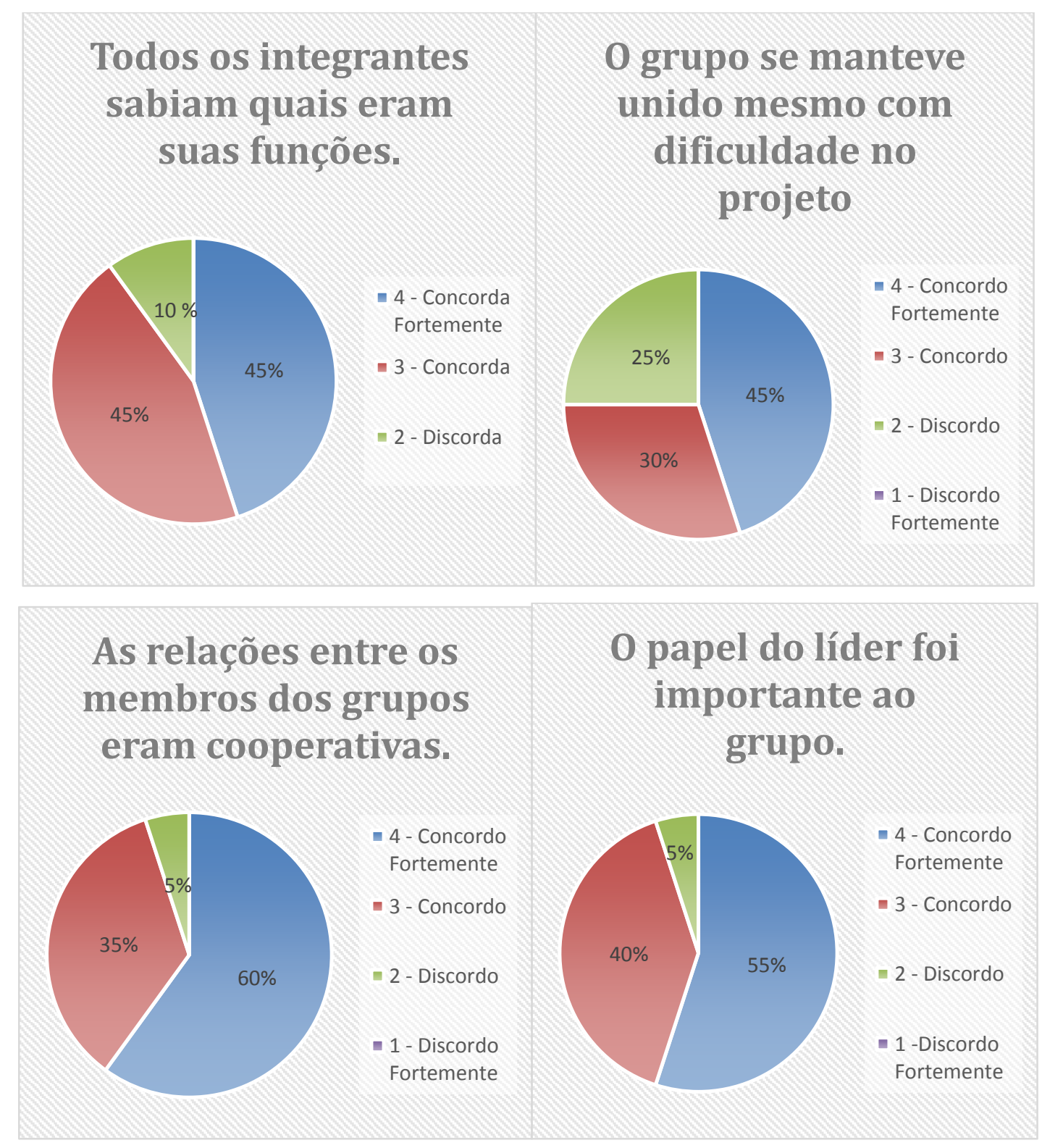




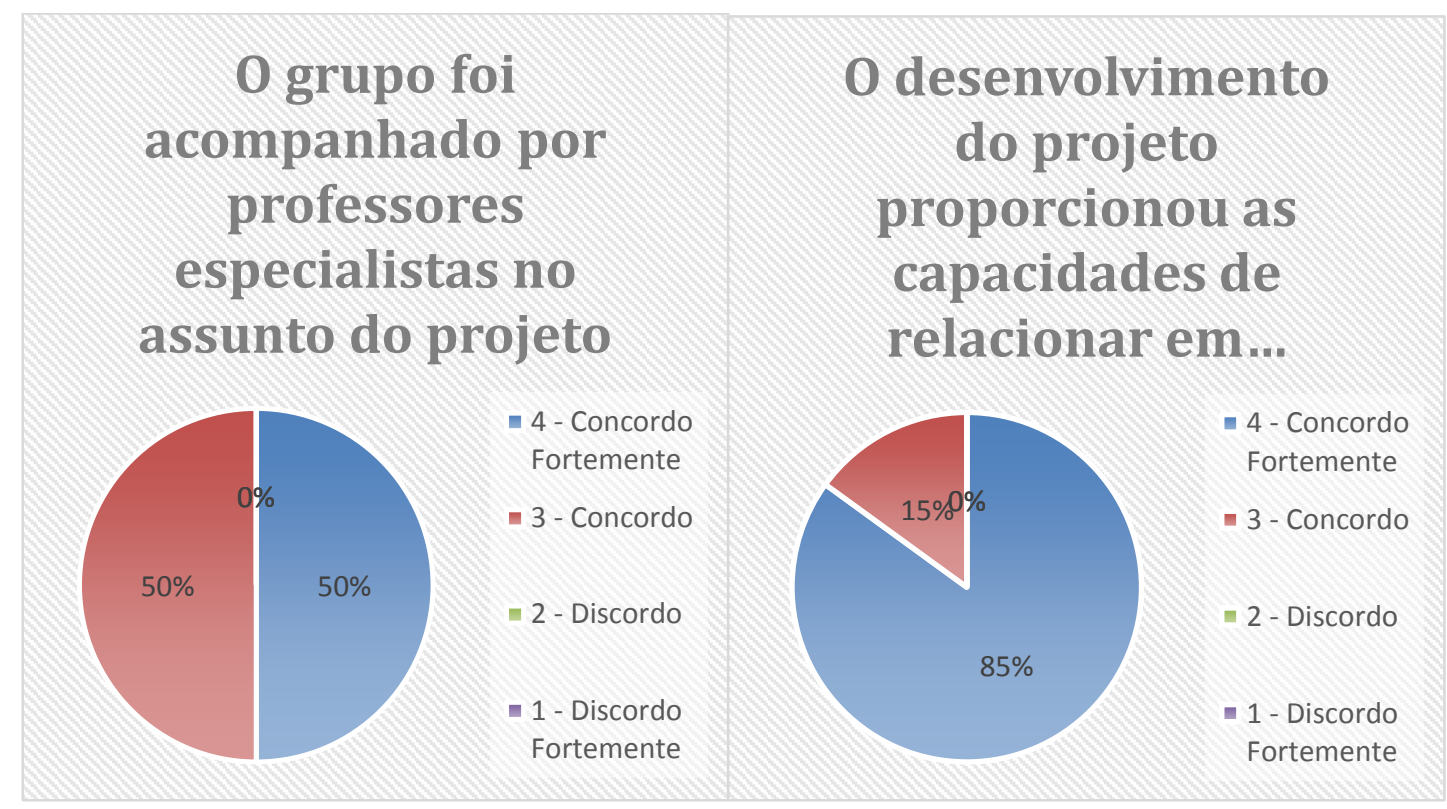

Figura 6.5 - Aspectos: funções, dificuldade no projeto, participação, liderança, acompanhamento de especialistas e trabalho em equipe.

Um projeto colaborativo desenvolve habilidades técnicas e não técnicas, analisando os gráficos, conclui-se que é preciso estimular mais os alunos para o trabalho em equipe, pois ainda há dificuldade no relacionamento entre os membros do grupo e no papel do líder.

De acordo com os alunos a plataforma Arduino foi de grande relevância na disciplina de WEB II, pois através dessa ferramenta eles sentiram mais motivados e puderam vivenciar uma prática que contribui diretamente na aprendizagem. Na enquete realizada verificou-se que a maioria dos alunos concordam que com aplicação da Plataforma Arduino os alunos ficaram mais motivados e obteve sucesso na disciplina de Programação WEB II, figura 6.6. 


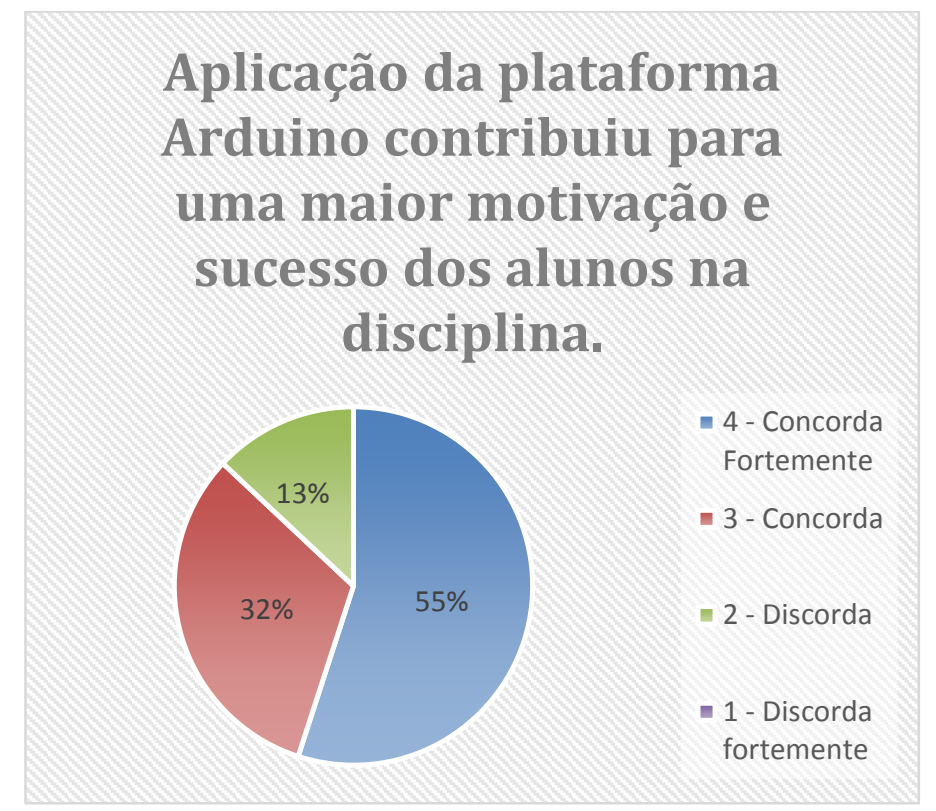

Figura 6.6: Aplicação da plataforma Arduino

Através da aplicação da Plataforma Arduino, os alunos puderam desenvolver competências interpessoal, exercendo sua capacidade de liderança entre o grupo, desenvolveram atividades colaborativas, além de que estimulando seu interesse em buscar novos conhecimentos, através de pesquisas relacionados a plataforma Arduino.

No aspecto da interação, a plataforma Arduino contribui de forma significativa, o que pode ser explicado pelo desempenho dos alunos no processo de aprendizagem, com isso, aumentou a interação e o desenvolvimento do trabalho coletivo.

\subsubsection{Atividades Virtuais (assíncrona)}

As atividades assíncronas propiciaram aos alunos o senso de assiduidade, autonomia, liderança, responsabilidade e pontualidade. Além dessas competências não técnicas aconteceu o desenvolvimento de habilidades técnicas, onde foi necessário a utilização de ferramentas tecnológicas (Moodle, Google Docs e WhatsApp) no desenvolvimento das atividades.

Observou-se que, através do AVA - Moodle, os alunos tiveram mais tempo no desenvolvimento e gerenciamento dos exercícios, além de adquirir autonomia e responsabilidade na resolução dos exercícios e problemas. 
Na enquete realizada verificou-se que a utilização do AVA contribui para o processo de ensino aprendizagem, figura 6.7.

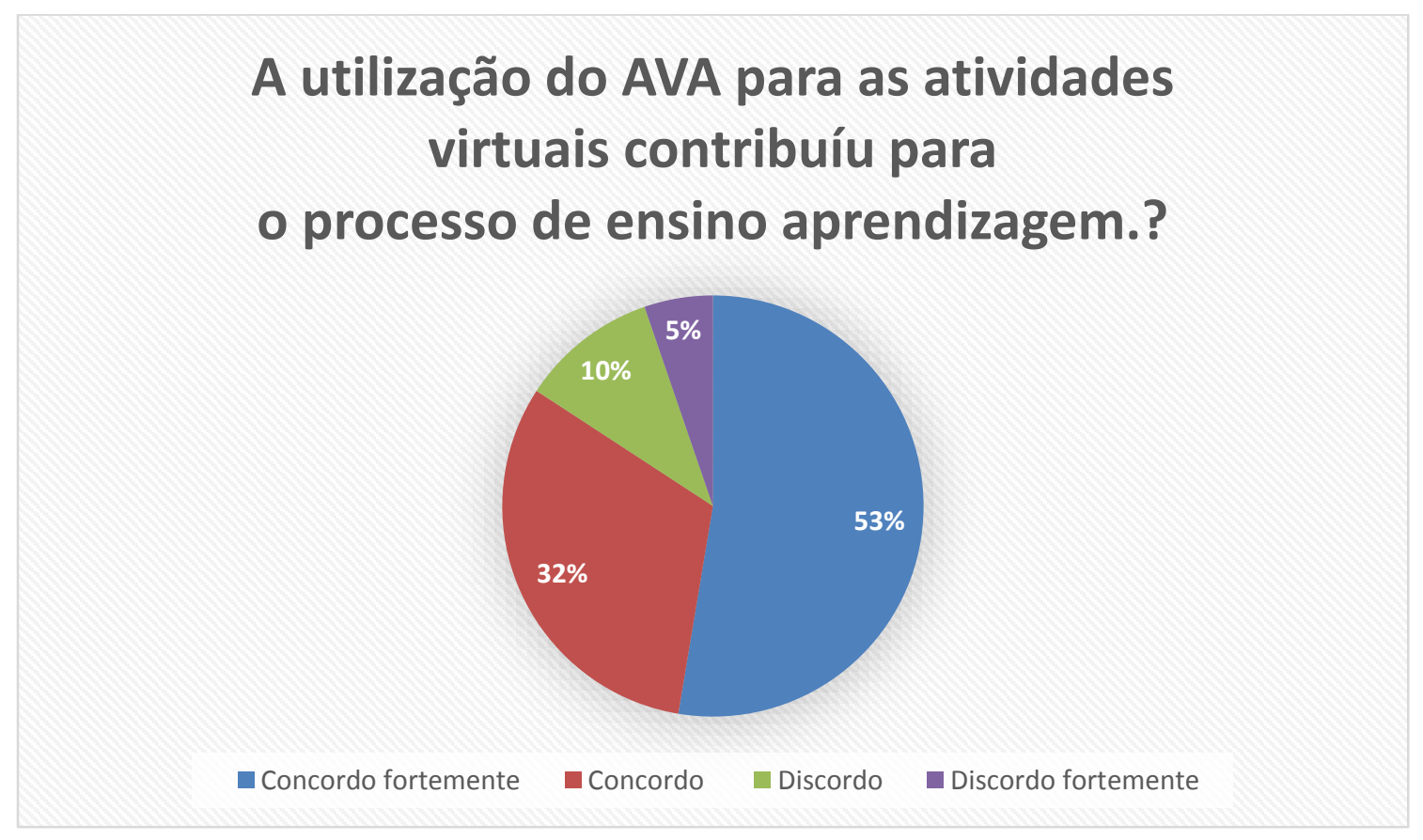

Figura 6.7: Utilização do AVA para as atividades virtuais

Através dos resultados demonstrados $85 \%$ dos alunos concordam com a utilização do AVA como auxílio no desenvolvimento das atividades do projeto. Ressalta-se que os $15 \%$ dos resultados negativos são correspondentes a 3 alunos de uma turma de 20 alunos.

\section{CONCLUSÃO}

Ao finalizar esta dissertação, é fundamental entender que a experiência de se aplicar um modelo Híbrido de Aprendizagem utilizando a Plataforma Arduino ao ensino Tecnológico de Informática não se propõe a ser uma solução para as dificuldades e problemas inerentes ao ensino tecnológico de Informática. A experiência apenas constata que o aprendizado pode se tornar mais atraente e motivador em função da maneira pela qual o assunto é abordado.

O desenvolvimento dos projetos proporcionou aos alunos o espírito de colaboração e trabalho em equipe. Através das atividades virtuais os alunos começaram a observar a internet 
como propiciadora de possibilidades para a sua própria aprendizagem, além da interação e colaboração.

A mistura da aprendizagem virtual com a presencial despertou nos alunos e orientadores uma nova forma de ensinar e aprender com colaboração e participação de todos na construção do conhecimento.

Para verificar o rendimento escolar entre os alunos que participaram do experimento, foram analisadas as notas da turma 2013 ( $2^{\circ}$ ano), e as notas da mesma turma em 2014 ( $3^{\circ}$ ano). Através dessa analise pode observar que as notas dos alunos aumentaram.

Com relação às novas habilidades e competências, os professores afirmam que os alunos tiveram mais recursos de expressividade, forçando-os a serem mais críticos e proativos. Com relação aos projetos, considera-se como uma nova alavanca para um universo escolar em que a programação não é habitual. A motivação é essencial para a disciplina de programação. Os projetos propiciaram aos alunos envolvimento, vivência, criticidade e desenvolvimento das habilidades técnicas e não técnicas.

Além disso, deve ser observada que, alunos e professores se deparam pela primeira vez com uma nova proposta de aprendizado, esta inovação dentro do universo do IFNMG, Campus Arinos levou a tomadas de decisão que posteriormente mostrou-se pouco prático.

Dentro desse contexto vale ressalta os seguintes pontos.

Planejamento: com a experiência adquirida fica claro a necessidade do relacionamento com outras disciplinas correlatas. Na utilização da plataforma Arduino, muitas vezes foi necessário interromper o projeto, para buscar conhecimento em outra disciplina, como Circuito e Física. Para uma nova edição, o planejamento adequado terá que interagir om as disciplinas de Circuito e Física.

Utilização das ferramentas virtuais: A experiência mostra que a aplicação de uma nova metodologia com apoio da tecnologia da informação, não tem força suficiente para modificar a relação aluno - professor. Somente a tomada de consciência do corpo docente, da necessidade de transformar o aprendizado em uma atividade colaborativa, permitirá a verdadeira transformação da relação aluno-professor em benefício da inovação e criatividade.

Avaliação da Aprendizado: Esse ao nosso entender foi o ponto mais delicado do projeto, embora tenhamos estruturado o conteúdo da disciplina de maneira diferenciada, nos deparamos com a dificuldade de avaliar o aprendizado de maneira compatível com o novo método utilizado. 
Em relação a proposta desta dissertação, conclui-se que ocorreu um dos momentos, dos muitos vividos na pesquisa, mais marcantes e que ratificou o valor e a importância de se trabalhar projetos educacionais, juntamente com alunos, e mostra-los a importância do papel representado por eles para o desenvolvimento. Os alunos demonstraram interesse em conhecer a plataforma Arduino e utiliza-la na disciplina de programação WEB. 
Como sugestões para trabalhos futuros propõe-se desenvolver um projeto educacional de robótica dentro da disciplina de programação do curso Técnico em Informática do IFNMG, Campus Arinos, visando a instituir um campeonato de robótica como forma motivadora dos alunos. Inserir novas ferramentas tecnológicas que facilitem ainda mais a participação e mobilidade dos alunos. E finalmente compartilhar e dissimilar com todos os Institutos Federais a metodologia colaborativa aplicada na disciplina de $W E B$. 


\section{REFERÊNCIAS}

[1] ELIA, M. O Papel do professor diante das inovações tecnológicas. 2008. Disponível em: <www.br-ie.org/pub/index.php/wie/article/view/980/966>. Acesso em: março. 2015.

[2] VALENTE, José A. Diferentes usos do computador na educação. In: Diferentes usos do computador na educação. $O$ uso inteligente do computador na educação. Palestra realizada em Belo Horizonte em 28 jan. 1998

[3] CÍCERO, Márcia Jani, ABDALLA JUNIOR, Humberto, GARROSSINI, Daniela Fávaro. A Metodologia Blended Learning no Ensino Tecnológico de Informática para a Disciplina de Metodologia de Desenvolvimento de Sistemas. INTERTECH'2012 - XII International Conference on Engineering and Technology Education, Dili, EAST TIMOR, 2012.

[4] BZUNECK, J.A. A Motivação do Aluno: Aspectos Introdutórios. In: BZUNECK, J.A.; BORUCHOVITCH, E. (Orgs). A motivação do aluno: contribuições da pscicologia contemporânea. Rio de Janeiro: Vozes, 2001.

[5] FONSECA, Celso Suckow. História do Ensino Industrial no Brasil. Rio de Janeiro: Escola Técnica. 1961.

[6] MEC, Centenário da Rede Federal de Educação Profissional e Tecnológica. Brasília, 2009. Disponível em: http:/portal.mec.gov.br/setec/arquivos/centenário

[7] GARCIA, Sandra Regina de Oliveira. “O fio da história: a gênese da formação profissional no Brasil”. In: Trabalho e Crítica. São Leopoldo: Ed. UNISINOS, 2000.

[8] Brasil. Lei n. 11.892 de 29 de dezembro de 2008. Institui a Rede Federal de Educação Profissional, Científica e Tecnológica, cria os Institutos

Educação, Ciência e Tecnologia, e dá outras providências. Diário Oficial da República Federativa do Brasil. 30 de dezembro de 2008. 
[9] IFNMG. Plano de Desenvolvimento Institucional (PDI). Diretoria de Extensão do Instituto Federal de Educação, Ciência e Tecnologia do Norte de Minas Gerais (IFNMG). Minas Gerais; 2009-2013.

[10] CENSO DEMOGRÁFICO 2010. Características gerais da população, religião e pessoas com deficiência. Rio de Janeiro: IBGE, 2012. Disponível em < ftp:/ftp.ibge.gov.br/censos/censos_demorafico_2010/características_Gerais. Acesso em: março de 2014

[11] REBELO, Rosana Aparecida Argento. O diálogo como prática pedagógica contribuindo para a superação da indisciplina escolar. In: FREIRE, Ana Maria Araújo (Org.). A pedagogia da libertação em Paulo Freire. São Paulo: Unesp, 2001.

[12] OLIVEIRA, Cacilda Lages. Significado e contribuições da afetividade, no contexto da Metodologia de Projetos, na Educação Básica. Dissertação (Mestrado em Educação Tecnológica), Centro Federal de Educação Tecnológica de Minas Gerais/CEFETMG, Belo Horizonte, 2006.

[13] FUKS, Hugo; PIMENTEL, Mariano Gomes; GEROSA, Marco Aurélio; FERNANDES e Maria Cristina Pfeiffer; LUCENA, Carlos José Pereira. Novas Estratégias de Avaliação Online: aplicações e implicações em um curso totalmente a distância através do ambiente AulaNet. In Avaliação da Aprendizagem em Educação Online. Orgs. Marco Silva e Edméa Santos. 2006. São Paulo: Loyola (pp.369-385). 98

[14] DILLENBOURG, P. What do you mean by collaborative learning?. In: DILLENBOURG, P. (Ed.). Collaborative-learning: Cognitive and Computational Approaches. Oxford: Elsevier, 1999.

[15] MORRIS, T. E se Aristóteles dirigisse a General Motors?: a nova alma das organizações. Trad. Ana Beatriz Rodrigues; Priscilla Martins Celeste. Rio de Janeiro: Elsevier, 2004.

[16] D’ELORS, Jacques (org). Educação: um tesouro a descobrir. Relatório para a UNESCO da Comissão Internacional sobre Educação para o Século XXI. São Paulo, Cortez, 1998, Cap. 4. 
[17] LIMA, Adriana Flávia Santos de Oliveira. Pré-escola e alfabetização. Vozes, $11^{\mathrm{a}}$ edição, Petrópolis - RJ, 1986.

[18] FRANCO, Sérgio Roberto Kieling; O construtivismo e a educação, Editora Mediação, $6^{\mathrm{a}}$ edição, Porto Alegre, 1997.

[19] VALASKI, S. A aprendizagem colaborativa com uso de computadores: uma proposta para a prática pedagógica. Curitiba, 2003.107 f. Dissertação (Mestrado em Educação) - Setor de Ciências Humanas e Teologia, Pontifícia Universidade Católica do Paraná.

[20] VYGOTSKY, L.S. Pensamento e Linguagem. Rio de Janeiro: Martins Fontes, 1998.

[21] VYGOTSKY, L.S. A formação social da mente. Rio de Janeiro: Martins Fontes, 1996

[22] MATOS, Rodrigo Antônio, Teoria do Construtivista. Disponível em: http://pt.pboulo.com/teoria-construtivista-59421.html. Acesso em 10/02/2015.

[23] FINO, Carlos Nogueira (2004), Construtivismo \& Construcionismo, disponível em: http://www3.uma.pt/carlosfino/Documentos/PowerPoint_Piaget-Papert.pdf, acesso em: julho de 2015.

[24] FERRAZ, Ana Paula do Carmo Marcheti; BELHOT, Renato Vairo. Taxonomia de Bloom: revisão teórica e apresentação das adequações do instrumento para definição de objetivos instrucionais. Gest. Prod., São Carlos.

[25] De Deus, M. A. ,Patricio dos Santos Jr., M ,Andrade Filho, M. Moacir, Gomes, José, Abdalla, H., ESTRUTURAÇÃO DE DISCIPLINA NA ÁREA DE TELECOMUNICAÇÕES COM BASE EM BLENDED LEARNING, XXXIX COBENGE 2011, Blumenau, Santa Catarina, outubro 2011

[26] AYCOCK, A., GARNAHAM, C., KALETA, R. Lessons learned from the hybrid course project. Teaching with Technology Today. University of Wisconsin-Milwaukee, 2002. 
[27] MCROBERTS, Michael. ArduinoBásico. (2011).

[28] Arduino, Plataforma Arduino, disponível em https://www.arduino.cc Acesso: em setembro de 2013.

[29] PINTO, Andrio dos Santos. Práticas de Ensino em Informática Educativa. 2011

[30] GOMES, Silvane Guimarães Silva. Reflexão sobre o perfil do aluno como determinante para a motivação e aprendizagem em cursos ead .2013

[31] SILVA, Simone Vasconcelos; LOPES, Arilise Moraes de Almeida; RIBEIRO, Leonardo da Silva. Reforço ao Ensino Presencial Utilizando o ambiente Colaborativo de Aprendizagem Moodle no Curso de Engenharia de Produção do Isecensa, Perspectivas on-line - Volume 5, 2008.

[32] SERAFIM, Luiz. O poder da inovação. Ed Saraiva, São Paulo, 2008.

[33] MAZZOCO, B. Um guia para escolher bem. Nova Escola, São Paulo, ano 30, n.280, p. 22-29, março.2015

[34] GIL, J.C. Como elaborar projetos de pesquisa. 4. Ed. São Paulo: Atlas, 2009

[35] Brasil. Ministério da Educação. Parecer CEB n. 16/99. Diretrizes Curriculares Nacionais para a Educação Profissional de Nível Técnico. Brasília, 1999. Disponível em:< http:// www.portal.mec.gov.br>. Acessado em: 15/08/2014.

[36] Brasil. Lei n. 9.394, de 20 de dezembro de 1996. Estabelece as diretrizes e bases da educação nacional. Brasília; 1996. Disponível em: 〈http://www.portal.mec.gov.br>. Acessado em: 16/08/2014.

[37] IFNMG. Plano de Curso Técnico Integrado ao Ensino Médio em Informática. Instituto Federal de Educação, Ciência e Tecnologia do Norte de Minas Gerais. Arinos, 2014. 
[38] GADOTTI, Moacir. Perspectivas atuais da educação. Porto Alegre, Ed. Artes Médicas, 2000

[39] VASCONCELOS, Celso dos Santos. Construção do conhecimento em sala de aula. São Paulo : Libertad, 1995.

[40] THOMAS, John W. A Review of Research on Project-based Learning. Relatório técnico. Autodesk Foundation, 2000. Disponível em: < http://173.226.50.98/sites/default/files/news/(PROJECT BASED LEARNING) (Project Based Learning)_research2.pdf.>. Acessado em: 24/09/2014.

[41] VAGARINHO, João Paulo Teles. E-learning: Estudo sobre as componentes mais usadas pelos intervenientes. Dissertação (Mestrado em Comércio Eletrônico e Internet), Universidade Aberta, Lisboa - Portugal, 2011. Disponível em: <http://repositorioaberto.uab.pt/handle/10400.2/1875>. Acessado em: 24/02/2015. 


\section{ANEXOS}

ANEXO A - TRAJETÓRIA DA EDUCAÇÃO FEDERAL E TECNOLÓGICA NO BRASIL

Rede Federal de Profissional e Tecnológica no Brasil

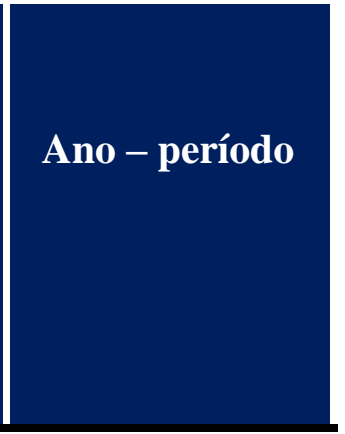

- Instituída oficialmente a educação profissional brasileira através do DECRETO No 7.566, DE 23 DE SETEMBRO DE 1909, sancionado pelo então Presidente da República Nilo Peçanha.

1909

- Criação de 19 Escolas de Aprendizes Artífices, com o intuito de preparar próximas gerações para o mercado produtivo, dominado até então pela burguesia emergente.

- O ensino profissional foi delegado ao Ministério de Indústria e Comércio.

- Através do Decreto ${ }^{\circ} 8.319$, de 23 de outubro, fez-se a primeira regulamentação do ensino agrícola no País, em todos seus graus e modalidades.

- Nilo Peçanha, em 1910, instalou dezenove "Escolas de Aprendizes Artífices" destinadas "aos pobres e humildes", distribuídas em várias Unidades da Federação. 
- Reorganização do ensino agrícola no País, objetivando formar chefes de cultura, administradores e capatazes.

- O Congresso Nacional sanciona o Projeto de Fidélis Reis, que prevê o oferecimento obrigatório do ensino profissional no país.

- A existência das escolas públicas profissionalizantes, de forma explícita, vai ao encontro dos interesses do capital industrial, segundo o novo modelo de desenvolvimento.

- A partir de 1942, as Escolas de Aprendizes Artífices são 1930 a 1945 transformadas em Escolas Industriais e Técnicas e com isso passam a oferecer a formação profissional em nível equivalente ao secundário.

- Os anos de 1956 a 1961 imprimem a marca do aprofundamento da relação entre Estado e economia, os investimentos em educação priorizam a formação de profissionais orientados para as metas de desenvolvimento do país.

- No ano de 1959 houve o processo de transformação das Escolas Industriais e Técnicas em autarquias.

- As instituições ganham autonomia didática e de gestão e passam a ser denominadas Escolas Técnicas Federais, assim intensificando a formação de técnicos.

- Em 1971, é transformado, de maneira compulsória, todo currículo do segundo grau em técnico - profissional.

- Em 1978, três Escolas Técnicas Federais (Paraná, Minas Gerais e Rio de Janeiro) são transformadas em Centros Federais de Educação Tecnológica, podendo formar 1978 engenheiros de operação e tecnólogos. 
- No ano de 1994, a Lei Federal no 8.984 institui no país o Sistema Nacional de Educação Tecnológica.

- Transformação das Escolas Técnicas Federais em CEFETs (Centros Federais de Educação Tecnológica).

- Em 1996, a Lei de Diretrizes e Bases da Educação Brasileira, no 9.394, é aprovada e, no ano seguinte, o Decreto $n^{\circ} 2.208$ regulamenta os artigos da nova LDB que 1996 tratam especificamente da educação profissional.

- O Decreto 2.208 regulamenta a educação profissional e cria o PROEP (Programa de Expansão da Educação Profissional).

- Substituição do Decreto $\mathrm{n}^{\circ} 2.208 / 97$ pelo Decreto $\mathrm{n}^{\circ}$ 5.154/04, que elimina as amarras estabelecidas por aquele, que se traduziam numa série de restrições na organização curricular e pedagógica e na oferta dos cursos técnicos.

- As Escolas Agrotécnicas Federais recebem autorização excepcional para ofertar cursos superiores de tecnologia, em nível de graduação.

- Lei 11.195, expande a oferta da educação profissional preferencialmente ocorrendo em parceria com Estados, Municípios e Distrito Federal, setor produtivo ou organizações não governamentais.

- Lançada a primeira fase do Plano de Expansão da Rede Federal, com a construção de 60 novas unidades de ensino pelo Governo Federal.

- Instituí-se no âmbito federal, o Programa Nacional de Integração da Educação Profissional com a Educação de Jovens e Adultos. 
- Lançada a segunda fase do Plano de Expansão da Rede Federal.

- O Decreto 6.302 institui o Programa Brasil Profissionalizado.

- É lançado o Catálogo Nacional dos Cursos Técnicos.

- $\quad$ Em 29 de dezembro de 2008 é sancionada a lei $\mathrm{n}^{\circ} 11.892$ pela qual a Rede Federal de Educação Profissional, Científica e Tecnológica cria os Institutos Federais de 2008 Educação, Ciência e Tecnologia. 


\section{GERAIS}

\begin{tabular}{|c|c|}
\hline IFNMG & Ano \\
\hline - Criação da Escola de Iniciação Agrícola de Salinas & 1953 \\
\hline - Criação da Escola Agrotécnica de Januária & 1960 \\
\hline $\begin{array}{l}\text { • O CEFET Januária e a Escola Agrotécnica Federal de } \\
\text { Salinas se uniram e propuseram a criação do Instituto Federal do } \\
\text { Norte de Minas Gerais (IFNMG) }\end{array}$ & 2007 \\
\hline $\begin{array}{l}\text { - De acordo com a Lei } 11.892 \text {, de } 29 / 12 / 2008 \text {, foram } \\
\text { criados em todo o país } 38 \text { Institutos Federais de Educação } \\
\text { Ciência e Tecnologia, entre os quais o Instituto do Norte de } \\
\text { Minas Gerais. }\end{array}$ & 2008 \\
\hline $\begin{array}{l}\text { - A atuação do Campus Arinos iniciou-se em fevereiro } \\
\text { de } 2009 \\
\text { • Em Janeiro de 2009, o campus Araçuaí foi integrado } \\
\text { ao IFNMG }\end{array}$ & 2009 \\
\hline $\begin{array}{l}\text { • Em } 19 \text { de Janeiro de } 2010 \text { inauguração do Câmpus } \\
\text { Araçuai; } \\
\qquad \text { O Campus Montes Claros e o Campus Pirapora foram } \\
\text { autorizados a funcionar através da Portaria } \mathrm{n}^{\circ} 1.366 \text {, de } 06 \text { de } \\
\text { dezembro de } 2010 \text {. }\end{array}$ & 2010 \\
\hline
\end{tabular}


- O Instituto Federal do Norte de Minas Gerais

(IFNMG) foi contemplado com duas novas unidades, Campus Diamantina e Campus Teófilo Otoni.

- Janaúba foi selecionada pela Secretaria de Educação

Profissional e Tecnológica (Setec) do MEC para receber a

Unidade de Educação Profissional (UEP) do IFNMG.

- Portaria $n^{\circ}$ 27, de 21 de Janeiro de 2015, o IFNMG

foi autorizado a promover o funcionamento dos

Campus avançado Janaúba.

2015

- Aula Inaugural da unidade Teófilo Otoni e do

Campus avançado de Janaúba

- Porteirinha sediará um Campus Avançado do IFNMG 

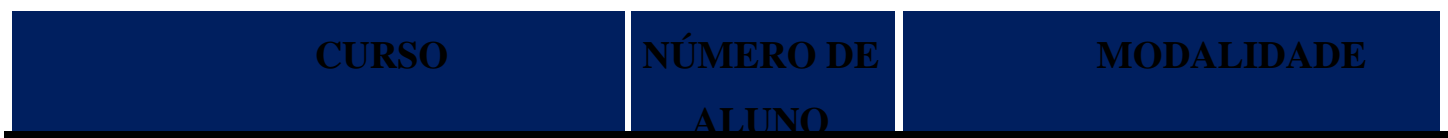

Técnico em Administração

CONCOMITANTE

/SUBSEQUENTE

Técnico em Informática

CONCOMITANTE

/SUBSEQUENTE

Técnico em Agropecuária

155

INTEGRADO

Técnico em Informática

134

Bacharelado em Administração

110

Bacharelado em Agronomia

Tecnologia em Gestão Ambiental

Tecnologia em Produção de Grãos

\begin{tabular}{|l|}
\hline 83 \\
\hline 78 \\
\hline 26 \\
\hline
\end{tabular}

Técnico em Administração

Técnico em Serviços Públicos

41

INTEGRADO

INTEGRADO

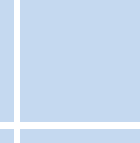

Técnico em Segurança do Trabalho

Técnico em Segurança do Trabalho

\begin{tabular}{|l|}
\hline 41 \\
\hline 31 \\
\hline
\end{tabular}

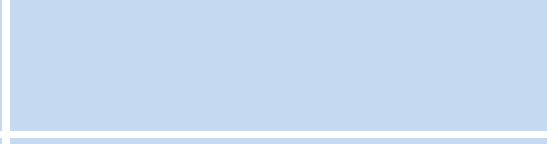

\begin{tabular}{|l|l|}
\hline 77 \\
\hline
\end{tabular}

Técnico em Logística

Técnico em Meio Ambiente

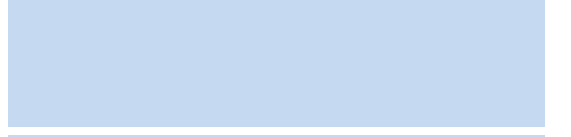

Técnico em Informática para Internet

Técnico em Secretariado

\begin{tabular}{|c|c|}
\hline 18 & E-TEC \\
\hline 15 & E-TEC \\
\hline 11 & E-TEC \\
\hline 11 & E-TEC \\
\hline
\end{tabular}




\begin{tabular}{|c|c|c|}
\hline Técnico em Multimeios Didáticos & 51 & E-TEC \\
\hline Técnico em Secretaria Escolar & 80 & E-TEC \\
\hline Técnico em Agente C. de Saúde & 50 & E-TEC \\
\hline Técnico em Transações Imobiliárias & 12 & E-TEC \\
\hline Técnico Hotelaria e Hospedagem & 10 & E-TEC \\
\hline PROEJA & 20 & E-TEC \\
\hline Técnico em Agropecuária & & \\
\hline Mulheres Mil & 35 & PRONATEC \\
\hline
\end{tabular}


ANEXO D - OS PRINCIPAIS MODELOS OFICIAIS DA PLATAFORMA ARDUINO

\begin{tabular}{|c|c|c|c|c|c|c|c|c|}
\hline & $\begin{array}{l}\text { Arduino } \\
\text { Uno }\end{array}$ & $\begin{array}{c}\text { Arduino } \\
\text { Mega2560 }\end{array}$ & $\begin{array}{l}\text { Arduino } \\
\text { Leonardo }\end{array}$ & $\begin{array}{l}\text { Arduino } \\
\text { Due }\end{array}$ & $\begin{array}{l}\text { Arduino } \\
\text { ADK }\end{array}$ & $\begin{array}{l}\text { Arduino } \\
\text { Nano }\end{array}$ & $\begin{array}{c}\text { Arduino Pro } \\
\text { Mini }\end{array}$ & $\begin{array}{l}\text { Arduino } \\
\text { Esplora }\end{array}$ \\
\hline Microcontrolador & ATmega328 & ATmega2560 & ATmega32u4 & AT91SAM3X8E & ATmega2560 & $\begin{array}{c}\text { ATmega168 } \\
\text { (versão 2.x) ou } \\
\text { ATmega328 } \\
\text { (versão 3.x) }\end{array}$ & ATmega168 & ATmega32u4 \\
\hline Portas digitais & 14 & 54 & 20 & 54 & 54 & 14 & 14 & - \\
\hline Portas PWM & 6 & 15 & 7 & 12 & 15 & 6 & 6 & - \\
\hline Portas analógicas & 6 & 16 & 12 & 12 & 16 & 8 & 8 & - \\
\hline Memória & $\begin{array}{l}32 \mathrm{~K}(0,5 \mathrm{~K} \text { usado } \\
\text { pelo bootloader) }\end{array}$ & $\begin{array}{l}256 \mathrm{~K} \text { (8 K usados } \\
\text { pelo bootloader) }\end{array}$ & $\begin{array}{l}32 \mathrm{~K} \text { ( } 4 \mathrm{~K} \text { usados } \\
\text { pelo bootloader) }\end{array}$ & $\begin{array}{l}512 \mathrm{~K} \text { disponivel } \\
\text { para aplicações }\end{array}$ & $\begin{array}{l}256 \mathrm{~K} \text { (8 K usados } \\
\text { pelo bootloader) }\end{array}$ & $\begin{array}{c}16 \mathrm{~K} \text { (ATmega168) } \\
\text { ou 32K } \\
\text { (ATmega328), } 2 \mathrm{~K} \\
\text { usados pelo } \\
\text { bootloader }\end{array}$ & $\begin{array}{c}16 \mathrm{~K} \text { (2k usados } \\
\text { pelo bootloader) }\end{array}$ & $\begin{array}{c}32 \mathrm{~K} \text { (4 Kusados } \\
\text { pelo } \\
\text { bootloader) }\end{array}$ \\
\hline Clock & $16 \mathrm{Mhz}$ & $16 \mathrm{Mhz}$ & $16 \mathrm{Mhz}$ & $84 \mathrm{Mhz}$ & $16 \mathrm{Mhz}$ & $16 \mathrm{Mhz}$ & $\begin{array}{c}8 \mathrm{Mhz} \text { (modelo } \\
3.3 \mathrm{v} \text { ) ou } 16 \mathrm{Mhz} \\
\text { (modelo } 5 \mathrm{v} \text { ) }\end{array}$ & $16 \mathrm{Mhz}$ \\
\hline Conexão & USB & USB & Micro USB & Micro USB & USB & USB Mini-B & $\begin{array}{c}\text { Serial / Módulo } \\
\text { USB externo }\end{array}$ & Micro USB \\
\hline $\begin{array}{c}\text { Conector para } \\
\text { alimentação } \\
\text { externa }\end{array}$ & Sim & Sim & Sim & Sim & Sim & Não & Não & Não \\
\hline $\begin{array}{l}\text { Tensão de } \\
\text { operação }\end{array}$ & $5 v$ & $5 v$ & $5 v$ & $3.3 \mathrm{v}$ & $5 v$ & $5 v$ & $\begin{array}{c}3.3 \mathrm{v} \text { ou } 5 \mathrm{v}, \\
\text { dependendo do } \\
\text { modelo }\end{array}$ & $5 v$ \\
\hline $\begin{array}{c}\text { Corrente máxima } \\
\text { portas } E / S\end{array}$ & $40 \mathrm{~mA}$ & $40 \mathrm{~mA}$ & $40 \mathrm{~mA}$ & $130 \mathrm{~mA}$ & $40 \mathrm{~mA}$ & $40 \mathrm{~mA}$ & $40 \mathrm{~mA}$ & - \\
\hline Alimentação & $7-12 \mathrm{Vdc}$ & $7-12 \mathrm{Vdc}$ & $7-12 \mathrm{Vdc}$ & $7-12 \mathrm{Vdc}$ & $7-12 \mathrm{Vdc}$ & $7-12 \mathrm{Vdc}$ & $\begin{array}{c}3.35-12 \mathrm{~V} \\
\text { (modelo } 3.3 \mathrm{v}) \text {, ou } \\
5-12 \mathrm{~V} \text { (modelo } \\
5 \mathrm{v})\end{array}$ & $5 v$ \\
\hline
\end{tabular}




\section{ANEXO E - FORMULÁRIO DE AVALIAÇÃO DA DISCIPLINA: WEB II}

Esse questionário tem por objetivo coletar as opiniões dos alunos sobre os aspectos da disciplina Web II e sobre sua auto avaliação. Os resultados buscam um reflexão sobre o trabalho em equipe e o formato da disciplina, de forma que favoreça futuramente. Analise cada questão relacionada a seguir e assinale o conceito que mais se aproxima da sua opinião, onde o 4 Concorda Fortemente (excelente), 3 Concorda (bom), 2 Discordo (ruim) e o 1 Discordo Fortemente (péssimo).

\section{AVALIAÇÃO DE ASPECTOS RELACIONADOS AO MODELO DOS}

OBJETOS

\begin{tabular}{l|l|l|l|}
1 & 2 & 3 & 4
\end{tabular}

1. Os objetivos da disciplina ficaram claros.

2. As aulas teóricas foram bem estruturadas e estimulantes.

3. Os tópicos foram apresentados de forma clara e compreensível

4. O método de trabalho em grupo foi adeauado.

5. A carga horária da disciplina foi eficaz para o desenvolvimento

6. O professor estimulou o interesse dos alunos

7. O professor proporcionou o tempo oportuno para o desenvolvimento das atividades.

8. Houve espaços para diálogos com o professor

9. Houve apoio de outros professores durante o desenvolvimento do trabalho.

10. A disciplina foi relevante para o seu aprendizado.

11. O método de avaliação foi claro 
12. O método de avaliação permite uma melhor compreensão do conteúdo da disciplina

13. Gostou de frequentar a disciplina.

14. Aplicação da plataforma Arduino contribuiu para uma maior motivação e sucesso dos alunos na disciplina.

AVALIAÇÃO DA EQUIPE

1. Todos os integrantes sabiam quais eram suas funções.

2. Os professores reorientaram os erros cometidos durante o desenvolvimento do projeto.

3. O grupo se manteve unido mesmo com dificuldade no projeto.

4. O grupo manteve encontros semanal

5. Todos trouxeram sua colaboração às tarefas que eram comuns.

6. O ambiente do grupo era informal

7. As relações entre os membros dos grupos eram cooperativas.

8. O papel do líder foi importante ao grupo.

9. Todos os membros do grupo participaram do planejamento.

10. O grupo cumpriu a jornada de trabalho pré-estabelecida

11. O grupo comprometeu-se com a qualidade do trabalho.

12. O grupo foi acompanhado por professores especialistas no assunto do projeto.

13. O desenvolvimento do projeto proporcionou as capacidades de relacionar em equipe, analisar, elaborar e planejar. 
1. Você interagiu com os demais membros do grupo, soube respeitar posições contrárias e soube escutar.

2. Assumiu decisões dentro de seus limites, não comprometendo o andamento do trabalho.

3. Realizou suas tarefas de forma completa

4. Ficou motivado em trabalhar em equipe

5. Sua motivação foi continua.

6. Teve interesse, entusiasmo e determinação na execução de suas atividades.

7 A disciplina contribuiu em mantes o seu interesse pelo curso. 